\title{
CLASSIFICATION AND DISTRIBUTION OF SOUTH ATLANTIC RECENT POLYCYSTINE RADIOLARIA ${ }^{1}$
}

\author{
Demetrio Boltovskoy
}

\begin{abstract}
This paper presents a review of the current knowledge on the identification and distribution of Recent polycystine Radiolaria so far recorded, or presumed to occur, in the South Atlantic Ocean $\left(0^{\circ}\right.$ to $60^{\circ} \mathrm{S}$, from the South American coasts to the coasts of Africa). However, because the area concerned covers from equatorial to Antarctic waters, and since polycystine radiolarians are geographically (but not environmentally) cosmopolitan, the review covers most common species worldwide. Illustrations, short diagnoses, bibliographic references and distributional data (both geographic and vertical) are included for 164 polycystine morphotypes (species-groups, species, and subspecific categories). Introductory remarks offer general data on radiolarian anatomy, biology, ecology, and reproduction. Methodological aspects are dealt with in some detail, with special emphasis being placed on comparative aspects of the environmental and paleoenvironmental information conveyed by planktonic materials, sediment trap samples, and sedimentary deposits. Known or assumed geographic and vertical species-specific distribution ranges are summarized, as well as available information on absolute abundances in the water-column (plankton and sediment trap samples) and in the surface sediments. The illustrated glossary aimed at the less experienced student defines the terms and morphological details useful for diagnostic purposes.
\end{abstract}

Demetrio Boltovskoy, Departamento de Ciencias Biológicas, Facultad de Ciencias Exactas y Naturales, Universidad de Buenos Aires, 1428, Buenos Aires, Museo Argentino de Ciencias Naturales "Bernardino Rivadavia", and CONICET, Argentina

KEYWORDS: Radiolaria, Polycystina, identification, distribution, Recent, plankton, review

${ }^{1}$ This article constitutes a modified version of the chapter "Radiolaria Polycystina", originally prepared for the book "South Atlantic Zooplankton" (D. Boltovskoy, ed.), a ca. 2,000 pages guide on the identification and distribution of 30 zooplanktonic groups to be published in 1999 by Backhuys Publishers, The Netherlands.

1 August 1998

Submission: 31 August 1997, Acceptance: 15 April 1998

http://palaeo-electronica.org/1998 2/boltovskoy/issue2.htm

\section{INTRODUCTION}

Polycystine radiolarians are exclusively marine, pelagic, solitary or colonial protists provided with actinopods. Polycystines comprise the Collodaria, a small group lacking a 
skeleton, or provided only with scattered mono- or polyaxonic spicules; and the Spumellaria and Nassellaria, most of which have a well developed siliceous latticed or spongy skeleton (see "Sedimentary vs. water-column materials."). Solitary species (the greatest majority) range between $20-30 \mu \mathrm{m}$ to about $300 \mu \mathrm{m}$, but colonies (some Collodaria and the spumellarian family Collosphaeridae) may in exceptional cases be as long as $3 \mathrm{~m}$ (Swanberg 1979). The siliceous skeletons of the polycystines are a major contributor to the sedimentary flux, their earliest records dating back to the Cambrian. Paleozoic, Mesozoic and Cenozoic sequences furnish detailed records for evolutionary, stratigraphic and paleoecologic analyses.

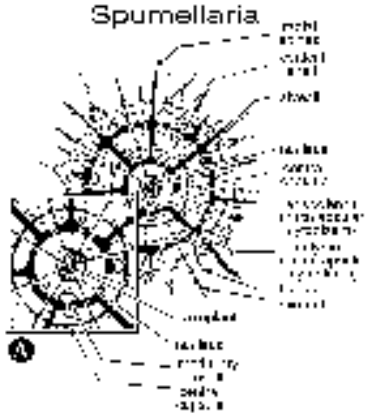

Figure $1 A$.

A distinguishing feature of all radiolarians (polycystines and phaeodarians) is the central capsule, a proteinaceous perforated membrane that divides the cytoplasm into two areas: the endoplasm or intracapsular cytoplasm, and the calymma or extracapsular cytoplasm (Figure 1A).

This central capsule is either spherical (in many Spumellaria), or elongated and pyriform (in most Nassellaria, Figure 1B). The intracapsular cytoplasm contains reserve substances and major cytoplasmic organelles (nucleus or nuclei, mitochondria, and other organelles, except for the digestive vacuoles), and is generally believed to be responsible for the functions of reproduction, biochemical synthesis and energy production. The calymma is the frothy or

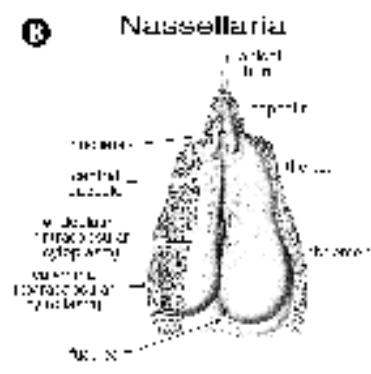

Figure 1B. web-like extracapsular cytoplasm where the digestive vacuoles are located. Algal symbionts, when present, are enclosed within vacuoles usually located in the calymma. Colonial forms have a gelatinous sheath containing numerous central capsules interconnected by a rhizopodial network.

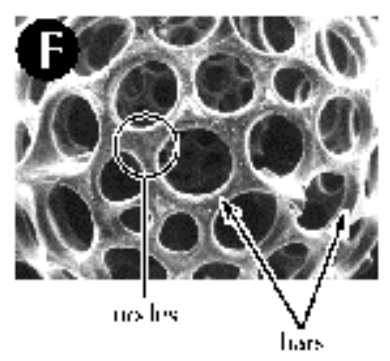

Figure 2F.

Polycystine skeletons are typically constructed of a network of structures which can be either connected at both ends with other elements - the bars (Figure 2F), or formations attached to the rest of the shell by one end only - the spines (Figure 2A-B, 2G). All skeletal elements are composed of amorphous silica $\left(\mathrm{SiO}_{2} \mathrm{nH}_{2} \mathrm{O}\right)$. There is a perplexing variety of shapes in which these bars and spines can be arranged in order to form the skeleton, from simple latticed spheres or a few anastomosed spines (Figure 15.119), to elaborate constructions with several concentric spheres (Figure 2B) or multilocular conical structures with protruding latticed or solid appendages known as wings, feet, teeth, etc. (Figure 3O-P, and 3Q-R). 
Very little is known about the reproduction of the Radiolaria. In addition to vegetative reproduction (Hollande and Enjumet 1953), the production of biflagellated swarmers was observed, but it is not known if the swarmers are asexual dissemules or motile gametes (Anderson 1983a). Although no direct estimates have been made so far, it is generally assumed that individual radiolarian life spans are around

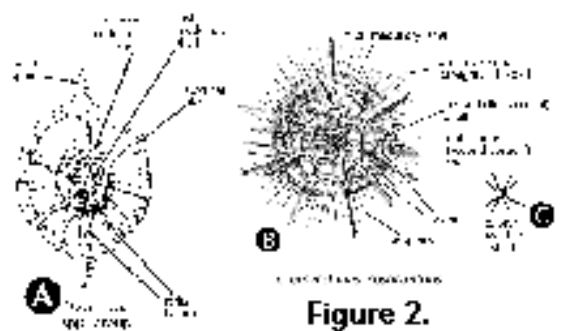
two to four weeks (Anderson 1983a; Caron and Swanberg 1990).

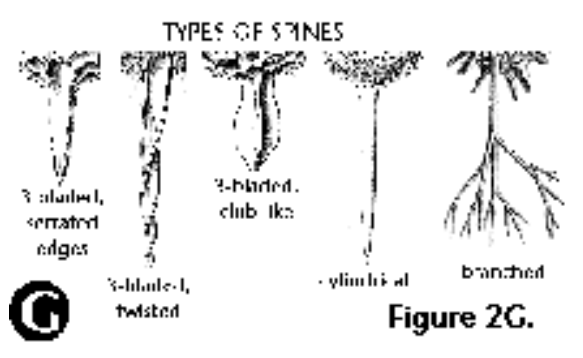

Polycystines consume a wide variety of prey including bacteria, algae, protists, copepods, appendicularians, and other small zooplankton (Anderson 1983a, 1993; Caron and Swanberg 1990). Algal symbionts, when present, secrete photosynthetic products that are assimilated by the host as a nutritional source

Figure 2G. (Anderson 1983b).

The first published descriptions of Radiolaria date back to the early nineteenth century. Between approximately 1850 and 1900, C. G. Ehrenberg, J. Müller, R. Hertwig, A. Popofsky, and especially E. Haeckel described thousands of new species and provided the first comprehensive classification systems (Riedel 1967a). After a period of little activity, interest in the Radiolaria was renewed around 1950, and somewhat later further fostered by the rich sedimentary materials recovered by the Deep Sea Drilling Project.

Because of their application to stratigraphy, polycystine studies have traditionally been within the realm of geologists/paleontologists, with biologically-oriented publications representing less than $10 \%$ of the overall total produced to date (A. Sanfilippo, personal commun., 1997). The directory included in the 1994 issue of Radiolaria (Newsletter for the International Association of Radiolarian Paleontologists) lists 400-plus names; however, only $100-150$ of these are primarily concerned

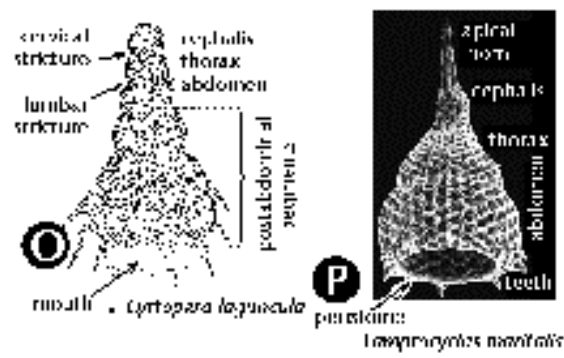

Figure 30-P. with radiolarian studies. 


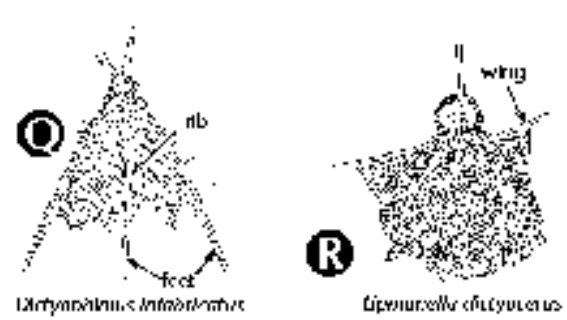

Figure 3Q-R.

Almost all these workers are geologists focusing their interest on stratigraphic and paleoceanographic problems, especially dealing with Paleozoic and Mesozoic deposits; interest in Cenozoic faunas has been dwindling over the last few years. Biologicallyoriented research based on samples from the watercolumn has even fewer specialists, and at present they are probably less than 10-20 world-wide. Since 1834 approximately 3500 works on polycystine radiolarians have been published (over half of these on Cenozoic faunas, about $35 \%$ on Mesozoic, and $15 \%$ on Paleozoic; A. Sanfilippo, personal commun., 1997).

\section{METHODS}

\section{Provenance and collection of materials}

Most of the surveys on extant polycystine radiolarians published to date are based on samples of their skeletons preserved in the surface sediments, rather than on plankton samples. Sediment samples have some advantages over water-column materials, but also several important shortcomings (see Sedimentary vs. water-column materials).

A variety of sediment coring and grabbing devices have been used throughout the years for analyses of the polycystines from the upper centimeters of the sediments (Kennett 1982). Gravity and Kasten corers are among the simplest, permitting retrieval of up to a few meters of sediment at a time from practically any depth. Piston corers have been used widely due to their ability to recover long sedimentary sequences, up to $20-30 \mathrm{~m}$ in length. However, all these devices tend to disturb the sediments, especially the uppermost layer which is of particular importance for the analysis of Recent assemblages. Box corers (rectangular, shallow, ca. $1 \mathrm{~m}$ coring boxes which ensure complete closure of water-flow passages after sampling and before leaving the seabed, thus minimizing sample washout during ascent) are preferable for retrieval of the top layer of the sediments. However, the fact that box core samples usually lack the thin uppermost phytodetrital film characteristic of most sediments (Billett et al. 1983) suggested that the bow-wave of the device is strong enough as to wash away any mobile particles before hitting the bottom. Multicorers, an arrangement of several short coring tubes mounted on a rigid frame seem to overcome this problem successfully as they have been shown to collect phytodetritus, as well as significantly higher numbers of macrobenthic specimens than box corers (Bett et al. 1994).

Plankton samples for radiolarian studies are usually collected with nets. However, this group, as well as a few other microzooplanktonic taxa, pose serious methodological difficulties. Indeed, they are too small (around 20-30 to $300 \mu \mathrm{m}$ ) to collect effectively with standard zooplanktonic nets (100 to $300 \mu \mathrm{m}$ in pore size), yet too scarce in most areas to yield adequate catches with water-bottles or low-powered pumps. Thus, fine- 
meshed nets have to be employed, which significantly complicates not only the concentration of the radiolarians (due to the concomitant retrieval of other organisms, some of which, like the diatoms, cannot be fractioned out later; see Swanberg and Eide 1992), but also because net clogging jeopardizes subsequent estimations of the volume of water filtered (Tranter and Smith 1968; Boltovskoy 1981b). In order to avoid clogging by smaller particles, thus ensuring better estimates of the volume of water filtered and larger sample-sizes, meshes ranging between 60 and up to $100 \mu \mathrm{m}$ are traditionally used for polycystine studies in the water-column. It should be stressed, however, that both absolute quantitative estimates of radiolarian abundance, and the proportions of at least some species and developmental stages may be seriously biased in these collections: Boltovskoy et al. (1993a) reported that in sediment trap materials from the tropical Atlantic shells below $40-60 \mu \mathrm{m}$ represent roughly $50 \%$ of the overall polycystine fauna.

Estimates of radiolarian abundances in the water-column must be performed with flowmetered nets; clogging of the meshes, in particular of those with small pores, makes assessment of the volume of water filtered based on distance towed and mouth diameter extremely unreliable (Tranter and Smith 1968; Boltovskoy 1981a, b). Thus, whenever unflowmetered nets are employed, such as those derived from Tucker's (1951) opening-closing mechanism (e.g., the Multinet, based on Bé's 1962, design; the MOCNESS, Wiebe et al. 1976; the RMT 1+8, Baker et al. 1973), it is strongly recommended that evaluation of radiolarian concentrations be avoided (species proportions, on the other hand, are in principle unaffected in these samples).

For assessment of the delicate colonial forms, as well as for studies of feeding, growth, metabolism, etc. of live individuals, specimens are collected by divers (e.g., Swanberg $\underline{1979}$ ), or by means of very short and slow plankton tows, thus ensuring a better preservation of the protists (Matsuoka 1992).

Sediment trap techniques have undergone major improvements in the last years, thus constituting a very useful tool for the collection of polycystine materials (US GOFS 1989; Lange and Boltovskoy 1995). Simple sediment traps consist of a concentrating cone or funnel which tapers into a collecting jar; the array, which can have either one or several traps, is moored to the bottom or drifts with the current suspended from a buoy at the surface. Time-series models are deployed at different oceanic locations for periods up to a year or more, and are provided with a mechanism which replaces the collecting cup at predetermined intervals thus yielding a detailed record of the changes in the amount and type of flux throughout several seasons (Honjo and Doherty 1988; Lange and Boltovskoy 1995).

Sediment-trap materials have some important advantages over planktonic collections. Sample-size is usually much larger in sediment traps than in plankton nets, with fluxes as high as 200,000 shells $/ \mathrm{m}^{2} /$ day having been recorded in the equatorial Atlantic (Boltovskoy et al. 1996; see also table 3 in Boltovskoy et al. 1993a). Seasonal plankton collections are composed of a sequence of snapshots which represent but an insignificant proportion of the total time elapsed between tows, and may therefore not 
only under- or overestimate mean protist abundances (e.g., Bé et al. 1985), but also yield "atypical" specific assemblages. Time-series sediment trap samples, on the other hand, integrate over preselected depth and time ranges, thus averaging the overlying plankton over restricted periods which yield adequate chronological resolution to allow pinpointing the relative importance of limited offsets of the yearly cycle. Furthermore, since seasonal variations in total mass flux are usually closely coupled with primary production in the upper mixed layer (Honjo et al. 1982, 1988; Deuser et al. 1983, 1990; Wefer 1989), comparison of total flux vs. radiolarian numbers and specific makeup can furnish first hand information on indicators (and paleoindicators) of the biological productivity of the associated water masses.

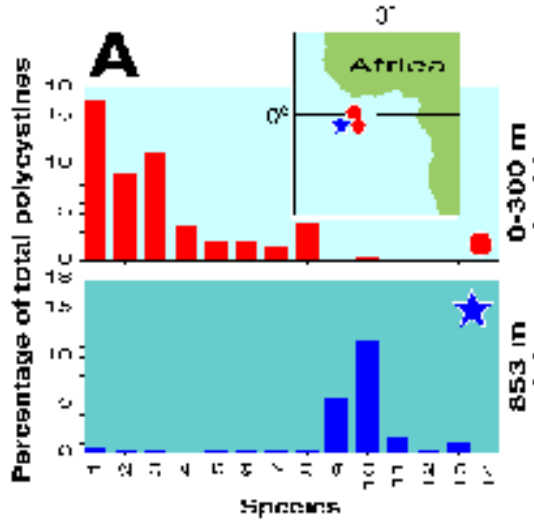

Figure 4A.

Sediment trap materials, however, also have some shortcomings. Because of limitations associated with the hydrodynamic properties of particle accumulation in the traps, these devices are most effective when deployed at depths in excess of 500-700 m (US GOFS 1989; Lange and Boltovskoy 1995). As a result, they integrate the flux from several biologically dissimilar layers (e.g., Kling 1979; Kling and Boltovskoy 1995). Furthermore, sinking skeletons intercepted at these depths may not adequately reflect their standing stocks at the surface, nor their specific composition. Boltovskoy and Alder (1992) concluded that, in the Weddell Sea, over $90 \%$ of the polycystines that inhabit the upper $400 \mathrm{~m}$ are destroyed (probably due to fragmentation by grazing) before reaching $400-900 \mathrm{~m}$ of depth.

Subsurface advection of shells produced at higher latitudes and integration of low protist abundances over large depth intervals may be responsible for the fact that, in the eastern equatorial Atlantic, polycystine assemblage compositions recorded in plankton samples at 0-300 $\mathrm{m}$ are totally different from those recovered in traps at 800-2000 m (Boltovskoy et al. 1995; Figure 4A, $\underline{4 B})$.

It should be borne in mind that the yields of sediment trap samples are not amenable to direct comparisons with those of plankton samples: while the former are an

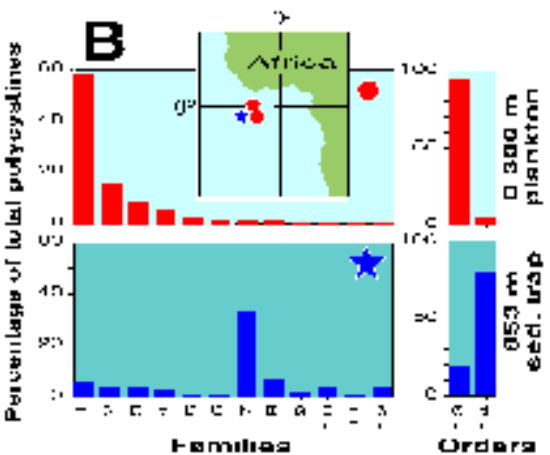

Figure 4B. expression of the downward flux, which in turn is associated with productivity and preservation, quantitative plankton samples give information on standing stock only. Hence, compositional differences may not only reflect advection, destruction by grazing, etc., but also biological traits of the species considered. Thus, a scarce species with high reproduction, mortality and output rates may be rare in the plankton but abundant 
in the underlying sediment trap (Kling and Boltovskoy 1995; Boltovskoy et al. 1995).

As with other zooplanktonic groups, analyses of radiolarian vertical distribution patterns are usually performed with the aid of vertically stratified plankton tows (e.g., Renz 1976; Kling 1979; Dworetzky and Morley 1987; Kling and Boltovskoy 1995; Abelmann and Gowing 1997). However, because their identification is based on the siliceous skeleton which preserves after the death of the cell, in order to discriminate live vs. dead protists in the subsurface layers the cytoplasm is often stained with Rose Bengal, Sudan black B, or eosin (Petrushevskaya 1971b; Swanberg and Biørklund 1986; Abelmann and Gowing 1997). Although this technique can furnish some clues on the living depth ranges of the species, it does not provide unequivocal information because of uncertainties associated with the speed of decomposition of the protists' cytoplasm. Boltovskoy and Lena (1970), for example, concluded that specimens of several planktonic foraminifera still contained protoplasm in their shell 98 days after death. Bernhard (1988) compared estimates of the proportions of presumably live benthic Foraminifera as indicated by Rose Bengal and Sudan black B staining and by ATP assay, concluding that stained protoplasm was present in individuals up to four weeks after actual death of the cell. These lapses are significantly longer than the time it takes a radiolarian shell to reach the sea-floor (Takahashi and Honjo 1983).

Unless special cytological studies are required (e.g., Petrushevskaya 1986), plankton and sediment trap samples can be preserved in $4-5 \%$ formaldehyde; the addition of picric acid to the solution enhances the preservation of the colonies, yet acidification should be avoided if the calcareous plankton is to be saved from dissolution.

\section{Sample preparation and analysis}

The following section offers some general comments on the preparation of whole samples for routine counting and identification procedures. It does not review the methods involved in special cytological and ultrastructural studies (see Anderson 1983a, for a review of these topics), as well as those used for detailed taxonomic work, which can involve thin-sectioning, etching and polishing, etc. (Riedel and Sanfilippo 1977; Boltovskoy et al. 1983; Petrushevskaya 1986).

Pelagic surface sediments are usually clean enough as to require little treatment before preparation of the slides. Elimination of the organic matter and disaggregation of the materials is achieved by boiling the sample (5-10 g) for a few minutes in a beaker with water to which hydrogen peroxyde $(10 \%, 300 \mathrm{ml}$ per liter) and tetrasodium pyrophosphate (10 g per liter) have been added. Disaggregation, cleaning and removal of clay coatings and infilling particles can be aided by treating the sample in a gentle ultrasonic bath. For further disaggregation of heavily indurated sediments various products, such as kerosene, paint thinner, or ammonia can be helpful (the sediment is dried, soaked in the solvent, and then immersed in water, upon which disaggregation usually occurs rapidly). If calcareous material is abundant it can be removed with a few drops of hydrochloric acid (after eliminating the hydrogen peroxyde by wet-sieving). The resulting clean material is then sieved with abundant water in order to eliminate the 
reagents and smaller particles. The mesh size used depends on the aims of the study; most surveys routinely employ 40-60 $\mu$ m-meshes, yet these, as described above, miss many of the smaller species, as well as most developing forms. If precise abundance estimates are sought, mesh openings around 15 to $20 \mu \mathrm{m}$ should be employed, although these will retain large numbers of unidentifiable skeletal fragments, as well as non-radiolarian material (especially diatoms), which can make subsequent observation more laborious. The clean residue in the sieve is pipetted onto glass microscope slides, dried, and soaked with a few drops of xylene; before the xylene has evaporated the mounting medium is added and covered with a cover glass. Canada Balsam is most often used for these preparations, although it takes longer to harden than some other synthetic materials, commercially known as Norland, Pleurax, Hyrax or Depex.

Moore (1973) proposed a convenient method which allows quantification of the number of radiolarian shells per unit weight of sediment. Before processing as described above, the sample is dried and weighed. This weighed sediment is then cleaned and sieved, and all the resulting residue is poured into a large (e.g., $5 \mathrm{I}$ ) beaker full of distilled water, on the bottom of which one or two cover gasses have been positioned. The water with the sediment in the beaker is then thoroughly stirred (avoiding rotational motion, which will result in centrifugal fractionation) for achieving a random distribution of the particles, and the sediment is allowed to settle. With the aid of a siphon all but $30-50 \mathrm{~mm}$ of water are removed, and the remainder is evaporated with an overhead infrared lamp. When the surface of the cover glasses is dry they are removed from the beaker and mounted as described above. The slide thus prepared will contain a fraction of the radiolarian shells present in the original sample, this fraction being equivalent to the proportion that the surface of the cover glass makes of that of the surface of the bottom of the beaker.

Preparation of plankton and sediment trap samples is somewhat more labororious due to the large amounts of organic material they contain. When both absolute radiolarian concentrations and specific inventories are sought, it is recommended that counting be performed separately from the identifications. Polycystines can be counted (although not identified) in whole, unprocessed samples in counting chambers under the inverted microscope (Hasle 1978; Boltovskoy 1981c; Villafañe and Reid 1995). Subsequently, either the entire sample or a subsample can be treated in order to eliminate all organic matter leaving the clean siliceous skeletons that will be mounted as described above for sedimentary materials. It should be born in mind, however, that radiolarian cells are often very difficult to recognize in preserved, unprocessed plankton samples. The siliceous skeleton, usually the most conspicuous distinguishing feature, is obscured by the cytoplasm to such an extent that radiolarians are easily confused with other planktonic protists, fecal pellets, eggs, various organic aggregates, debris, etc. Adding a few drops of hydrogen peroxide and/or hydrochloric acid, which slowly digest the organic matter, and comparing the dubious particles before and after treatment can greatly help to pinpoint radiolarian cells (Alder, personal commun. 1997).

Several different methods have been used for eliminating organic material from watercolumn samples, including high- and low-temperature ashing, oxidizing with hydrogen peroxide and/or ultraviolet light, etc. (see review in Boltovskoy et al. 1983). One of the 
most widespread, however, is that proposed by Simonsen (1974) for cleaning diatom frustules. The plankton sample is rinsed with abundant fresh water (wet-sieving), and placed in a beaker to which an equal volume of saturated $\mathrm{KMnO}_{4}$ is added; it is then left for $24 \mathrm{hs}$. A volume of concentrated $\mathrm{HCl}$ equivalent to that already contained in the beaker is subsequently added to the sample; the dark brown liquid is gently heated until it becomes transparent or light yellow. Once the sample has cooled, it is sieved again thoroughly with fresh water and rinsed with distilled water. The residue is pipetted onto microscope glass slides as described above.

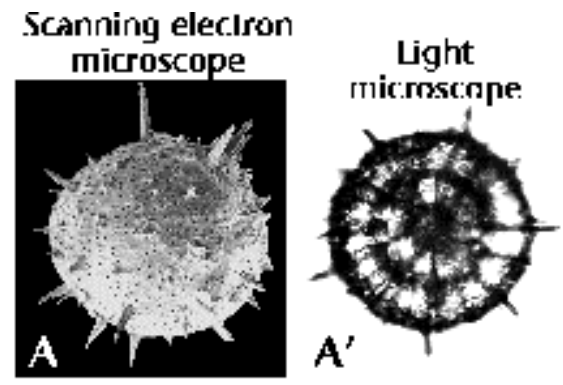

Figure SA.

Analysis of the specimens is best performed in mounted slides, which by transparency permits observing the internal structures (such as medullary shells, spiral structures, etc.), and the wall-thickness. In addition, slight variations in the depth of field allow one to determine whether a shell of circular outline is a disc (in which case most of the surface is in focus simultaneously), or a sphere (either the central part or the periphery are in focus).

Photographs taken in the light microscope have the advantage of being readily comparable to mounted specimens. The scanning electron microscope (SEM), on the other hand, is especially suitable for analyzing the surface morphology, but only in specimens with large openings in the outermost shell, or in those partially broken, can internal structures be observed. SEM photographs produce very appealing results, but their comparison with routine collections mounted in

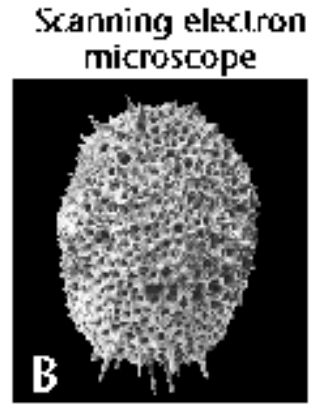

Figure SB.

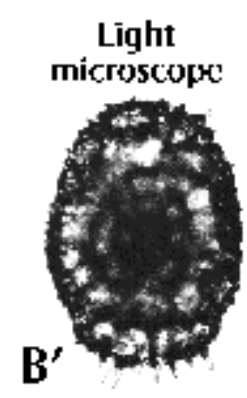

slides is tricky (see Figure 5A, 5B, $\underline{5 C}$ ).

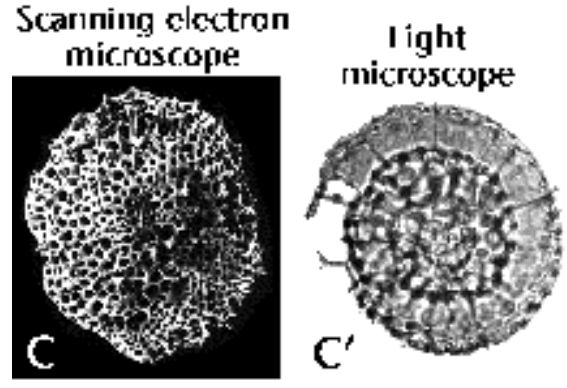

Figure 5C.

Ideally, both techniques should complement each other (Boltovskoy et al. 1983, described a method which allows performing light and SEM observations and photographs of the same radiolarian specimens).

Assessment of radiolarian species-specific absolute and relative abundances are based on identifications and counts. Since any given slide often contains thousands of polycystine shells, the researcher is forced to decide how many specimens should be identified and counted in order to achieve an adequate estimate of overall numbers and species proportions. Several methods have been proposed for the assessment of bias in sample-based particle counts (see reviews in Venrick 1978, 1995; Frontier 1981), and in the appraisal 
of species proportions (Patterson and Fishbein 1989; Buzas 1990). Patterson and Fishbein (1989) concluded that for species representing $>50 \%$ of the overall taxocoenosis at least 50 specimens should be counted in order to achieve reliable percentage data, 300 counts for species which comprise approximately $10 \%$ of a sample, $500-1000$ counts for species that make up 5\%, and counts of several thousands for those that comprise $1 \%$. Unfortunately, in the case of the polycystines these efforts are unrealistic because in any given sample containing 100-150 species only one-three are above 10\%, and $70-90$ occur at levels below $1 \%$ (see "Geographic and vertical distribution"). In terms of the amount of information attained, it is more profitable to analyze more samples at a lower resolution, than to examine fewer sites at these statistically more reliable levels. Thus, in practice proportions are estimated in bulk, regardless of the individual species abundances, usually scanning 300-600 specimens per sample. It is common practice to identify the first $300-600$ individuals on the slide, and then check the rest of the slide or slides for the given sample in order to account for the rarer taxa. The relative abundances of the latter are estimated approximately, and they are usually excluded from subsequent general numerical analyses (e.g., multivariate techniques, such as cluster and factor analysis) because of the uncertainties associated with their assumed absences. It should be stressed, however, that the counting effort necessary for reliable estimates of the fractional abundance of the rare species is inversely proportional to the equitability of the assemblage. Thus, when the sample is strongly dominated by a single or only a few taxa, such as in polar areas, chances of recording the rare polycystines in random sequential counts are low because the observer repeatedly hits the dominant species. On the contrary, as equitability increases so does the probability of logging a so far unrecorded species with every new specimen scanned.

\section{GEOGRAPHIC AND VERTICAL DISTRIBUTION}

\section{Sedimentary vs. water-column materials}

As opposed to other zooplanktonic groups, studies on the geographic distribution of extant polycystines have been chiefly based on sedimentary - rather than on planktonic - materials. As mentioned above, sediment samples present some advantages, but also several important shortcomings.

Whereas polycystine abundances seldom exceed five cells per liter in the plankton (e.g., Caron and Swanberg 1990), one gram of (dry) surface sediments can contain thousands to hundreds of thousands of radiolarian skeletons. Plankton samples yield a snapshot-type image of the composition of the assemblages, which does not necessarily adequately reflect long-term trends. The daily, seasonal and interannual variability involved is smoothed out in the sedimentary record, which may be a welcome trait when general patterns are sought. Further, sedimentary materials are more readily available from the various repositories around the globe than plankton samples. In any case, plankton samples not collected for microplanktonic purposes may be useless for 
radiolarian studies due to inadequate net mesh-size.

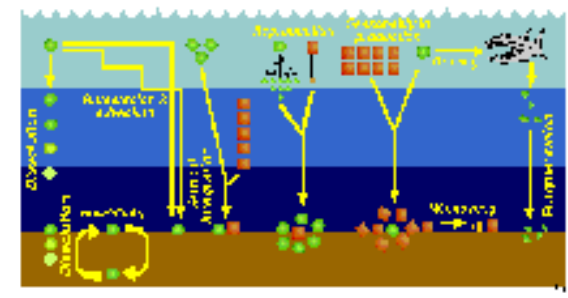

Figure 6.
On the other hand, interpretation of the geographic distribution of extant radiolarian assemblages on the basis of sediment samples presents several important drawbacks (Boltovskoy 1988, 1994, 1995; Kling and Boltovskoy 1995; Figure 6). On their way to the sea-floor and after settling, radiolarian remains are grazed upon by various consumers thus breaking their skeletons into unidentifiable fragments. Because more delicate shells are destroyed more readily than the more robust ones, specific makeups on the bottom and at mid- depths can differ significantly from the living assemblage in the upper watercolumn (Boltovskoy et al. 1993b, 1995). Selective dissolution of whole siliceous skeletons en route to the sea-floor and after deposition, although often advocated as an important source of plankton vs. sediments dissimilarities (e.g., Petrushevskaya 1971b; Renz 1976), is probably much less critical than fragmentation due to grazing (Boltovskoy and Alder 1992; Morley et al. Ms). Bottom materials can be reworked after deposition (as a result of which non-Recent deposits, sometimes characteristic of quite dissimilar oceanographic settings, are brought up to the surface layer, or winnowed by bottom currents (dislodging settled skeletons and carrying them thousands of kilometers away; Figure 6). Sediments integrate the imprint of near-surface faunas (which are generally associated with surficial temperature, salinity and primary production fields, as well as with currents and water masses), with the meso- and bathypelagic species whose geographic distribution is uncoupled with upper-water oceanography (Figure 6). In general terms the sedimentary distributions of cold-water species tend to show conspicuous equatorward extensions as compared with their planktonic patterns. This distortion is most probably due to the fact that extended survival of the expatriated cold water taxa is facilitated by submersion (Boltovskoy 1988, 1994; Figure 6); as a consequence, sediment-derived species-specific ranges may wrongly suggest an enhanced tolerance to gradients in the ecological factors.

While these limitations stress the need for caution in biogeographic interpretations based on sedimentary materials, the usefulness of bottom samples for biogeographic, paleobiogeographic and paleoecologic purposes has been confirmed in many reports and is certainly beyond doubt. Furthermore, when compared with water-column materials, sedimentary ones can furnish much useful distributional and ecological data (e.g., Boltovskoy et al. 1993b; 1995), usually unavailable from plankton or sediment trap samples alone.

\section{Geographic patterns}

Polycystines are typically open-ocean organisms, occurring throughout the World Ocean. However, distinct coastal associations, while uncommon or absent altogether in areas with an extended shelf, such as the Southwestern Atlantic (Boltovskoy 1980), 
have been described in various studies. For example, Norwegian fjords host dense and diverse radiolarian assemblages, which differ from those of the open Norwegian Sea (Swanberg and Bjørklund 1986, 1987, 1992). Interestingly, two of these fjord species, Rhizoplegma boreale (probably synonymous with Spongosphaera streptacantha), and Phormacantha hystrix/Plectacantha oikiskos, have been found to strongly dominate (up to $47 \%$ of all polycystines) shallow, coastal sediments around Antarctica (Nishimura et al. 1997). General differences between presumably neritic vs. oceanic radiolarian assemblages have been described occasionally in the literature (Kruglikova 1984), and even used for paleoenvironmental reconstructions (e.g., Palmer 1986). However, with the probable exception of specific diversities, which indeed seem lower in neritic assemblages (Nishimura et al. 1997), and the fact that a few selected polycystines are probably less intolerant to near-shore conditions than the bulk, most other traits (such as Spumellaria:Nassellaria proportions, percentages of Spongodiscidae, percentages of "spiny Porodiscidae", percentages of small "Cyrtoidea"; cf. Kruglikova 1984) need further confirmation.

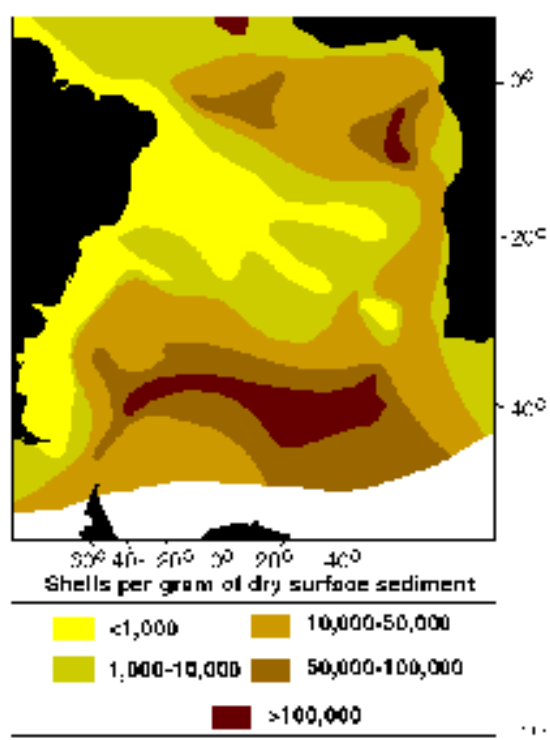

Figure 7.
Polycystine densities are typically around $0.3-1$ cells per liter, but values exceeding 50 ind. $I^{-1}$ have been recorded in some productive areas (Caron and Swanberg 1990). The quantitative distribution of polycystines in surface sediments of the South Atlantic is illustrated in Figure 7. This pattern is probably an approximate representation of their concentrations in the water-column as well, and it also roughly reflects the overall distribution of primary production (e.g., Koblentz-Mishke and Vedernikov 1977), and of phytoplanktonic (Semina 1977) and zooplanktonic (Bogorov et al. 1968) biomasses. Highest numbers of polycystines would thus be expected along the upwelling areas off Africa (Abelmann and Gowing 1997), where the highest radiolarian fluxes have been recorded to day (Boltovskoy et al. 1996), and in the equatorial current system. In the southern part of the ocean high densities are probably associated with the

subantarctic belt and its northern extensions, the Malvinas (=Falkland) and the Benguela Currents. In a transect between the Antarctic and approximately $30^{\circ} \mathrm{S}, 10^{\circ} \mathrm{E}$ (off Namibia), Abelmann and Gowing (1997) recorded highest polycystine densities at $100-300 \mathrm{~m}$ in Antarctic waters, and at 0-150 $\mathrm{m}$ in subantarctic waters (up to 0.3 ind. ${ }^{-1}$; these values, however, may be somewhat underestimating, see Boltovskoy and Alder 1992). In the Southwestern Atlantic (30-60 , along $\left.55^{\circ} \mathrm{W}\right)$, surface $(5-15 \mathrm{~m})$ layers were found to host 0.5 polycystines per liter on the average, with maximum concentrations of three shells per liter (Alder et al. 1997). Lowest numbers are those present in Central Gyre and Tropical/Subtropical waters (see Figure 7).

Flux rates of radiolarian shells at depths between 50 and ca. $5000 \mathrm{~m}$ vary from $0-4$ to 
over 100,000 ind. $/ \mathrm{m}^{2} /$ day (Boltovskoy et al. 1993a), with highest numbers having so far been recorded in the north-eastern tropical Atlantic $\left(201,064 \mathrm{shell} / \mathrm{m}^{2} / \mathrm{day}\right.$; cf.

Boltovskoy et al. 1996).

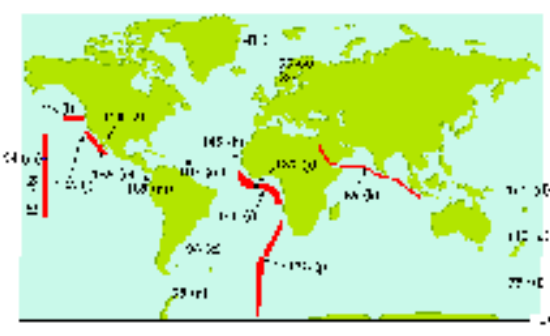

Figure 8.

The numbers of species that inhabit the different climatic zones of the World Ocean are difficult to estimate because most authors restrict their scopes to some 2040 more or less well-defined morphotypes, ignoring the rest of the species. The few surveys that (presumably) did attempt to identify all the skeletons recorded indicate that these numbers oscillate around $100-200$ for the tropics and subtropics, dropping to some 50-60 at the

poles (Figure 8).

This decrease, however, is often punctuated by an isolated peak in the transitional areas which usually host both cold water and warm water taxa, especially in the sediments (see Figure 9) (Boltovskoy 1981d, 1982, 1986).

Despite these rather high numbers, very few of the species are abundant in any given sample. In terms of their relative contribution to the overall polycystine assemblage, usually only one-three species exceed
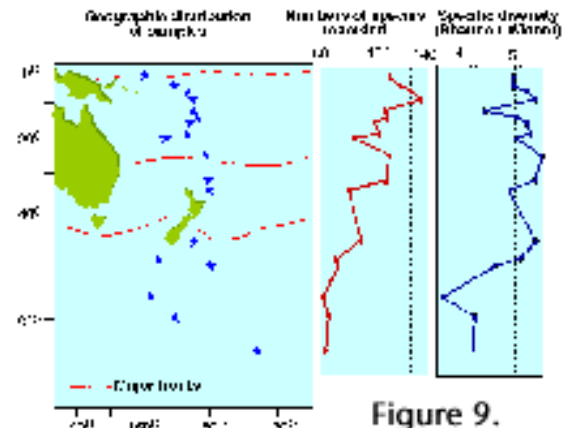

Figure 9 . $10 \%$, and up to five represent over $5 \%$; radiolarians whose average percentage abundances are below $1 \%$ of the fauna usually comprise $70-90 \%$ of all the species recorded (Figure 10).

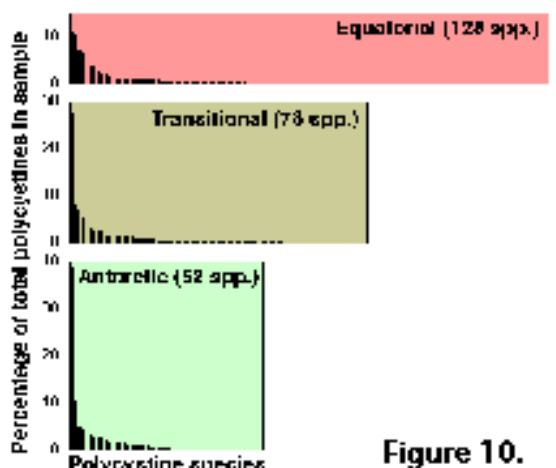

Of the 164 polycystines included in this review, around 10 can attain average proportions in excess of $10 \%$ in any given area, $12-15$ morphotypes can reach $5-7 \%$, and ca. $50-70$ are normally around $1-3 \%$ (Table 1). The remaining half of the polycystine species are present at levels below $1 \%$. Highest dominances are associated with polar environments, where a single species or species group can account for $25-40 \%$ of the assemblage (e.g., Antarctissa spp. in the Antarctic, cf.

Figure 10. Boltovskoy 1987; Amphimelissa setosa in the Greenland Sea, cf. Swanberg and Eide 1992; Phormacantha hystrix/Plectacantha oikiskos and Rhizoplegma boreale, probably synoymous with Spongosphaera streptacantha, in coastal Antarctic sediments, cf. Nishimura et al. 1997; see Figure 10).

Species-specific distributional data for the South Atlantic are scarce and fragmentary. 
Boltovskoy (1981e) produced a detailed listing of all known Southwestern Atlantic records up to that date, which basically represented 7 reports (Haeckel 1887; Hays 1965; Nigrini 1967; Goll and Bjørklund 1974; Lozano and Hays 1976; Morley 1977; and Boltovskoy and Riedel 1980), chiefly based on sedimentary materials. This objective compilation produced a spotty picture with no discernible patterns. In the 15 years elapsed since that review several contributions based on South Atlantic materials appeared, but they mostly focused on downcore analyses (e.g., Pisias and Moore 1978; Coco 1982; Weaver 1983; Bjørklund and Jansen 1984; Grinstead 1984; Charles and Morley 1988; Alperín 1987), or were restricted geographically to rather small areas (Robson 1983; Dworetzky and Morley 1987; Boltovskoy et al. 1993a, 1993b, 1995, 1996; Abelmann and Gowing 1997).

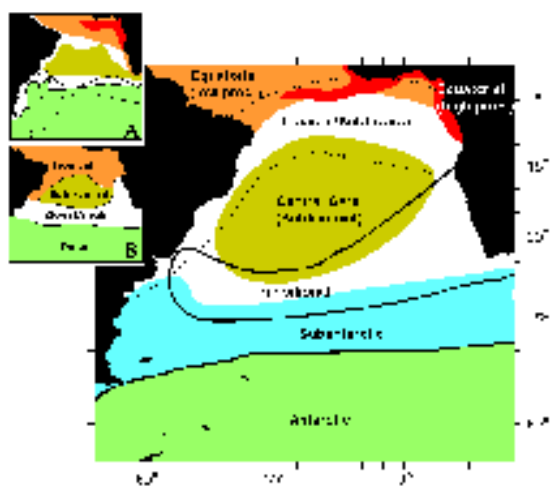

Figure 11.

Thus, in order to furnish a more comprehensive insight into polycystine biogeography in the South Atlantic, distributional species-specific data are referred to the 7 distinct areas illustrated in Figure 11). These divisions take into account the distribution of general planktonic biogeographic provinces (e.g., E. Boltovskoy 1970; Koblentz-Mishke and Vedernikov 1977; Boltovskoy 1979, 1981d, 1982, 1986; Dadon and Boltovskoy 1982; Longhurst 1995), as well as radiolarian-based biogeographic patterns (Goll and Bjørklund 1974; Morley 1977; see Figure 11, insets A and B). For some of the especially abundant and better defined taxa relative (percentage) contributions to all polycystines can be predicted with reasonable accuracy. For most others, however, only a very rough indication of their numbers (abundant, present) can be offered for the time being.

The information used to compile Table 1 was not restricted to data from the South Atlantic Ocean, but was extracted from many reports on various oceanic areas, putting special emphasis on water column-based surveys (see "Sedimentary vs. water-column materials" above). Although very subtle differences between oceanic basins probably do exist (Nigrini 1967; Goll and Bjørklund 1974), polycystine species are chiefly restricted in their distribution by climatic and productivity fields, rather than by ocean basins, as are most other pelagic planktonic organisms. Thus, with very few exceptions, similar assemblages characterize the equatorial circumglobal belt, the subtropical zones of the two hemispheres, and the polar waters (Petrushevskaya 1971a). Geographic endemics are rare, probably accounting for less than $5 \%$ of all the species (one outstanding example is Antarctissa spp., Figure 15.104, which is absent in the Arctic, but dominates both the plankton and the sediments of the Antarctic zone).

It should be born in mind that the degree of mixture between most of the areas shown in Figure 11 is extremely large. For example, in the western South Atlantic the Transition Zone stretches up to almost 15 degrees in latitude (ca. $34-35^{\circ} \mathrm{S}$ to $47-48^{\circ} \mathrm{S}$; Subantarctic species are regularly found here in the same tows as the Subtropical representatives (E. Boltovskoy 1970, 1981a, 1981b; E. Boltovskoy et al. 1996). 
Because the Brazil current is a southwest flowing branch of the South Equatorial Current, tropical assemblages differ little from the subtropical ones. Central Gyre fauna is also very similar to the Tropical and Subtropical one, yet these oligotrophic waters, characterized by very low overall plankton abundances, host enhanced proportions of several colonial radiolarians.

\section{Vertical profiles}

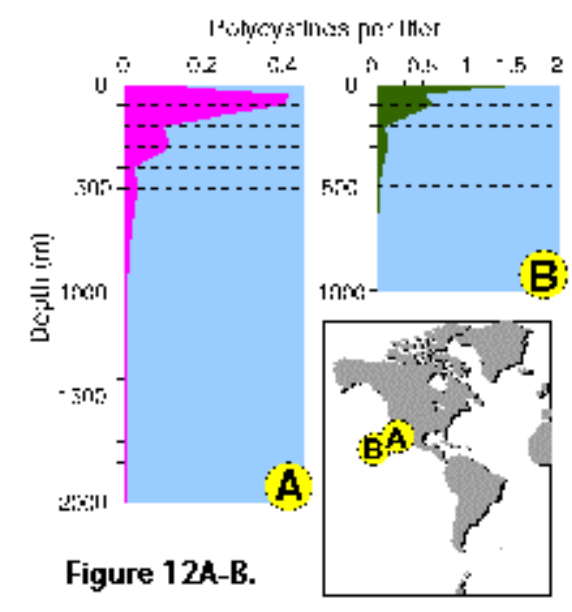

associated with the Warm Deep Water and occur deeper, at 200-400 m (Petrushevskaya 1967; Boltovskoy and Alder 1992; Abelmann and Gowing 1997; Figure 12D, 12E).

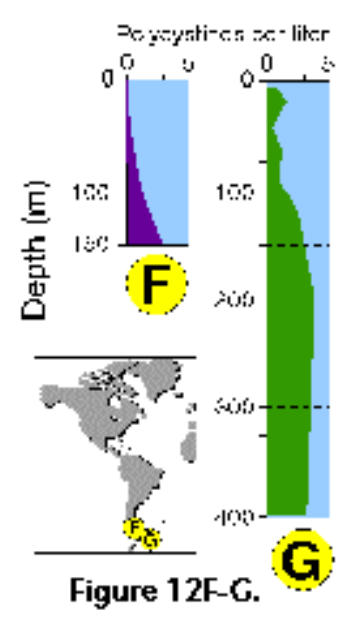

Many radiolarian species occupy discrete depth intervals of the water column. Kling and Boltovskoy (1995), on the basis of a series of plankton tows in the upper $2000 \mathrm{~m}$ in the eastern subtropical Pacific defined the following characteristic layers: (1) surface (with maxima at $0 \mathrm{~m}, 25$ $\mathrm{m}, 0$ and $50 \mathrm{~m}, 50 \mathrm{~m}$, or 0 and $100 \mathrm{~m}$ ), (2) subsurface (maximum at $100 \mathrm{~m}$ ), (3) deep (maxima at $200 \mathrm{~m}, 200$ and $300 \mathrm{~m}$, or $300 \mathrm{~m}$ ), and (4) species peaking below $300 \mathrm{~m}$. Roughly similar zonations were established by other authors as well (e.g., Renz 1976; Dworetzky and Morley 1987; Kling 1979). Worldwide depth zonations, however, cannot be defined in terms of fixed depths because the distribution of radiolarian species is related to water masses which move vertically as well as horizontally. For example, in the eastern subtropical Pacific inshore and oceanic 0-25 m waters can host a typically 
warm-water assemblage associated with the Central Water which is advected coastward by the Southern California Eddy, while midway between these two sites the same depths are inhabited by a conspicuously different, colder-water assemblage associated with the cooler waters of the California Current (Kling and Boltovskoy 1995). Many cold water radiolarians that inhabit the upper layers at high latitudes submerge with their corresponding water masses and can be found at depth in mid- and lowlatitude areas (Kling 1976; Boltovskoy 1988; Steineck and Casey 1990). Siphocampe arachnea (Figure 15.167), for example, is a dominant component of surface Pacific Arctic and Subarctic plankton; in the central north Pacific it peaks at 100-300 m, and at 300-1000 m in the subtropical eastern Pacific (Boltovskoy 1994).

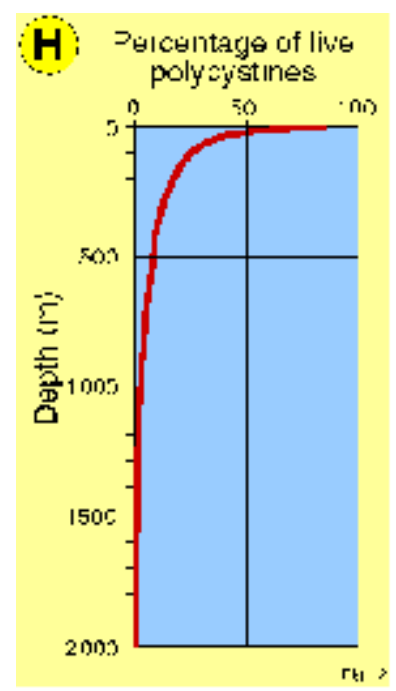

Figure $12 \mathrm{H}$.
Changes in the proportions of presumably living polycystine cells with depth have been assessed in a few studies. Boltovskoy et al. (1993a), based on extensive sediment trap data, concluded that numbers of live specimens decrease drastically downwards (e.g., aprox. $100 \%$ at $0 \mathrm{~m}, 50-60 \%$ at $100 \mathrm{~m}, 20-40 \%$ at $200 \mathrm{~m}, 10-20 \%$ at $500 \mathrm{~m}, 5 \%$ at $1000 \mathrm{~m}$; see Figure $12 \mathrm{H}$ ). These results generally agreee with other studies (e.g., Petrushevskaya 1971a; Kling and Boltovskoy 1995). On the other hand, Abelmann and Gowing (1997) estimated much higher proportions of living cells at comparable levels in the water column: over $90 \%$ at $100-200 \mathrm{~m}$, around $70 \%$ at $300-500 \mathrm{~m}$. It should be noticed that staining techniques, which are usually applied for these estimates, do not adequately differentiate between live and dead cells (see above "Provenance and collection of materials"), for which reason it is probable that concentrations of living specimens below 50-100 m are systematically overestimated in such surveys (Boltovskoy et al.

1993a; see Figure 12H).

As with geographic patterns, data on the depths at which the various species peak listed in Table 1 have been compiled from reports on different oceanic areas. It is anticipated that they are generally valid for subtropical and tropical environments worldwide; at higher latitudes, however, some deep species may occur closer to the surface, while in the Antarctic the bulk of the asssemblages seems to occupy deeper layers (see above).

\section{TAXONOMY}

\section{Morphology and classification systems}


Based on his previous monograph of 1862 , and especially on the extensive collections of $H M S$ Challenger, Haeckel (1887) produced the first comprehensive system of radiolarian classification, encompassing over 3,000 species, 2,400 of which were new to science. Although Haeckel's work is still a compulsory reference guide for anyone attempting to deal with the identification of these organisms, it has for some time been evident that it does not satisfactorily represent natural relationships. Indeed Haeckel's groupings are only based on morphological similarities without the support of continuity in the fossil record, rather than on demonstrable evolutionary sequences. In

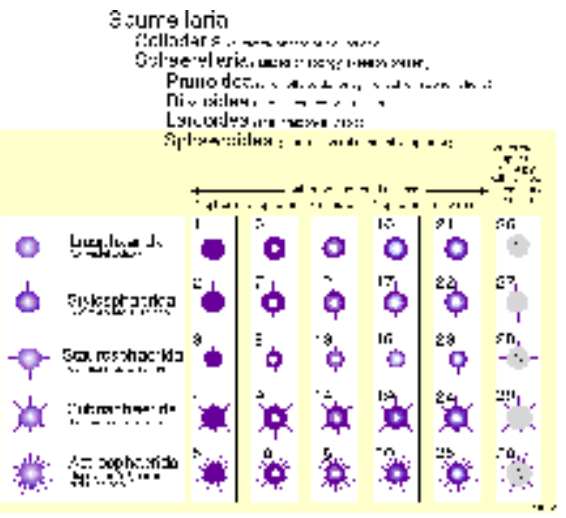

Figure 13. addition, the rigidity of his diagnoses, based chiefly on strict geometric considerations (Figure 13), ignores the ample intraspecific variability of the polycystines. As a result, many of his described "species" are but slightly different morphotypes or even developmental stages of the same organism (see Figure 13 and Figure 14).

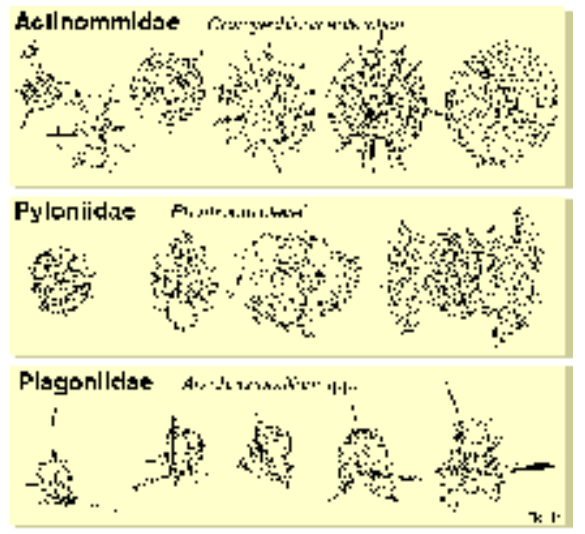

Figure 14.

In spite of these shortcomings and the time elapsed, advances in the development of a better classification system have been very limited. Efforts to depart from and improve upon the classification schemes inherited from earlier workers have mainly followed two different approaches: cytological techniques and evolutionary studies.

Hollande and Enjumet (1960), Cachon and Cachon (1972), Petrushevskaya et al. (1976), Petrushevskaya (1981) proposed revisions which use not only the skeleton (as most other classifications), but also cytoplasmic features, in particular the "nucleoaxopodial complex" (sensu Petrushevskaya 1981). Although these schemes are probably sounder in biological terms, their applicability to fossil and subfossil materials lacking the protoplasm is problematic, which is one of the reasons for their very limited acceptance among radiolarian workers.

Analyses of evolutionary lineages in geological sequences were somewhat more succesful than cytological techniques in defining characters applicable to classification. Based on evolutionary evidence, Riedel and Sanfilippo (1986) produced an interesting critical review of the most important skeletal traits used by Haeckel. They concluded that some of them (e.g., number of segments, number of supplementary concentric spheres, number of feet, number of rays and of equatorial spines in discoidal Spumellaria, presence and nature of thoracic wings) have little or no suprageneric value. In contrast, several others (especially cephalic structure, but also pore 
arrangement, shell terminations in Nassellaria, etc.), traditionally considered as of minor value, are conservative through time, reveal evolutionary lineages and, therefore, are relevant for higher-rank divisions.

Riedel (1967b, 1971), Petrushevskaya (1965, 1971a), Goll (1968, 1969), Sanfilippo and Riedel (1970), Zhamoida and Kozlova (1971), Foreman (1973), Dumitrica (1988, 1989) based on skeletal features alone worked out alternative classifications, either for the entire order or for selected polycystine groups. Of these, Riedel's (1967b, 1971) suprageneric system has become the most widely accepted for extant and Cenozoic radiolarians, and is the one adopted herewith (with slight modifications; see also Kling 1978; Boltovskoy 1981e; Anderson et al. 1996). It should be stressed, however, that this system does not overcome many of the above-mentioned problems, and is therefore a compromise provisional classification. Several of the family-level definitions, especially in the Spumellaria, are rather vague and generally used as a lumping black box for the many forms with complex morphologies and poorly understood relationships (e.g., Litheliidae, Pyloniidae, Tholoniidae).

Specific identification of the polycystines is a time-consuming and frustrating task. With the exception of the few abundant and widespread species on whose names there is fairly good agreement, binomial nomenclature alone very often fails to pinpoint unequivocally a given morphotype because different names are applied to the same species and, conversely, identical organisms are reported under different specific and even generic names (see Boltovskoy and Jankilevich 1985). Because a very substantial proportion of the original species descriptions were published in old and often hard to get monographs, some authors find it faster and easier to create a "new species" for the unusual-looking skeleton in the slide, than to comb the dusty books in search of an adequate, already established name. Ecologically, paleoecologically and stratigraphically-oriented studies often underestimate the importance of a stable and consistent naming system; the lack of species illustrations in these reports allows the wrong designations to go undetected. This not only hinders buildup of useful information, but also significantly degrades the overall quality of radiolarian-based data for other applications. Recent literature has abundant examples of this bias, which introduces even more chaos into the already anarchic situation inherited from turn of the century works. Indeed, this may be a major reason for the waning use of radiolarians in stratigraphic and paleoecologic work.

The following illustrated glossary of most commonly used terms for the description of polycystine skeletons is chiefly based on the listing compiled by Petrushevskaya (1981). Capital letters (in parentheses) denote the group for which the term is used (N: Nassellaria; S: Spumellaria). 
Abdomen $(\mathrm{N})$ (Figure 30, 3P): the third segment of nassellarian multisegmented shells.

- Aboral, aboral pole (N): skeletal section located at the opposite extreme of the mouth or aperture. Nassellarian growth starts with this part of the skeleton.

- Adoral teeth: see teeth.

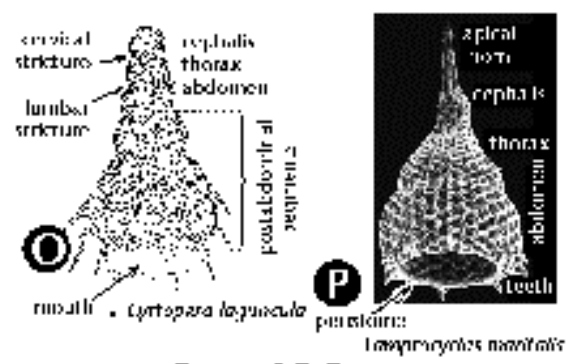

Figure 30-P.

- Annular strictures: see strictures.

- Antecephalic chamber: see antecephalic lobe.

- Antecephalic lobe (N) (Figure 3M, 3N):

Section of the cephalis at the base of which the dorsal spine is located. Separated from the eucephalic lobe by the apical spine. When this section is separated from the rest of the shell by a pored wall it is called the antecephalic chamber.

- Aperture: see mouth.

- Apical cupola: see galea.

- Apical horn (N) (Figure 3P): external extension of the apical spine.

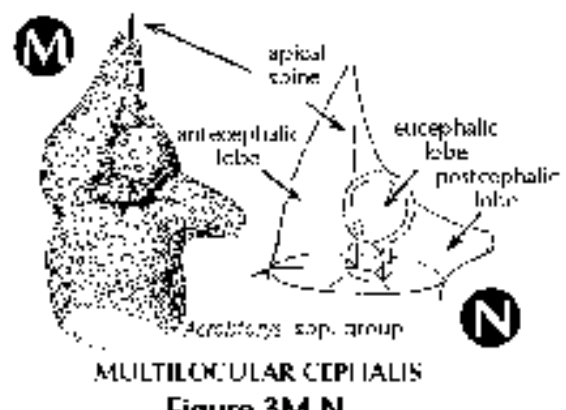

Figure 3M-N.

- Apical pore $(\mathrm{N})$ : wall-pore located at the base of the apical spine.

- Apical spine (N) (Figure 3A, 3B):

Internal cephalic spine which branches off the median bar close to the point of insertion of the dorsal spine. The apical spine can protrude outside of the cephalis, in which case its external section is called apical horn.

- Apical tube (N) (Figure 3J): Tube-like projection on the cephalis of the Artrostrobiidae, homologous to the vertical spine. Also termed lateral tube or tubule.

- Apophyses (N, S): any external or internal

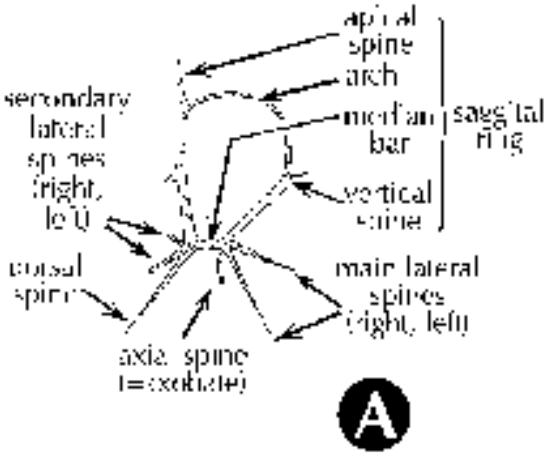

Figure 3A. protruding outgrowth of the skeletal meshwork.

- Appendages $(\mathrm{N})$ : any external or internal protruding outgrowth of the skeletal 
meshwork. Riedel and Sanfilippo (1986) suggested that primary appendages (those directly connected to or having homologies with the internal spicule) are of higher phylogenetic significance than the secondary ones (not directly related to the internal spicule).

- Arches (N): anastomosed skeletal outgrowths of the main spines, such as the one forming the upper section of the sagittal ring (Figure 3A).

- Areolate (N, S): Referring to small, very regularly repeated wall perforations or pores.

- Arms (S) (Figure 2Q, 2R): elongate projections (usually 3 ) radiating from a central subcircular

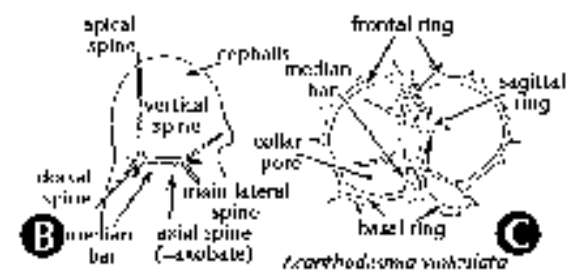

Figure 3BC. disc in the shells of some Spongodiscidae. Arms can consist of unstructured spongy meshwork (Figure 2Q), or of spongy meshwork with more or less clearly visible chambered rings (Figure $2 \mathrm{R}$ ).

- Axial rod: see axial spine.

- $\quad$ Axial spine $(\mathrm{N})$ (Figure 3A, 3B): spine projecting from the median bar and oriented toward the thorax and subsequent segments; can be simple or branched. Also called axobate.

- Axobate: see axial spine.

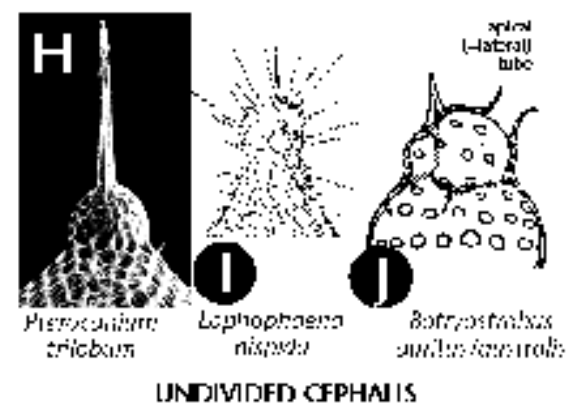

Figure 3HIJ.

- Axoneme (N, S): the central shaft of parallel microtubules of the axopodia (cytoplasmic structure).

- Axoplast (N, S) (Figure 1A): central nucleus of the axopodial system (cytoplasmic structure).

- $\operatorname{Bars}(\mathrm{N}, \mathrm{S})$ (Figure 2F): siliceous anastomosed beams that define the meshwork of polycystine shells, separated by pores. 
- Basal feet: see feet.

- Basal plate: see collar plate.

- Basal pores $(\mathrm{N})$ : see collar pores.

- Basal ring (N) (Figure 3C): the subcircular structure formed by the arches that separate the wall of the cephalis from that of the thorax. In reduced skeletons, such as those of the Spyrida,

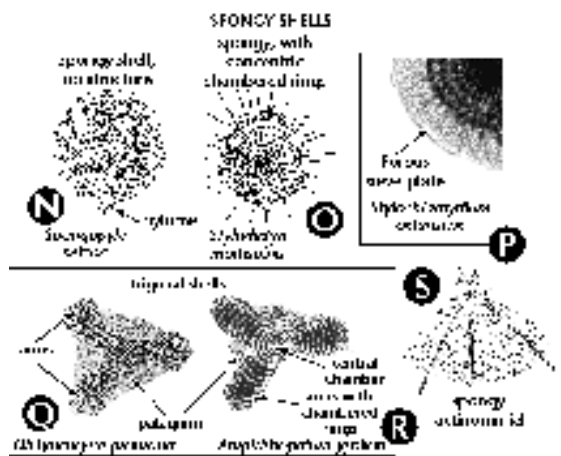

Figure $2 \mathrm{~N}-\mathrm{S}$. these arches make an actual ring, whereas in other families the ring is embedded into the shell-wall.

- Basal segment $(\mathrm{N})$ : the last segment in multisegmented Nassellaria.

- Beams (S): siliceous rods joining contiguous shell structures. In some families (e.g., Actinommidae, Pyloniidae, Litheliidae) radial beams connect the successive, concentric spheres (Figure 2A) or consecutive whorls of the spiral (Figure 2L).

- Branched spines: see spines.

- By-spines: see spines.

- Calymma (N, S) (Figure 1A): extracapsular cytoplasm (see central capsule).

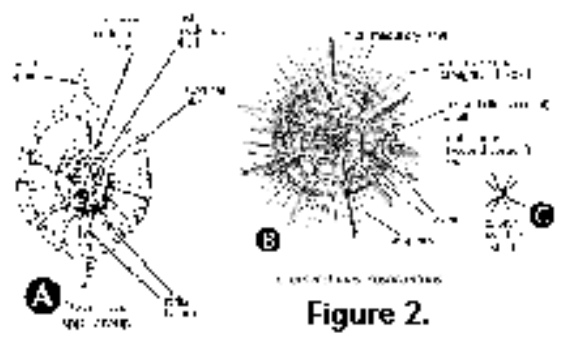

- Central capsule (N, S) (Figure 1A, 1B): an organic, perforated membrane within the radiolarian protoplasm which separates the intracapsular cytoplasm from the extracapsular one.

- Central chamber (S) (Figure 2R): the central, spherical structure of the skeleton of several Spongodiscidae.

- Cephalis (N): the first (uppermost) segment of the skeleton, which can be either undivided (Figure 3H, 3I, 3J), or divided into lobes or chambers (Figure $3 \mathrm{~K}, 3 \mathrm{M}$, $3 \mathrm{~N}$ ). The cephalis can be well differentiated from the thorax (Figure 3F, 3H, 3I, $3 \mathrm{~J}, 3 \mathrm{~K}, 3 \mathrm{~L}, 3 \mathrm{M}, 3 \mathrm{~N}, \underline{3 \mathrm{R}}$ ), or it can be immersed into it partially (Figure 3D) or totally (Figure $3 \mathrm{E}$ ).

- Cervical apophyses $(\mathrm{N})$ : lateral outgrowths of the dorsal spine. 
- Cervical pores $(\mathrm{N})$ : paired pores in the base of the cephalis between the primary lateral and the dorsal spines.

- Cervical stricture (N) (Figure 30): furrow or constriction which divides the cephalis from the thorax.

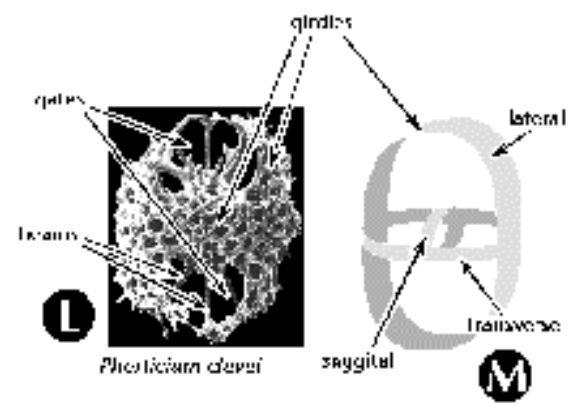

- Chamber $(\mathrm{N})$ : one of the several sections into

Figure 2L-M. which the cephalis of the Nassellaria can be divided (see antecephalic, lateral, eucephalic and postcefalic chambers). See also central chamber.

- Chambered rings (S) (Figure 2O, 2R): Concentric or spiral more or less visibly segmented rings around the central chamber in several Spongodiscidae (see arms).

- Club-like spines: see spines.

- Collar plate $(\mathrm{N})$ : the complex structure at the base of the cephalis formed by the spines and arches, all lying on approximately the same plane.

- Collar pores (N) (Figure 3C): pores in the collar plate.

- Collar stricture: see cervical stricture.

- Columella $(\mathrm{N})$ : free portion of the apical spine (Figure $3 \mathrm{~A}$ ) in the cephalis of the Nassellaria.

- Cortical shell (S) (Figure 2A, 2B): one of the

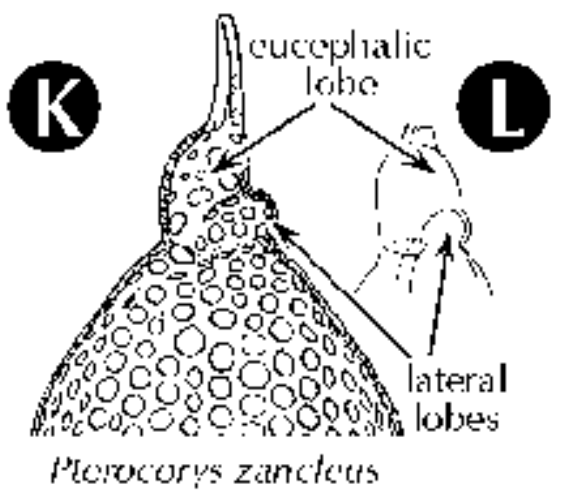

TRILOCULAR CEPHALIS

Figure 3KL. outermost perforated spherical shells of the Spumellaria, located outside of the central capsule.

- Cupolae (S) (Figure 2C): dome-like protuberances of the skeleton of the Tholonidae.

- Cylindrical spines: see spines. 
- Dorsal spine (N) (Figure 3A, 3B): Internal cephalic spine projecting from the median bar at the opposite end of the vertical spine, next to the apical and secondary lateral spines. The dorsal spine can protrude outside of the cephalis at the

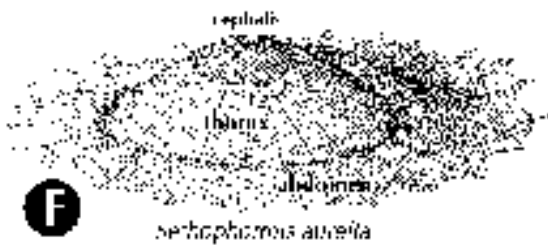

Figure 3F. level of the cervical stricture.

- Equatorial plane (S): mainly applicable to lenticular, discoidal and biconvex spumellarian shells (Figure $\underline{2 \mathrm{H}}, 2 \mathrm{I}$ ); plane of maximum shell surface.

- Eucephalic lobe $(\mathrm{N})$ (Figure $3 \mathrm{~N}$ ): in species with a divided cephalis, the section which hosts the median bar.

- Extracapsular cytoplasm: see calymma.

- Feet (N) (Figure 3Q): External projections of the wall of the thorax oriented down and sideways, usually in the number of 3 . The feet are often associated with the dorsal and primary lateral spines.

- First shell (S) (Figure 2A, 2B): the innermost shell of the set of concentric spheres of an actinommid. Sometimes also applied to members of other families with several successively larger shells totally or partially enclosing one another. Shells are numbered from the inside of the skeleton

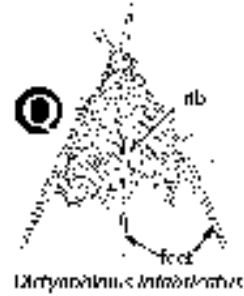

B

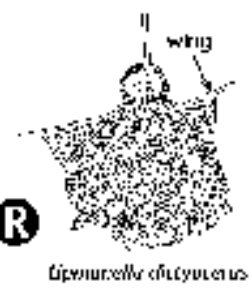

Figure $3 Q-R$. toward the periphery; thus, the second shell is the one located next to- and outside of the first one, and so on.

- Fourth shell: see first shell.

- Frames (N, S) (Figure 2D): ridges on the surface of the shell surrounding the pores. Frames around pores can be roundish or polygonal

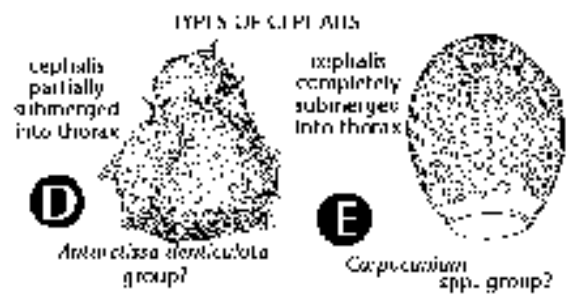

Figure 3DE. (pentagonal, hexagonal, etc.).

- Fundamental spicule: see main spicule.

- Funnel-shaped pores (N, S): pores the external opening of which is conspicuously wider than the internal one. 
- Galea $(\mathrm{N})$ : helmet-shaped portion of the shell of the Nassellaria associated with the apical horn; its base is formed by the top of the cephalis. Also called apical cupola.

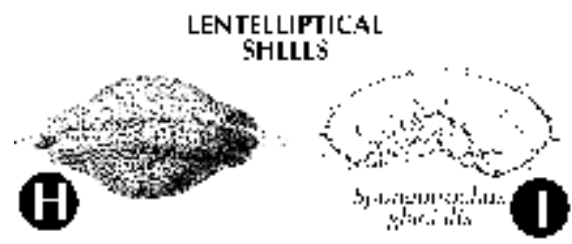

Figure 2H-I.

- Gates (S) (Figure 2L, M): large openings in the skeleton's meshwork, usually conspicuously larger than the pores (Pyloniidae).

- Girdles (S) (Figure 2L, 2M): circular or ellipsoidal skeletal perforated plates arranged in three mutually perpendicular planes which form the skeleton of the Pyloniidae.

- Internal spicule: see main spicule.

- Intracapsular cytoplasm: see central capsule.

- Jugal pores $(\mathrm{N})$ : paired pores in the base of the cephalis between the primary lateral and the vertical spines.

- Lateral lobes $(\mathrm{N})$ (Figure $3 \mathrm{~K}, 3 \mathrm{~L}$ ): lateral sections of the cephalis separated from the eucephalic portion by cephalic arches.
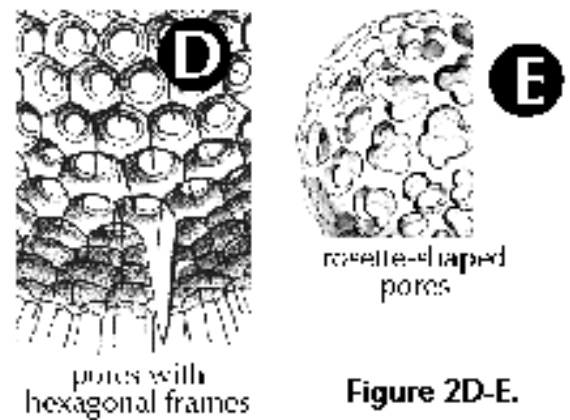

Figure 2D-E.

- Lateral spines (N) (Figure 3A, 3B): Paired spines projecting from the median bar. The main or primary lateral spines (right and left) are located in the vicinity of the vertical spine, while the secondary ones (right and left) are inserted close to the apical spine.

- Lateral tube: see apical tube.

- Latticed meshwork (N, S) (Figure 2D, 2E, 2J, 2L): siliceous meshwork of bars separated by regular or irregular pores of variable size, not spongy in appearance (see spongy meshwork). 
- Lentelliptical shell (S) (Figure 2H, 2I): in the shape of a biconvex disc.

- Lumbar stricture (N) (Figure 30): constriction between the thorax and the abdomen.

- Main lateral spines: see lateral spines.

- Main spicule: see main spines.

- Main spines (N) (Figure 3A, 3B, 3C): basic skeletal elements of most Nassellaria, composed of the median bar from which the apical, vertical dorsal and lateral spines arise.

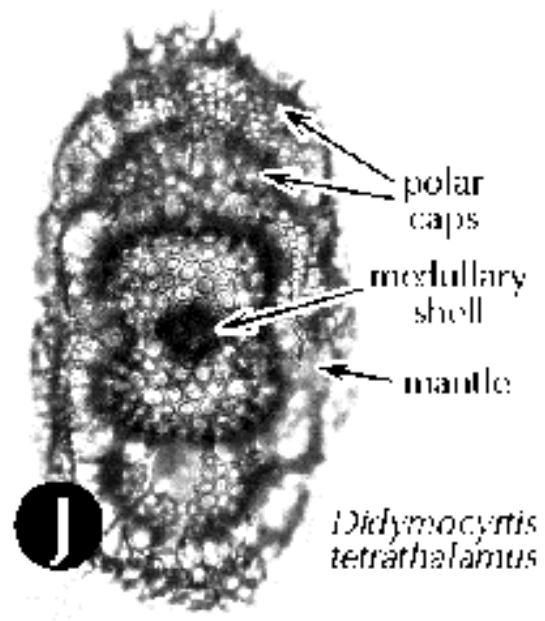

Figure 2].

- Mantle (N, S): usually thin, delicate, lace-like meshwork surrounding the main shell which appears in some fully grown polycystines.

- Median bar (N) (Figure 3A, 3B, 3C): the basic nassellarian internal skeletal element which supports the apical, vertical, dorsal and lateral spines. Its position defines the limit between cephalis and thorax.

- Medullary shell (S) (Figure 2A, 2B, 2J): one of the innermost perforated spherical shells of the Spumellaria, located inside the central capsule. The central smallest sphere $(<30 \mu \mathrm{m})$ is also called microsphere by some authors.

- Meshwork (N, S): the combination of anastomosed rods and bars that form the external siliceous skeleton of the polycystines.

- Microsphere: see medullary shell.

- Mitral ring $(\mathrm{N})$ : in the Spyrida, the skeletal ring which lies in the plane parallel to that of the basal ring and perpendicular to that of the sagittal ring.

- Monolocular shell (N) (Figure 15.111): Nassellarian shell composed of a single segment.

- Monothalamous shell: see monolocular shell.

- Mouth $(\mathrm{N})$ : A large basal opening in the last segment of the Nassellaria (also called aperture), which can be open (Figure 3O, 3P) or obliterated by a porous plate or velum.

- Multilocular cephalis (N) (Figure 3K, 3M, 3N): cephalis provided with several chambers or lobes in addition to the eucephalic one. 
- Multilocular shell (N): see multisegmented shell.

- Multisegmented shell (N) (Figure 3O): Nassellarian shell composed of several (as opposed to one) segments.

- $\operatorname{Neck}(\mathrm{N})$ : elongated section of shell joining cephalis and thorax.

- Nodal points: see nodes.

- Nodes (N, S) (Figure 2F): area of the shell where two or more bars meet (=nodal points).

- Oral teeth: see teeth.

- Patagium (S) (Figure 2Q, 2R): a delicate, spongy meshwork in some Spongodiscidae which differs from the main shell by its looser structure.

- Peristome (N) (Figure 3P): differentiated rim around the mouth of the last segment, usually poreless, often bearing teeth or other structures.

- Phacoid shell (S): structure formed by two concentric spherical medullary shells enclosed in one lenticular cortical shell, characteristic of the families Coccodiscidae and Phacodiscidae.

- Polar caps (S) (Figure 2J): Additional skeletal growth in the form of latticed cupolae at both ends of some coccodiscid shells.

- Pore arrangement (N, S): spatial distribution of pores of the shell-wall; regular distributions can be checkered (Figure 3U) or in rows, either transversal (Figure 3S, 3T) or longitudinal (Figure 3V, 3W).

- Pores (N, S) (Figure 2D, 2E): perforations in the skeleton of the polycystines.

- Porous sieve-plate (S) (Figure 2P): a thin, perforated plate that covers the spongy surface of some Spongodiscidae.

- Post-abdominal (N) (Figure 3O): refers to

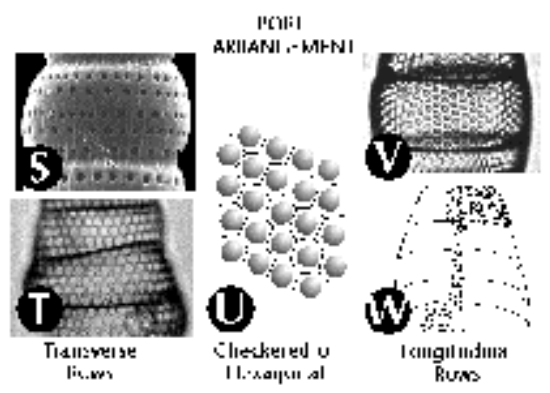
structures associated with the fourth and subsequent segments of multisegmented Nassellaria (segments, pores, ribs, etc.).

- Postcephalic lobe $(\mathrm{N})$ (Figure $3 \mathrm{~N}$ ): one of the sections into which the cephalis can be divided, sometimes elongated into a tube. 
- Primary lateral spines: see lateral spines.

- Primary spines: see spines.

- Pylome (S) (Figure 2N): A larger opening on the external shell of some Spumellaria, often extending into a tube or surrounded by larger spines.

- Radial beams: see beams.

- Ribs (N) (Figure 3Q): elongated, usually unperforated thickenings in the shellwall. Sometimes the ribs can extend into wings (Figure 3R) or feet (Figure 3Q). Dorsal and primary lateral spines embedded in the wall of the thorax can also form ribs.

- Rosette-shaped (N, S): usually applicable to pores with a tri- or tetra-lobed outline (Figure 2E).

- Sagittal plane $(\mathrm{N})$ : the plane defined by the position of the median bar (and also the apical, vertical, dorsal and axial spines).

- Sagittal ring (N) (Figure 3A): a skeletal ring formed by the median bar at the base, the vertical and apical spines at the front and back, respectively, and an arch joining these two spines at the top. It can be either free or embedded into the skeletal meshwork.

- Second shell: see first shell.

- Secondary lateral spines: see lateral spines.

- Secondary spines (= by-spines): see spines.

- Segment (N) (Figure 30): one of the several joints or sections which compose a Nassellarian skeleton, separated by the adjoining ones by an internal circular thickening of the shell-wall and/or by an external stricture.

- Septae (N): Well-developed internal divisions between the segments of nassellarian shells.

- Sieve-plate: see porous sieve-plate.

- Spines (N, S): any internal or external rod or needle with one free end. According to their relative size and number, spumellarian spines can be primary (larger, usually fewer in number; Figure 2B) and secondary (smaller, more numerous, sometimes bristle- or thorn-shaped; Figure 2B). In cross-section spines can be triangular (three-bladed) with smooth or serrated edges, or cylindrical; straight, or twisted (Figure 2G). The distal end of spines can be unbranched or branched (Figure 2G). Club-like spines have a swollen or thickened distal end (Figure 2G). Radial spines are those radiating centrifugally from the center of the shell (Figure 
2B).

- Spongy meshwork (N, S) (Figure 2N, 2O, 2P, 2Q, 2R, 2S): sponge-like (as opposed to latticed) siliceous meshwork of thin, irregular, more or less densely packed bars, mainly in some spumellarian families (Actinommidae, Spongodiscidae).

- Strictures (N) (Figure 30): joints between contiguous segments, often marked by conspicuous external constrictions.

- Teeth $(\mathrm{N})$ (Figure $3 \mathrm{P})$ : protruding apophyses around the mouth, of variable length and thickness (=oral teeth, adoral teeth, terminal teeth, subterminal teeth).

- Terminal teeth: see teeth.

- Third shell: see first shell.

- Thorax (N) (Figure 3O, 3P): second segment of multisegmented nassellarians.

- Tripod $(\mathrm{N})$ : section of the internal skeleton formed by the dorsal and primary lateral spines (Figure 3A, 3B). In some shells the tripod protrudes externally forming the feet (Figure $3 Q$ ).

- Tubercles (N, S): pustule-like lumps (condyles, mamillae) on the surface of the siliceous shell.

- Unilocular shell: see monolocular shell.

- Velum (N): a porous plate obliterating the mouth.

- Ventral spine: same as axial spine.

- Vertical spine (N) (Figure 3A, 3B): Main unpaired spine projecting from the median bar in the vicinity of the primary lateral spines and the axial spine.

- Wings (N) (Figure 3R): lateral apophyses of the thorax usually connected to the shell-wall by siliceous meshwork, derived from external projections of the dorsal and primary lateral spines.

\section{Outline classification}

The following synopsis, based chiefly on the scheme proposed by Riedel (1967b, 1971), is restricted to extant families only. As pointed out above, it is a provisional classification very likely to change as more structural and evolutionary data are obtained. Taxa in bold characters are those treated in detail in this chapter.

Kingdom PROTISTA Haeckel, 1886

Phylum SARCODINA Hertwig and Lessser, 1876 
Class ACTINOPODA Calkins, 1909

Subclass HELIOZOA Haeckel, 1886

Subclass ACANTHARIA Müller, 1858

Subclass RADIOLARIA Müller, 1858

Superorder PHAEODARIA Haeckel, 1879

Superorder POLYCYSTINA Ehrenberg, 1838, emend. Riedel, 1967

Order COLLODARIA Haeckel, 1881

Family THALASSICOLLIDA Haeckel, 1862

Family COLLOZOIDA Haeckel, 1862

Family THALASSOSPHAERIDA Haeckel, 1862

Family SPHAEROZOIDA Haeckel, 1862

Order SPUMELLARIA Ehrenberg, 1875

Family COLLOSPHAERIDAE Müller, 1858, emend. Strelkov and Reshetnjak, 1971

Family ACTINOMMIDAE Haeckel, 1862, emend. Sanfilippo and Riedel, 1980

Family COCCODISCIDAE Haeckel, 1862 emend. Sanfilippo and Riedel, 1980

Family PHACODISCIDAE Haeckel, 1881

Family SPONGODISCIDAE Haeckel, 1862, emend. Riedel 1967

Family LITHELIIDAE Haeckel, 1862

Family PYLONIIDAE Haeckel, 1881

Family THOLONIIDAE Haeckel, 1862

Order NASSELLARIA Ehrenberg, 1875

Family SPYRIDAE (=Trissocyclidae, Acanthodesmiidae) Ehrenberg, 1847, emend. Petrushevskaya, 1971

Family PLAGONIIDAE Haeckel, 1881, emend. Riedel, 1967

Family THEOPERIDAE Haeckel, 1881, emend. Riedel, 1967

Family CARPOCANIIDAE Haeckel, 1881, emend. Riedel, 1967

Family PTEROCORYTHIDAE Haeckel, 1881, emend. Riedel, 1967

Family ARTOSTROBIIDAE Riedel, 1967, emend. Foreman, 1973

Family CANNOBOTRYIDAE Haeckel, 1881, emend. Riedel, 1967

\section{Order and family-level diagnoses}

Order Collodaria. Solitary or colonial polycystines without a siliceous skeleton, or provided with simple or branched spicules scattered in the calymma. Due to their fragility, members of this group preserve poorly in net plankton samples, and either do not preserve at all or are represented only by their spicules in sedimentary materials. Partly because of these limitations, information on their classification and distribution is extremely scarce, and no further details are given herein. Detailed reviews of the colonial radiolarians, including several Collodaria, were produced by Hollande and 
Enjumet (1953), Strelkov and Reshetnjak (1971), and Swanberg (1979). Most of these species have tropical distribution ranges in the three major oceans. In the south Atlantic they are probably restricted to waters associated with the equatorial current system, the Tropics/Subtropics, and the oligotrophic Central Gyre (Figure 11). According to Haeckel (1887), this group comprises four families:

Family Thalassicollida: solitary cells, no skeletal elements; genera Actissa (Figure 15.1), Thalassocampe (Figure 15.2), Thalassopila, Thalassicolla, and Thalassophysa;

Genus Collozoida: colonial, no skeletal elements; genus Collozoum (Figure 15.6, 15.7, 15.8, 15.11);

Genus Thalassosphaerida: solitary, with siliceous spicules scattered in the calymma; genera Thalassosphaera, Thalassoxanthium (Figure 15.3), Physematium, Thalassoplancta, Lampoxanthium (Figure 15.5);

Genus Sphaerozoida: colonial, with siliceous spicules scattered in the calymma; genera Belonozoum, Sphaeorozoum (Figure 15.10), Raphidozoum (Figure 15.12).

Order Spumellaria. Solitary or colonial radiolarians with a well-developed shell of radial symmetry or one derived from the above. Variations in the type of symmetry include spiral shells (e.g., Figure 15.87), asymmetric, discoidal or lenticular (biconvex) (Figure $2 \mathrm{H}, 2 \mathrm{l} ; 15.60,15.61,15.62,15.63,15.64,15.65)$, triaxonic (Figure 2Q, 2R), quadrangular (Figure 15.66, 15.67), etc. In many cases two axes of symmetry can be clearly differentiated (Figure 2J) but, as opposed to the Nassellaria, the larger axis is homoaxonic. The central capsule (organic) of these cells has many small pores.

Family Collosphaeridae. Colonial polycystines, each individual has a single, thin-walled, spherical or subspherical latticed shell. The Collosphaeridae is the only group of colonial polycystines with complete latticed shells. Colonies consist of a gelatinous mass (which obviously disappears in the sedimentary record, as well as in many net-plankton samples where it breaks down) in which hundreds to thousands of shells are immersed (Figure 1C, 1D, 1E).

The shape of the colony is not species-specific; it may be spherical, ellipsoidal, cylindrical, ribbon-shaped, etc., measuring up to several centimeters in length and a few millimeters in diameter. The siliceous shells are always represented by a single perforated sphere (internal spheres are never present), with or without centrifugal (external) or centripetal (internal) tubular projections and/or spines. Spines (when present) are conical (circular in cross-section). As with most other polycystines, specific assignments are based almost exclusively on the skeleton; however, studies of entire colonies, which allow investigating the intraspecific morphologic variability of the 
collosphaerids, indicate that quite dissimilar shell morphotypes can coexist within the same colony, thus stressing the assumption that at least some of the specific divisions based on the siliceous sphere alone are spurious (e.g., Kleijne 1987; Petrushevskaya and Swanberg 1990).

Family Actinommidae. Solitary species with latticed or spongy spherical, subspherical, or ovoid shells (not lenticular); with or without medullary shells. Surface of shell is often covered with spines, but not tubes. All actinommids posses either single or multiple, concentric spherical or ovoid shells. When several shells are present they are connected to each other by radial beams which pierce the cell. An enormous variety of forms was described in this family whose identification has traditionally been based on Haeckel's (1887) system. Haeckel based the classification of the actinommids (=suborder Sphaeroidea, exclusive of the Collosphaerida) on the following characters (in decreasing order of importance; see Figure 13): 1. Number of primary radial spines; 2 . Number of concentric spheres; 3 . Position of concentric spheres (intra- or extracapsular), type and relative size of spines, presence of by-spines, type of medullary shell, etc.). However, the number of primary spines varies intraspecifically, whereas the number of main concentric spheres, which within some bounds might indeed be species-specific (Riedel and Sanfilippo 1986), can only be used in the case of fully-grown individuals. It is quite obvious that, based on this trait, Haeckel (as well as many other authors) assigned new names to growth stages still missing the outermost sphere(s) (see Figs. 13 and 14). Furthermore, while growth of an actinommid as far as we know proceeds from the center toward the periphery (Figure 14, upper panel), dissolution works in the opposite direction, innermost, more delicate shells usually disappearing before the more robust cortical ones. Thus, materials from the sediments offer yet another suite of "new species", this time missing the medullary (rather than the cortical) shells.

Family Coccodiscidae (Figure $2 \mathrm{H}, 2 \mathrm{~J}$ ). Latticed discoidal or lenticular shell enclosing a single or double medullary shell, and surrounded by an equatorial zone of spongy or concentrically-chambered structures (Figure $2 \mathrm{H}$ ), or forms with an ellipsoidal cortical shell equatorially constricted enclosing a single or double medullary shell (Figure 2J). The formerly actinommid subfamily Artiscinae was transferred to the Coccodiscidae by Sanfilippo and Riedel (1980) due to its phylogenetic affinities with extinct coccodiscids.

Family Phacodiscidae. Lenticular, biconvex, latticed cortical shell, not surrounded by spongy or chambered structures, within which a small, spherical single or double medullary shell is enclosed. The margin (but less commonly the surfaces) of the cortical shell may bear radial spines.

Family Spongodiscidae. Discoidal or cylindrical, spongy or finely chambered skeleton, with or without surficial pore-plate, often with radiating arms or marginal spines. The members of this family are characterized by possessing skeletons which are partly or entirely spongy in appearance. However, as opposed to the 
Actinommidae, which can also have spongy skeletons, the Spongodiscidae are not spherical. Their overall shape can be lenticular (biconvex discs, Figure 2l), cylindrical (Figure 15.74), quadrangular or subquadrangular in outline (Figure 15.67), or Y-shaped (Figure 2Q, 2R). With the exception of the cylinders, all others are depressed or flattened (rather than circular in cross-section, Figure 2I). Lenticular, quadrangular, and Y-shaped forms may be entirely composed of a spongy mass with no discernible structure (in which case the central part of the skeleton is often thicker and/or denser, and therefore appears darker in the light microscope; Figure 2O, 15.64), or may posses a small central chamber surrounded by concentric or spiral, continuous or interrupted bands (Figure 2R). The surface of some forms may be partly or totally covered with a very thin, porous sieve-plate, which in lenticular forms may extend beyond the central spongy mass forming a delicate equatorial girdle around the periphery of the shell (Figure 2P) (these morphotypes were formerly included in the family Porodiscidae).

Family Litheliidae. The lattice of the ellipsoidal, spherical or lenticular shell is totally or partially arranged along a bilaterally symmetrical spiral. Although very abundant, due to their complicated architecture the litheliids are poorly known, for which reason the morphotypes defined may include several different forms.

Family Pyloniidae. The major part of the shell is composed of a series of successively larger elliptical latticed girdles in three mutually perpendicular planes, with the major diameter of each girdle being the minor diameter of the next larger one (Figure 2L, 2M). The center is occupied by a small ellipsoidal structure - the microsphere (see Dumitrica 1989).

Family Tholoniidae. Completely latticed shell, without larger openings, and with constrictions that define several (typically 6) dome-shaped protuberances (Figure 2K).

Order Nassellaria. Solitary polycystines with a siliceous heteropolar shell, which can be represented by several fused spicules only, by a D-shaped ring and associated spines, or by

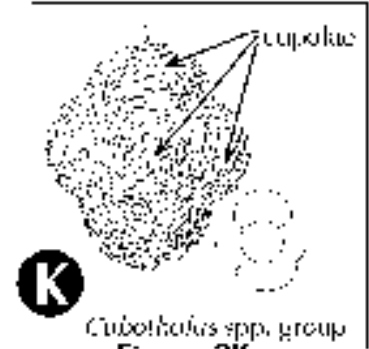

Figure 2K. more elaborate, mono- or multilocular latticed skeletons. With the exception of a few forms lacking a well developed skeleton (Figure 15.101, 15.119), the symmetry of this group is characterized by the fact that the two extremes of the major axis define two morphologically different poles of the shell. One of these, conventionally accepted as the top or anterior end, is where the cephalis is located. A widely recognized, albeit seldom utilized, feature of primary importance for the classification of the Nassellaria is the internal skeleton. The internal skeleton consists of a complex set of spines and connecting bars enclosed in the cephalis (Figure 3A, 3B, 3C), which allow comparison of homologous structures in forms differing widely in their external morphology. Unfortunately, analysis of these features requires dedicated efforts at 
understanding the complex spatial relationships involved. Furthermore, observation of this internal skeleton is only feasible with well preserved individuals oriented in the right position, which is seldom the case in specimens mounted in permanent slides. In addition to the small scattered perforations typical of the Spumellaria, the central capsule of the Nassellaria is usually provided with a single larger pore.

Family Spyridae (=Trissocyclidae). The skeleton is represented by a welldeveloped D-shaped sagittal ring (median bar and anastomosed vertical and apical spines), either free (Figure 15.101) or embedded into the latticed cephalic wall, in which case the cephalis is usually bilaterally lobed (Figure 15.93, 15.94, 15.100). Sometimes with thorax, abdomen always absent. The typical heteropolar nassellarian symmetry is often inconspicuous in the Spyridae.

Family Plagoniidae. Skeletons restricted to a simple tri- or tetraxonic nassellarian spicule (Figure 15.119), or a well developed system of main spines enclosed within a fully formed cephalis (Figure 3A, 3B). The degree of development of the cephalis may vary from a few anastomosed bars (Figure $15.120,15.124$ ) to a well developed, latticed or latticed/spongy chamber. Usually without postcephalic segments. In addition to several fairly well-defined species, the Plagoniidae comprise many probably related forms of obscure taxonomic status usually cited under various generic names (see below). The classification of these forms needs detailed ad hoc studies, for which reason many of them are provisionally lumped under the designation Plagoniidae group in the present chapter.

Family Theoperidae. Cephalis spherical or subspherical, relatively small, often poreless or sparsely perforate. It usually bears an apical horn. Internal spicule small and inconspicuous. With one or more, sometimes up to over 10, usually well-developed postcephalic segments. Generally, cap- or helmet-shaped, or conical in overall outline.

Family Carpocaniidae. The small, rudimentary cephalis is usually totally immersed in the large and well-developed thorax (Figure 3E). Abdomen absent or rudimentary.

Family Pterocorythidae. Cephalis large, divided into three lobes by two lateral furrows directed obliquely and downward from the apical spine to the base of the cephalis. The upper unpaired lobe is located above the two smaller paired ones (Figure 3K, 3L); these basal paired lobes are not always conspicuous. Many pterocorythids are two or three-segmented, lacking postabdominal segments.

Family Artostrobiidae. Spherical or subspherical cephalis, usually with an apical tube directed obliquely upwards (Figure $3 \mathrm{~J}$ ). The pores on all postcephalic segments, or at least on the last ones, are arranged in clearly defined transverse rows (Figure 3S). Usually elongated, multisegmented forms.

Family Cannobotryidae. Cephalis large, with several asymmetrical lobes 
(sometimes appearing as irregular bulges) (Figure 3M). Mostly 2-segmented forms (cephalis and thorax), but sometimes with post-thoracic segments.

\section{TAXONOMY}

\section{Identification of species}

The overall total of living polycystine species is probably around 300-600, but this review includes only 164 taxa. Unfortunately, our present state of knowledge is insufficient for a significantly greater coverage. All polycystine families need detailed taxonomic work, but some are especially poorly known (e.g., Actinommidae, Pyloniidae, Litheliidae, Tholoniidae, Plagoniidae). However, the inexperienced student should not be discouraged by the fact that the available literature fails to assist in identifying very significant proportions of the shells present in any given sample. As mentioned above, most radiolarian-based ecological and paleoecological surveys restrict their scope to some 20-40 polycystines, the rest being ignored altogether. Although coverage of an ampler inventory is clearly desirable, these restricted databases allow one to draw very valuable environment-related conclusions. Furthermore, in order to circumvent identification-related problems, the use of family-level assignments has been advocated for environmental and biogeographic analyses (Kruglikova 1981, 1987).

The following section presents succinct information for the identification of the taxa recorded in the South Atlantic Ocean, as well as for several others whose presence in the area is very likely, but has not been confirmed yet.

When applicable, species names are followed [in square brackets] by some of the other most common names under which the form has been recently cited in the literature. Diagnostic information is provided as short remarks stressing the characters which help differentiate the taxon from closely related forms; they are not meant to replace detailed descriptions, but in most cases these remarks, in combination with the illustrations, should suffice for producing adequate identifications of the radiolarians treated. Keys are not adequate for this particular group due to their lack of flexibility, and because they are more prone to lead to misidentifications given the high number of rare polycystine species not included in this review. Shell size is generally of minor value for identification purposes, for which reason no detailed morphometric information is given; the dimensions specified are approximate and are furnished with the sole purpose of a general scale reference. The designation "group" denotes categories of unclear taxonomic affinities, where probably several related taxa are lumped. For each of the species treated one or more references ("Ref.") providing detailed descriptions and illustrations are included. 


\section{Order Spumellaria}

\section{Family Collosphaeridae}

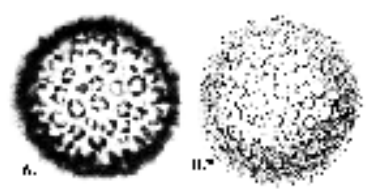

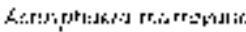

Figure 15.19.

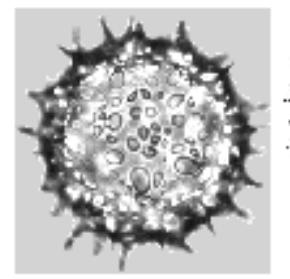

A.

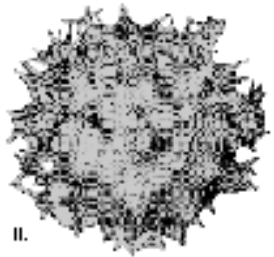

Acrosphoera spinoso group?

Figure 15.18.

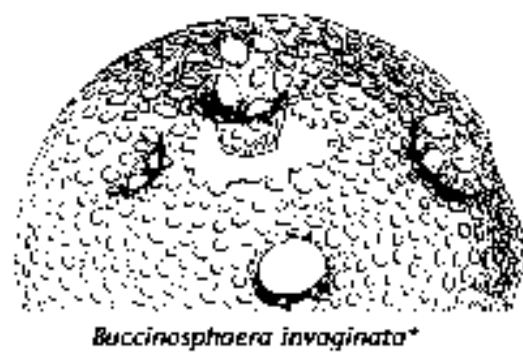

Figure 15.17".
Acrosphaera murrayana (Haeckel) (Figure 15.19) [=Polysolenia murrayana]. Large pores, each surrounded by a crown of short spines. Shell diameter: 70-180 $\mu \mathrm{m}$. Ref: Strelkov and Reshetnjak (1971), Nigrini and Moore (1979).

Acrosphaera spinosa (Haeckel) group? (Figure 1D, 15.18) [=Polysolenia spinosa, ?P. lappacea, ?P. flammabunda]. Irregular pores and many irregularly arranged spines scattered about the surface, some of the latter extending from the pore-rims. Spine and pore patterns are variable. Shell diameter: 60-160 $\mu \mathrm{m}$. Ref: Strelkov and Reshetnjak (1971), Boltovskoy and Riedel $\underline{(1980)}$.

Buccinosphaera invaginata Haeckel (Figure 15.17) [=Collosphaera imvaginata]. The smooth shell produces several pored tubes directed toward the center of the sphere. Rather small, irregular pores. Shell diameter: 100-130 $\mu \mathrm{m}$. Ref: Strelkov and Reshetnjak (1971), Nigrini $\underline{(1971)}$. 

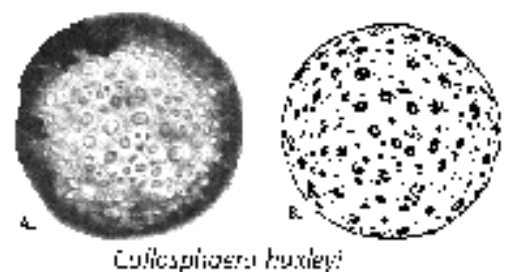

Cuiliciviost: buxie

Figure 15.13.

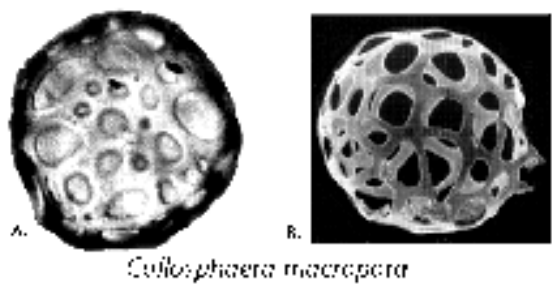

Figure 15.15.

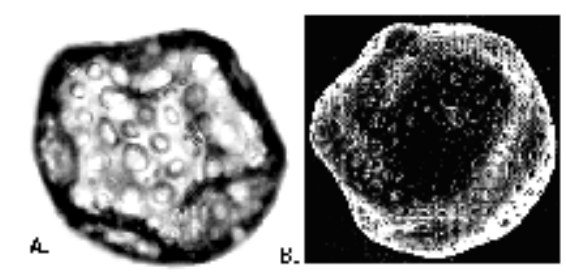

Colksphaera tuberosa

Figure 15.14.

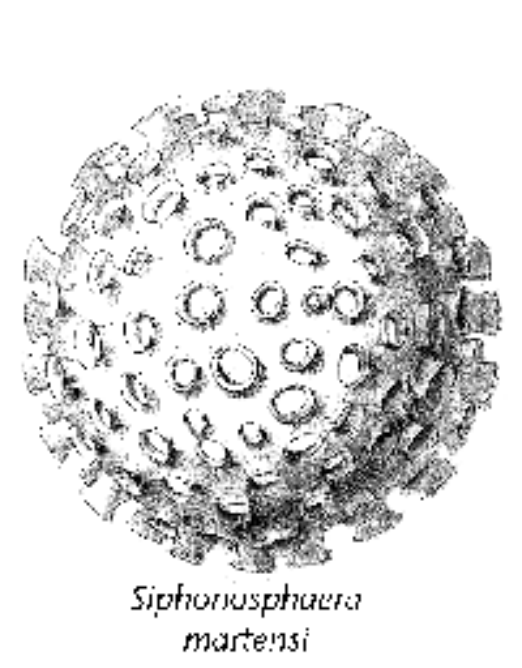

Figure 15.20.
Collosphaera huxleyi Müller (Figure 1E, 15.13). Shells with small to medium-sized pores scattered about the surface only; no spines or tubes. Shell diameter: 80-150 $\mu \mathrm{m}$. Ref: Strelkov and Reshetnjak (1971), Boltovskoy and Riedel (1980).

Collosphaera macropora Popofsky (Figure 15.15). No spines or tubes on shell surface; few very large pores, sometimes angular. Shell diameter: 100-120 $\mu \mathrm{m}$. Ref:

Strelkov and Reshetnjak (1971), Boltovskoy and Riedel (1980).

Collosphaera tuberosa Haeckel (Figure 15.14). No spines or tubes on shell surface, but with conspicuous lumps and depressions; many small, irregularly shaped pores. Shell diameter: 50-300 $\mu \mathrm{m}$. Ref: Strelkov and Reshetnjak (1971), Boltovskoy and Riedel (1980).

Siphonosphaera martensi Brandt (Figure 15.20). Each pore bears a short centrifugal tube, tube walls are imperforate. Shell diameter: 90-100 $\mu \mathrm{m}$. Ref: Strelkov and Reshetnjak (1971). 


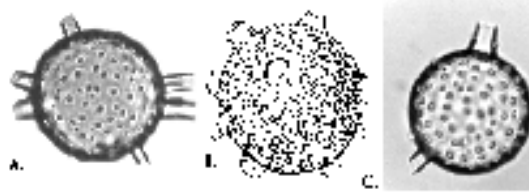

Siphonasphaero polysiphonia

Figure 15.23.

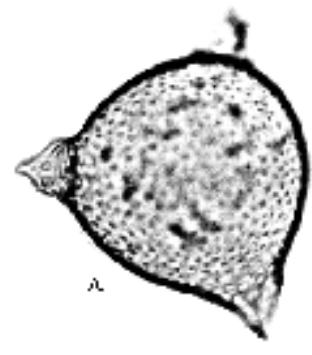

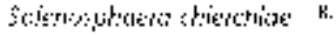

Figure 15.22.

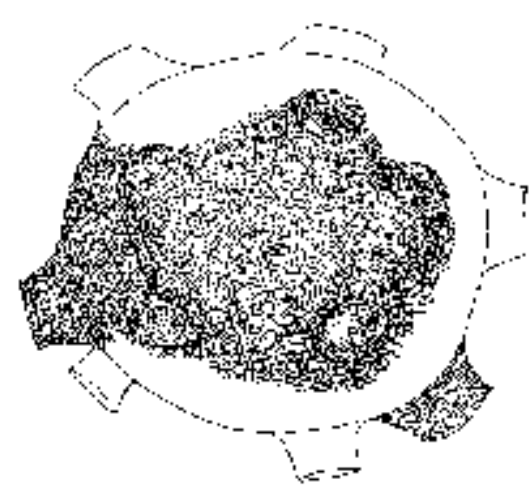

Solenosphaera polysolenia

Figure 15.21".

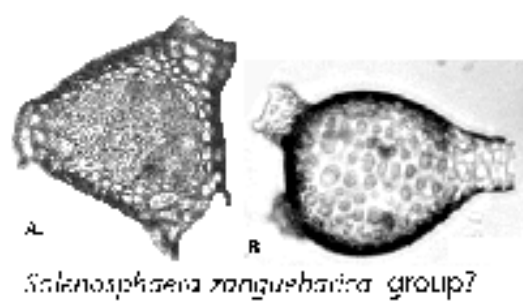

Figure 15.24.
Siphonosphaera polysiphonia Haeckel (Figure 15.23) [=Siphonosphaera socialis, ?Siphonosphaera tenera]. Tubes of variable length are present on some of the pores, tube walls are imperforate. According to Strelkov and Reshetnjak (1971) S. socialis Haeckel has usually smaller shells $(50-80 \mu \mathrm{m})$. Shell diameter: 80-120 $\mu \mathrm{m}$. Ref: Nigrini and Moore (1979), Boltovskoy and Riedel (1980).

Solenosphaera chierchiae Brandt (Figure 1C, 15.22) [=Otosphaera polymorpha]. The shell bears three-four (up to six) short tubes with perforated walls whose distal end is tapered, ending in a slanted pore provided with one-two conspicuous spines. Shell diameter: 65-100 $\mu \mathrm{m}$. Ref: Strelkov and Reshetnjak (1971), Nigrini and Moore (1979).

Solenosphaera polysolenia Strelkov and Reshetnjak (Figure 15.21). With many (rather than three-five, as in Solenosphaera zanguebarica) short tubes with perforated walls, and smaller, more angular pores. Shell diameter: 90-280 $\mu \mathrm{m}$. Ref: Strelkov and Reshetnjak (1971).
Solenosphaera zanguebarica (Ehrenberg) group?

(Figure 15.24) [=Solenosphaera polymorpha, Otosphaera polymorpha, Disolenia zanguebarica, ?Disolenia quadrata]. General outline of shell often subtrianguar, the vertices extending into three-four short tube-like protrusions with perforated walls and open ends. The rim of these tubes may bear spines. Pores irregular in shape and size, but generally roundish or subangular. A morphotype very similar to $S$. zanguebarica (and most probably conspecific with it), usually cited as Disolenia quadrata (Ehrenberg) (Figure 15.24a), differs by having 


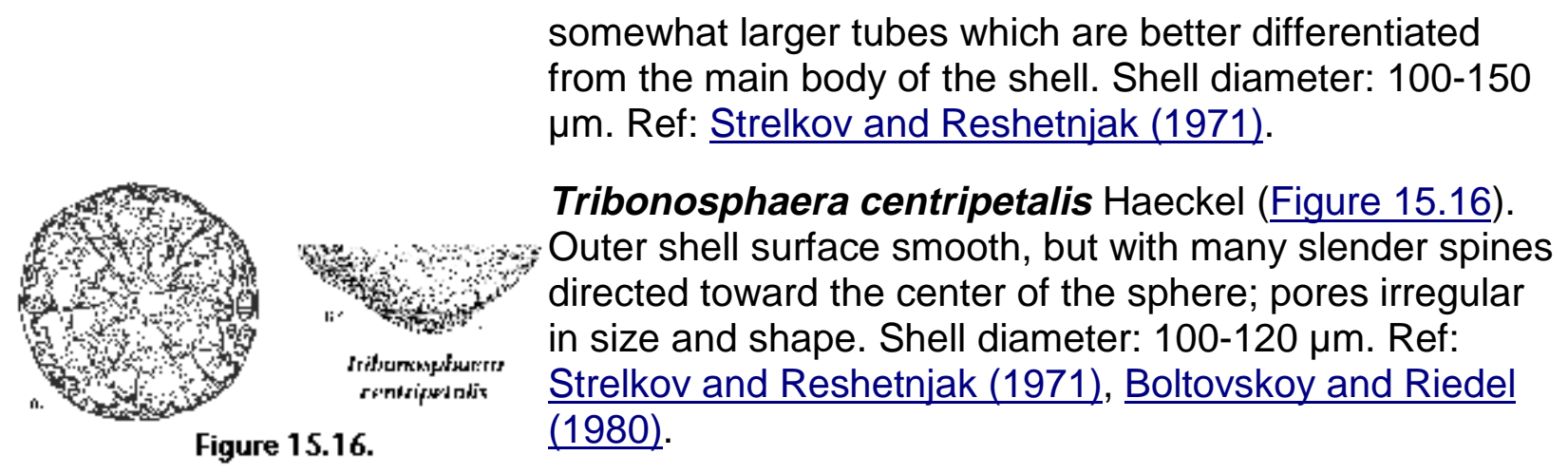




\section{Order Spumellaria}

\section{Family Actinommidae}

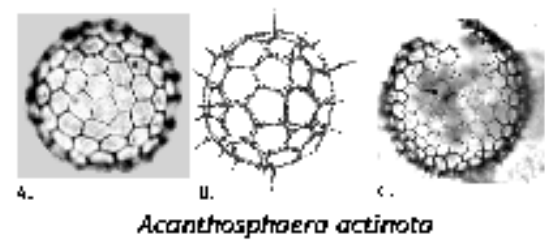

Figure 15.25.

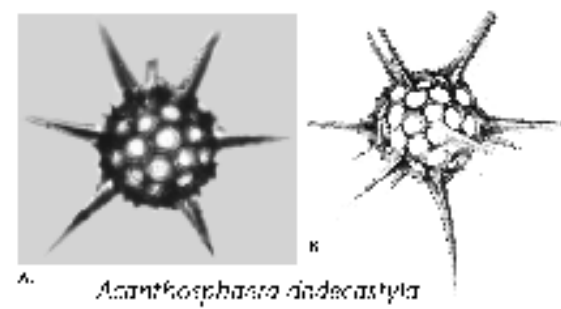

Figure 15.26.

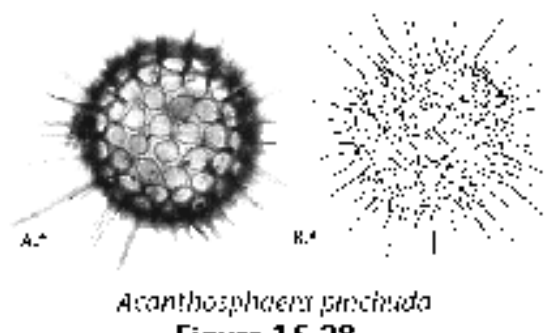

Figure 15.28.
Acanthosphaera actinota (Haeckel) (Figure 15.25) [=Acanthosphaera tenuissima]. Single shell with large, regular polygonal meshes separated by very thin bars. Nodal points bear short, bristle-shaped spines; no primary (conspicuously larger) radial spines (broken-off on specimen photographed). Shell diameter: 60-90 $\mu \mathrm{m}$. Ref: Boltovskoy and Riedel (1980).

Acanthosphaera dodecastyla Mast (Figure 15.26). Single shell with large circular pores with very conspicuous polygonal frames, many (10-20) robust, three-bladed spines. Shell diameter without spines: 50$80 \mu \mathrm{m}$. Ref: Popofsky (1913), Boltovskoy and Riedel (1980).

Acanthosphaera pinchuda Boltovskoy and Riedel (Figure 15.28). Single shell with regular, subcircular pores surrounded by conspicuous protruding frames which extend into thin, thread-like spines at the nodal points. No primary (conspicuously larger) radial spines. Shell diameter without spines: 90-120 $\mu \mathrm{m}$. Ref: Boltovskoy and Riedel (1980). 

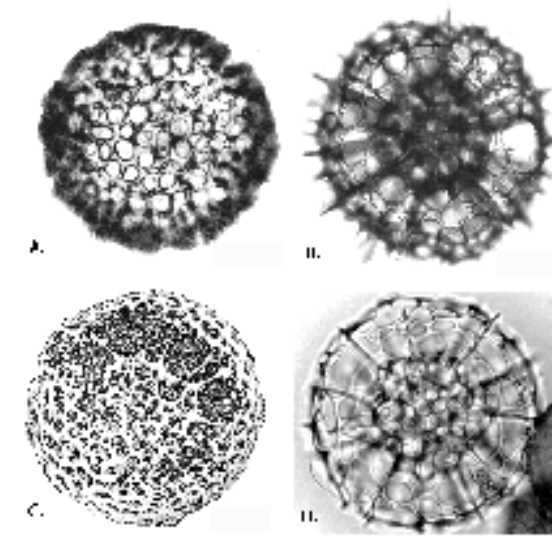

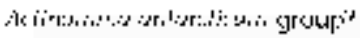

Figure 15.48.

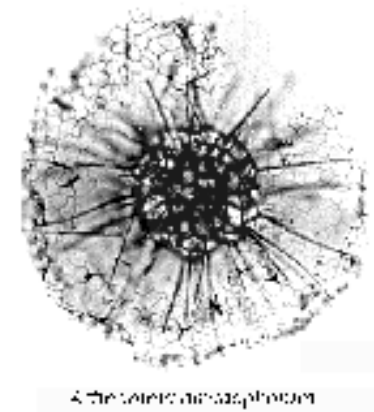

Figure 15.49.

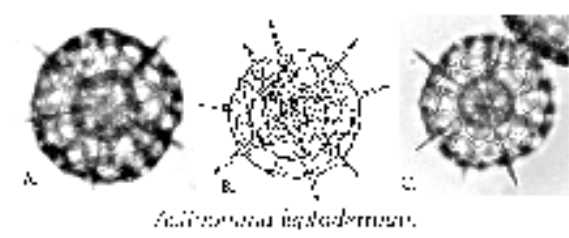

Figure 15.37.

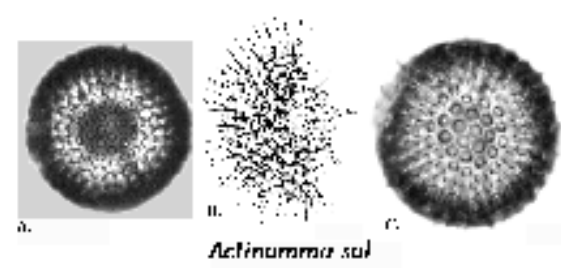

Figure 15.44.
Actinomma antarcticum (Haeckel) group? (Figure 15.48) [=Diploplegma banzare, Diploplegma aquatica]. Three concentric shells. Cortical shell composed of a very irregular, sometimes sponge-like network of thick anastomosing bars. Second shell large, irregularly shaped, spongy. First shell small, circular, rarely visible. Nigrini (1967) described Actinomma medianum, which differs from $A$. antarcticum in that it has a simply latticed cortical shell and a more delicate medullary meshwork. Cortical shell diameter: 200-400 $\mu \mathrm{m}$. Ref: Riedel (1958), Nigrini (1967).

Actinomma arcadophorum Haeckel (Figure 15.49). Medullary shells similar to Actinomma antarcticum; cortical shell is composed of an irregular, sponge-like or lace-like network of very thin, delicate anastomosing bars. Cortical shell diameter: 200-250 $\mu \mathrm{m}$. Ref: Haeckel (1887), Nigrini and Moore (1979).

Actinomma leptodermum (Jorgensen) (Figure 15.37) [=Echinomma leptodermum]. Three concentric shells, pores on outermost shell relatively large, subcircular, irregularly arranged; surface covered by numerous short three-bladed spines; no primary (conspicuously larger) radial spines. Outermost shell diameter without spines: 60-120 $\mu \mathrm{m}$. Ref: Nigrini and Moore (1979).

Actinomma sol Cleve (Figure 15.44) [= Thecosphaera radians]. Three concentric shells. Outermost with regular, circular pores with well developed polygonal frames, usually bearing short bristle-shaped spines on the nodes (broken off in the specimen photographed); no primary (conspicuously larger) radial spines (see remark for Thecosphaera inermis). Outermost shell diameter: 70$100 \mu \mathrm{m}$. Ref: Hollande and Enjumet (1960), Boltovskoy and Riedel (1980). 


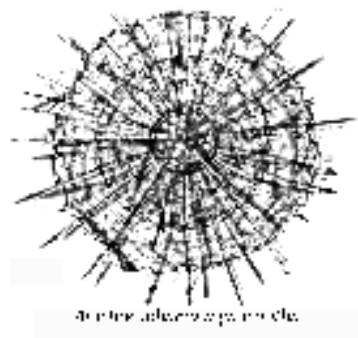

Figure 15.45.

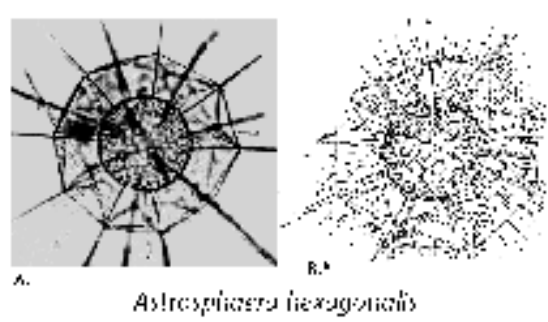

Figure 15.40.

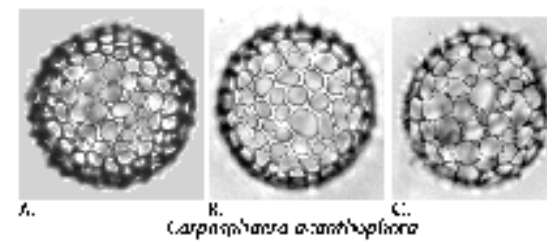

Figure 15.39.

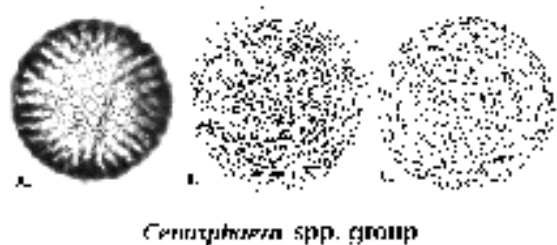

Figure 15.29.
Arachnosphaera myriacantha Haeckel (Figure 15.45). Fully grown specimens with many (up to over seven; four in the specimen illustrated) concentric spheres, the innermost with regular hexagonal meshes and cylindrical spines arising from the nodes. At regular distances these spines produce branches which anastomose laterally forming subsequent spheres with a delicate, irregular, cobweb-like network. Branching spines protrude from the surface of the last shell. Diameter of innermost shell: ca. $100 \mu \mathrm{m}$. Ref: Haeckel (1862).

Astrosphaera hexagonalis Haeckel (Figure 15.40). Two shells and many $(>6)$ primary radial spines. Inner shell with regular polygonal meshes and thin bars. Outer shell with very large, triangular meshes formed by anastomosing of lateral branches produced by the long, three-bladed primary spines arising from the first shell. Spines extend beyond the very open outer shell. Diameter of inner shell: $150 \mu \mathrm{m}$. Ref: Haeckel (1887).

Carposphaera acanthophora (Popofsky) (Figure 15.39). One latticed cortical shell and one medullary shell represented by an irregular formation of anastomosing centripetal bars arising from the cortical shell (may be missing in poorly preserved materials; not focused in specimen illustrated). Pores on outer shell irregular in shape and size, generally subcircular. Surface rough or thorny. Diameter of cortical shell: 150-270 $\mu \mathrm{m}$. Ref: Benson (1966).

Cenosphaera spp. group (Figure 15.29) [=Cenosphaera elysia, C. compacta, C. hirsuta]. Single sphere, often thick-walled. Pores more or less regular, circular, or irregular, of variable shape and size, with or without polygonal frames, with or without thin, bristle-shaped byspines or thorns. No primary (conspicuously larger) radial spines. Highly variable group with many different morphotypes present chiefly in middle and high latitudes (e.g., C. cristata Haeckel in Antarctic waters, cf. Petrushevskaya 1967; C. compacta Haeckel and C. elysia Haeckel in subantarctic-transitional areas, cf. Boltovskoy and Riedel 1980). Shell diameter: 50-320 $\mu \mathrm{m}$. Ref: Petrushevskaya (1967), Boltovskoy and Riedel (1980). 


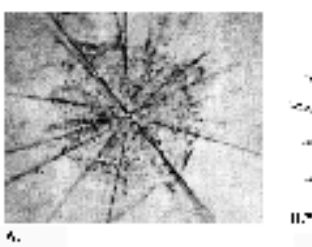

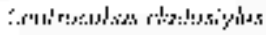

Figure 15.58.

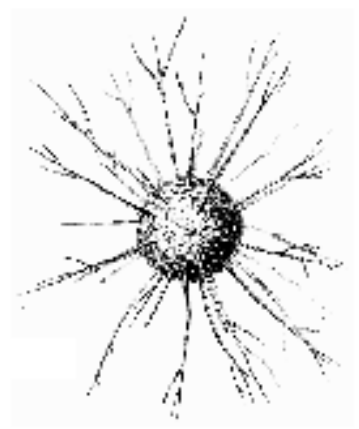

codacowers cerwicomss

Figure 15.41.

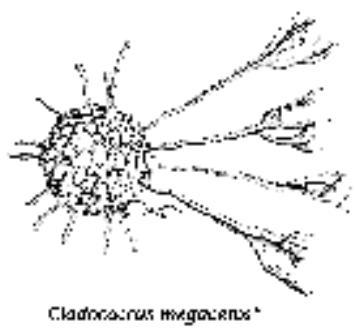

Figure 15.42."

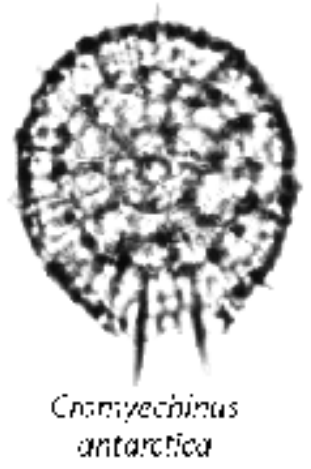

Figure 30.
Centrocubus cladostylus Haeckel (Figure 15.58). Medullary shell single, composed of bars that define a small cube (Figure 2C); cortical shell a spongy meshwork arising immediately from the medullary shell, supported by many large, three-bladed spines that protrude outside of the spongy mass. Cortical shell diameter without spines: 150-200 $\mu \mathrm{m}$. Ref: Haeckel (1887).

Cladococcus cervicornis Haeckel (Figure 15.41). Single shell with very irregular sub-polygonal pores; at many nodal points slightly curved, cylindrical spines project radially dichotomizing repeatedly starting about $2 / 3$ of the way from the cortical shell. Shell diameter without spines: ca. $70 \mu \mathrm{m}$. Ref: Boltovskoy and Riedel (1980).

Cladococcus megaceros Hollande and Enjumet (Figure 15.42). Similar to Cladococcus cervicornis, differs in that spines can be three-bladed, thickening toward their distal end; branches are short and dull, resembling the horns or a reindeer. Pores are more irregular in size and shape. Shell diameter without spines: ca. $60 \mu \mathrm{m}$. Ref: Hollande and Enjumet (1960), Boltovskoy and Riedel (1980).

Cromyechinus antarctica (Dreyer) (Figure 5A, 5A', 14, 15.30). Fully grown specimens with four concentric, latticed shells. Outermost thin-walled, with very small pores. Third shell thicker, with large, irregularly shaped pores. Surface covered with many short, stout, threebladed spines, at one of the poles spines may be denser and larger, forming a pylome. Major diameter of outermost shell: 100-160 $\mu \mathrm{m}$. Ref: Petrushevskaya (1967). 

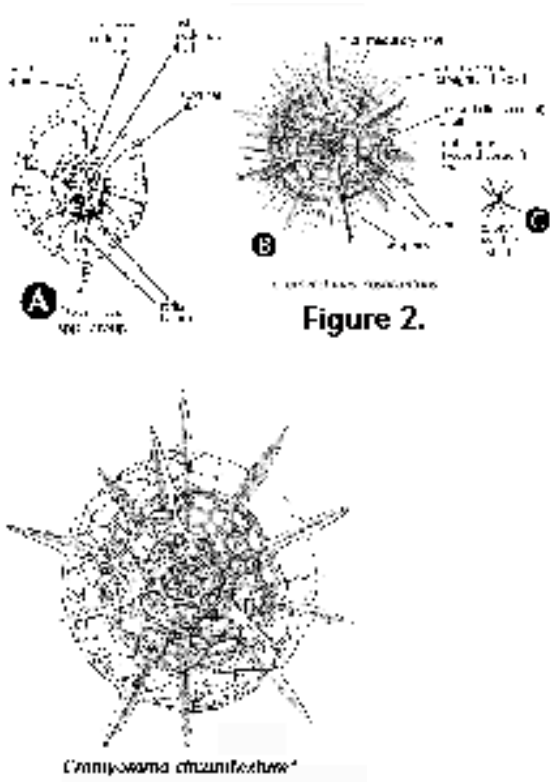

Figure 15.47.*

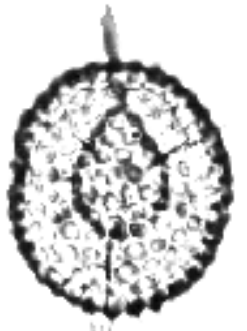

A.
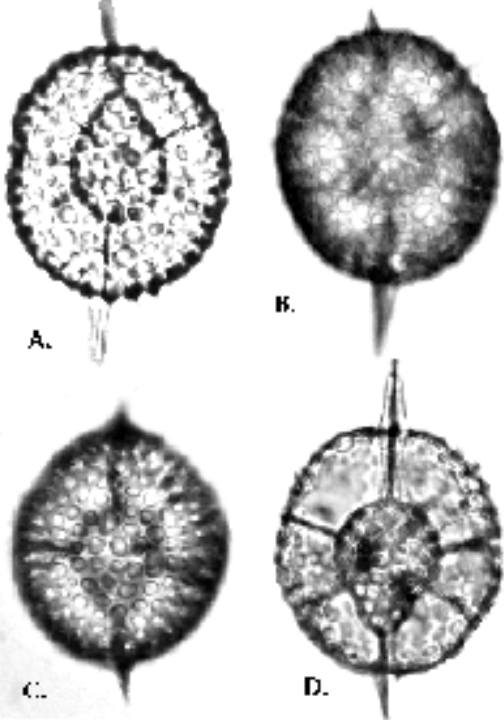

Druppatractus irregulicris

Figure 15.27.

Cromyechinus icosacanthus Haeckel (Figure 2B). Fully grown specimens with four latticed concentric shells and many (>6) stout, three-bladed spines. Outermost shell thin-walled, delicate, with very small, regular, circular pores. Third shell with large, irregular, polygonal pores. Outermost shell diameter without spines: ca. 160 $\mu \mathrm{m}$. Ref: Haeckel (1887).

Cromyomma circumtextum Haeckel (Figure 15.47). Fully grown specimens with four latticed concentric shells and many three-bladed spines of irregular size and distribution. Outermost shell very delicate, thin-walled, with thread-like bars and large, irregular, polygonal meshes; third shell with large, irregular pores and thick bars. Due to its delicacy, the fourth shell is very likely to be absent in sedimentary materials, in which case this species may be identified as Hexalonche aristarchi (see below). Outermost shell diameter without spines: ca. 220 $\mu \mathrm{m}$. Ref: Haeckel (1887).

Druppatractus irregularis Popofsky (Figure 15.27). Two latticed shells, outermost thin-walled, smooth, with small regular, circular pores; medullary shell pear-shaped. Two main polar spines of equal or different size (additional, usually smaller spines may be present as well). Cortical shell diameter without spines: ca. $80 \mu \mathrm{m}$. Ref: Benson (1966). 


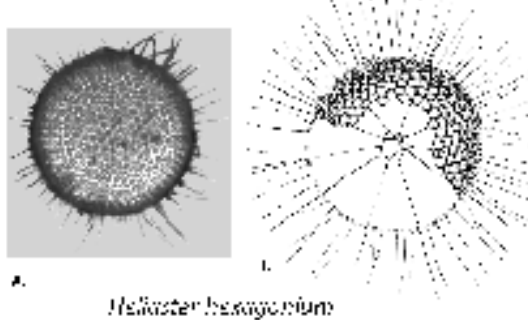

Figure 15.46.

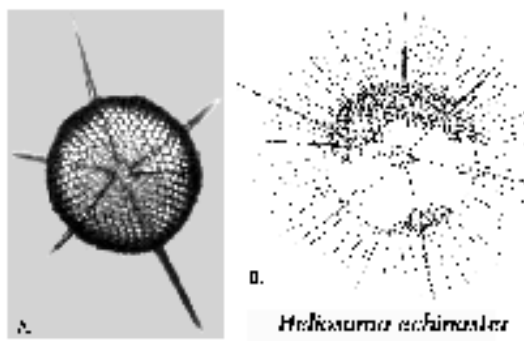

Figure 15.43.

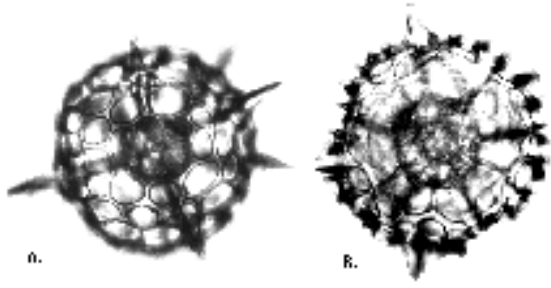

tiexacontium ulist:arcin:

Figure 15.33.

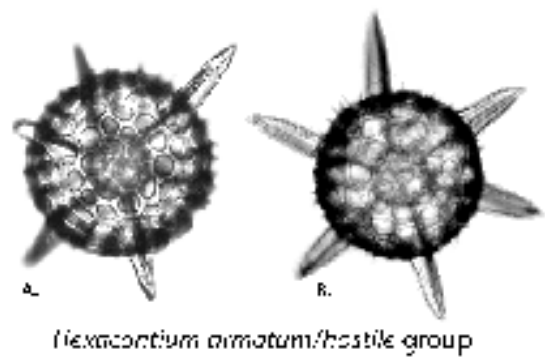

Figure 15.32.
Heliaster hexagonium Hollande and Enjumet (Figure 15.46). Two latticed shells, medullary as in Carposphaera acanthophora (may be missing in poorly preserved materials). Pores on cortical shell very regular, polygonal, with thin bars; bristle-shaped spines on nodes. Outer shell diameter without spines: ca. $230 \mu \mathrm{m}$. Ref: Hollande and Enjumet (1960).

Heliosoma echinaster Haeckel (Figure 15.43) [=Tetrapetalon elegans]. Two concentric shells. Medullary shell composed of a loose network of thin anastomosing bars. Outer shell similar to that of Heliaster hexagonium, except for the presence of many $(>6)$ long, three-bladed primary spines. Outer shell diameter without spines: ca. $160 \mu \mathrm{m}$. Ref: Hollande and Enjumet (1960).

Hexacontium aristarchi (Haeckel) (Figure 15.33) [=Hexalonche aristarchi]. Similar to Hexacontium armatum/hostile, except that pores on outermost shell are larger and more irregular in size and distribution. May have one medullary shell (?). It is probable that $H$. aristarchi is a developmental form of Cromyomma circumtextum, from which it differs by lacking the outermost, very slender and delicate fourth shell. Outermost shell diameter without spines: ca. $130 \mu \mathrm{m}$. Ref: Boltovskoy and Riedel (1980).

Hexacontium armatum/hostile Cleve group (Figure 15.32). [= Hexacontium armatum, Hexacontium hostile, ?Hexacontium entacanthum]. Three concentric latticed shells; surface of outermost usually thorny or spiny, pores medium-sized, regular or irregular in size and distribution, with or without polygonal frames. Usually 6 main spines opposite in pairs in three dimensive axes perpendicular to one another. Outermost shell diameter without spines: 70-100 $\mu \mathrm{m}$. Poorly defined morphotype, probably includes several related species. Ref: Boltovskoy and Riedel (1980). 


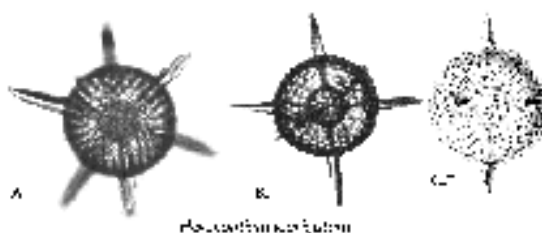

Figure 15.31.

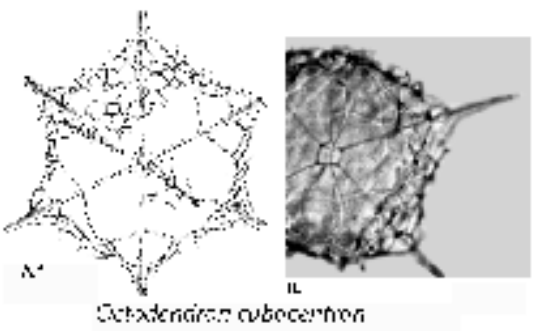

Figure 15.56.

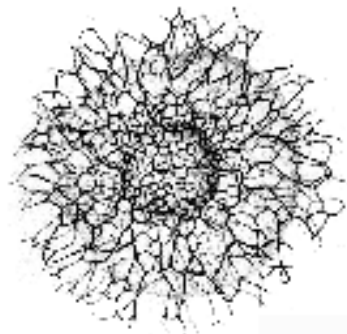

"ietemzsoritert er:'iudicilyuri

Figure 15.54.

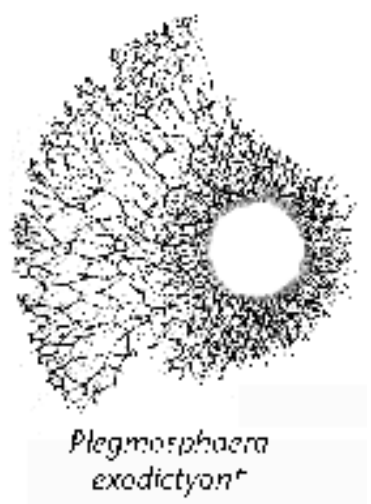

Plegmosphaera exodictyon Haeckel (Figure 15.55). Similar to Plegmosphaera entodictyon, except that the spongy meshwork is denser both in the vicinity of the central cavity and at the periphery of the shell, and looser midway. Shell diameter: ca. $400 \mu \mathrm{m}$. Ref: Haeckel (1887).

Figure 15.55.* 


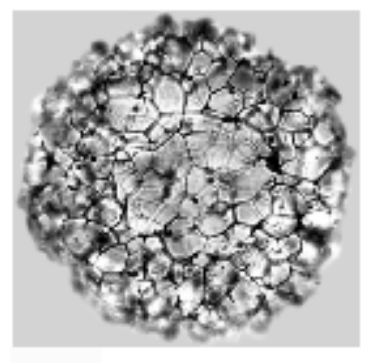

"

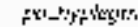

Figure 15.53.

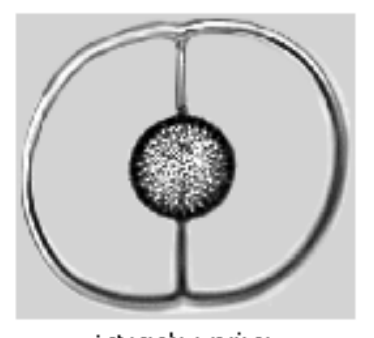

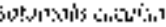

Figure 15.36.

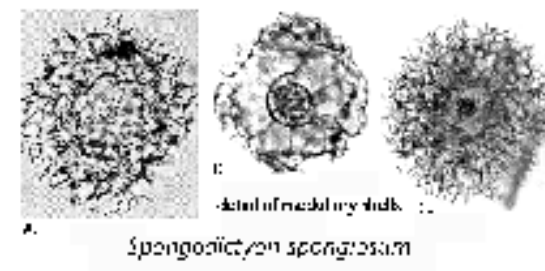

Figure 15.57.

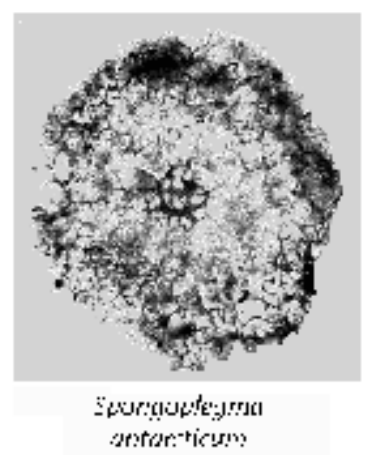

Figure 15.51.
Plegmosphaera pachyplegma Haeckel (Figure 15.53). Similar to Plegmosphaera entodictyon, except that the spongy meshwork is denser at the periphery of the shell than in the vicinity of the central cavity. Shell diameter: ca. $200 \mu \mathrm{m}$. Ref: Hollande and Enjumet (1960).

Saturnalis circularis Haeckel (Figure 15.36). Two concentric latticed shells, the cortical with circular to subcircular pores and rough surface. Two primary radial polar spines (which extend as internal beams joining the two shells) joined distally by a circular ring. Cortical shell diameter without spines: 70-80 $\mu \mathrm{m}$. Ref: Nigrini (1967).

Spongodictyon spongiosum (Müller) (Figure 15.57) [=Dictyosoma spongiosum]. Generally similar to Spongoplegma rugosa, except that center hosts a double medullary shell; second medullary shell usually incompletely developed. Outermost shell diameter: 200 $\mu \mathrm{m}$. Ref: Müller (1858).

Spongoplegma antarcticum Haeckel (Figure 15.51). Spongy mass with a single irregular, sponge-like medullary shell in the center. Outer shell diameter: ca. $150 \mu \mathrm{m}$. Ref: Boltovskoy and Riedel (1980). 


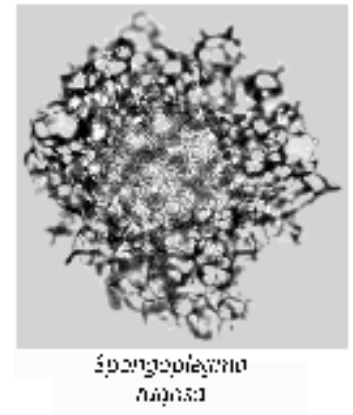

Figure 15.52.

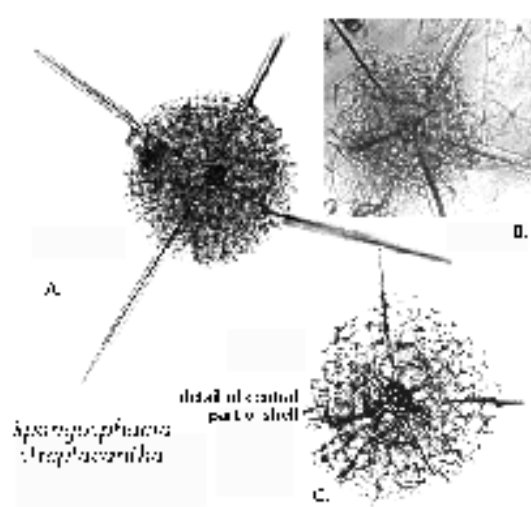

Figure 15.59.

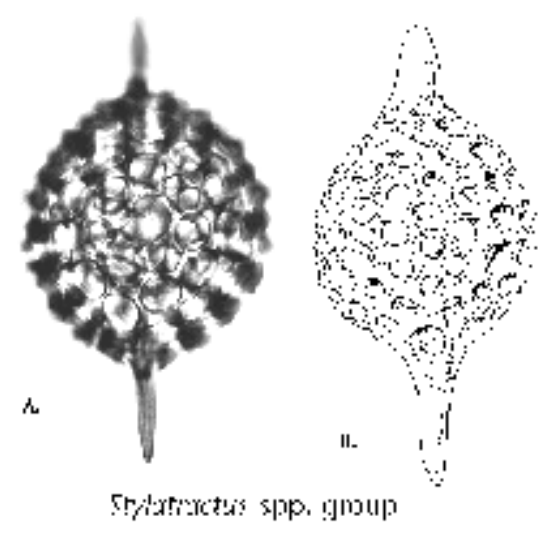

Stylatractus spp. group (Figure 2A; 15.35). [= ?Stylatractus, ?Axoprunum, ?Stylosphaera, ?Xiphosphaera, ?Lithatractus, ?Xiphatractus]. Usually two latticed shells, outermost spherical to oval-shaped, often thick-walled with irregular pores; medullary shell spherical. Two polar spines of equal or different size, with or without secondary spines. Two-spined and usually two-shelled actinommids comprise a large, sometimes abundant, highly variable and very poorly studied group. Outer shell diameter without spines: 100-150 $\mu \mathrm{m}$. Ref: Nigrini and Moore (1979).

Figure 15.35. 

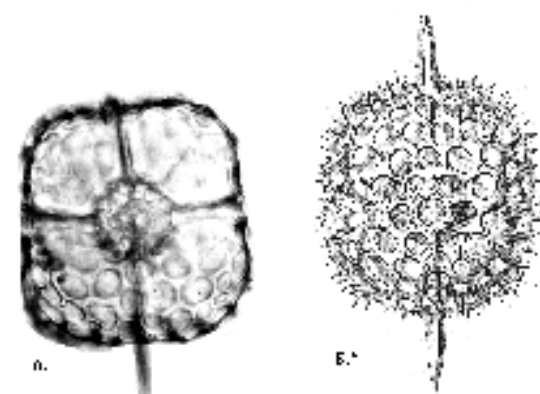

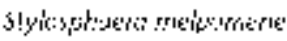

Figure 15.34.

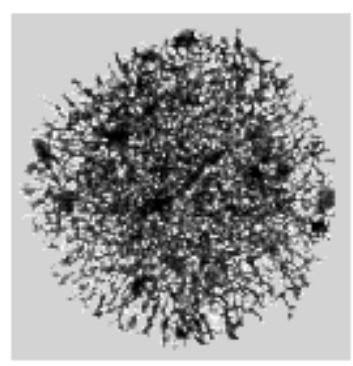

Styptosphaera symeriaced

Figure 15.50.

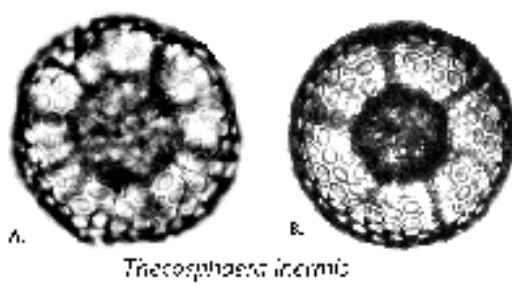

Figure 15.38.
Stylosphaera melpomene Haeckel (Figure 15.34) [=Stylacontarium bispiculum]. Two or three (?) latticed shells, outermost with characteristically sub-quadrangular outline, moderately thick-walled, thorny, with irregularly shaped pores; medullary shell spherical. Six stout beams join the two shells; usually two of these beams protrude outside as short, three-bladed polar spines, but the other two pairs may also extend slightly beyond the cortical shell-wall. Polar spines of equal or different size. Outermost shell diameter without spines: 80-130 $\mu \mathrm{m}$. Ref: Benson (1966).

Styptosphaera spumacea Haeckel (Figure 15.50). Shell is an irregular spongy mass without central cavity. Shell diameter: ca. $450 \mu \mathrm{m}$. Ref: Boltovskoy and Jankilevich (1985).
Thecosphaera inermis (Haeckel) (Figure 15.38). Three concentric latticed shells; pores on outermost relatively small, circular, regularly arranged, without frames (in some specimens frames around the pores can develop, in which case this species merges with Actinomma sol). Cortical shell usually smooth, barren of spines. Cortical shell diameter: ca. $80 \mu \mathrm{m}$. Ref: Boltovskoy and Riedel (1980). 


\section{Order Spumellaria}

\section{Family Coccodiscidae}

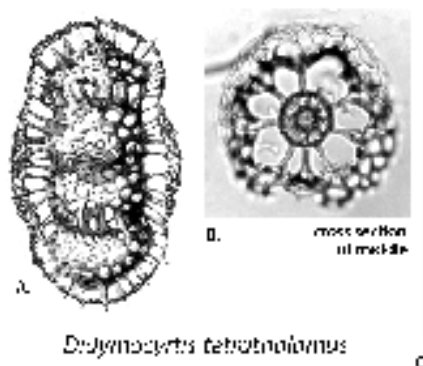

Figure 15.77.

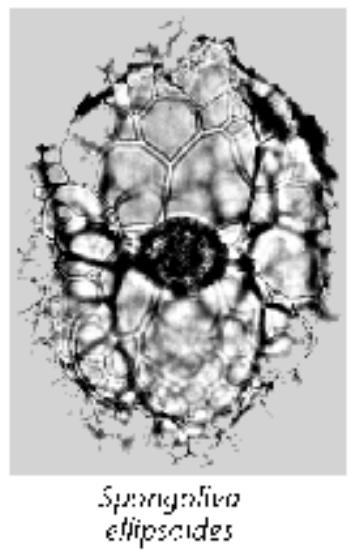

Figure 15.76.
Didymocyrtis tetrathalamus (Haeckel) (Figure 2J, 15.77) [=Ommatartus tetrathalamus, Panartus tetrathalamus]. Cortical shell cylindrical to ellipsoidal with a very conspicuous equatorial constriction. Two medullary shells (outermost slightly compressed, innermost spherical) joined to the cortical by several radial beams confined to the equatorial plane. May have polar caps (Figure 2J) or spines, and supplemental peripheric growth (mantle; Figure 15.77). Height of cortical shell: $100-150 \mu \mathrm{m}$; height of polar cap: $40-65 \mu \mathrm{m}$. Ref: Nigrini and Moore (1979).

Spongoliva ellipsoides Popofsky (Figure 15.76). Generally similar to $D$. tetrathalamus, except that cortical shell is a much looser and irregular meshwork. Fully grown specimens usually have a well developed mantle. Height of cortical shell: 100-250 $\mu \mathrm{m}$. Ref: Benson (1966). 


\section{Order Spumellaria}

\section{Family Phacodiscidae}

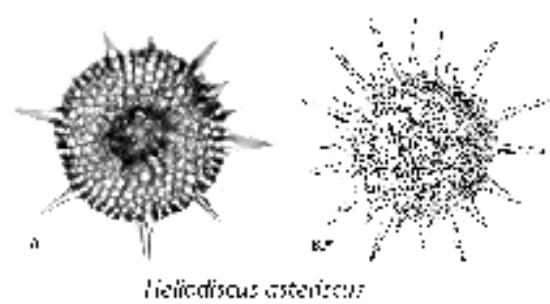

Figure 15.78.

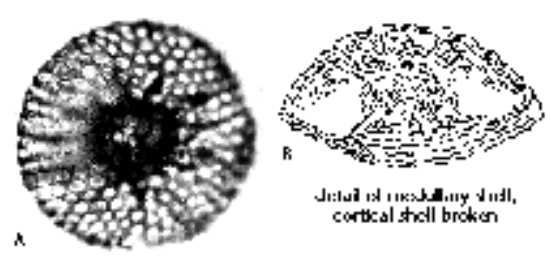

Sethodiscus macrococcus Haeckel (Figure 15.79).

Very similar to $H$. asteriscus, but without radial spines. Diameter of cortical shell: ca. $150 \mu \mathrm{m}$. Ref: Haeckel (1887), Boltovskoy and Riedel (1980).
Heliodiscus asteriscus Haeckel (Figure 15.78). Outer shell lenticular, with regularly arranged circular pores and ca. 8-15 radial spines on the equatorial plane; inner shell spherical. Diameter of cortical shell without spines: 120$200 \mu \mathrm{m}$. Ref: Nigrini and Moore (1979).

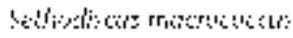

Figure 15.79. 


\section{Order Spumellaria}

\section{Family Spongodiscidae}

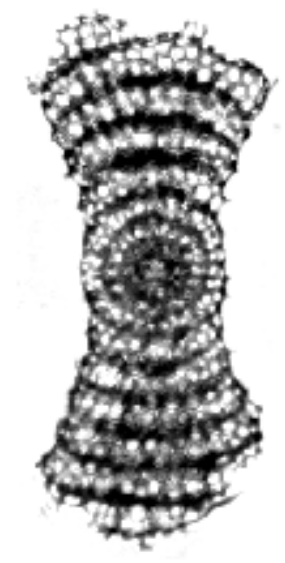

Arruphistiopolum ypsiton
Amphirhopalum ypsilon Haeckel (Figure 2R, 15.71, 15.75). Shell with two opposite chambered arms, one of them may be bifurcated distally, in which case the shell outline becomes trigonal. Total length: 200-300 $\mu \mathrm{m}$. Ref: Nigrini and Moore (1979).

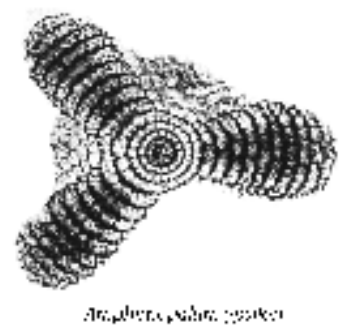

Figure 15.71 .

Figure 15.75 .

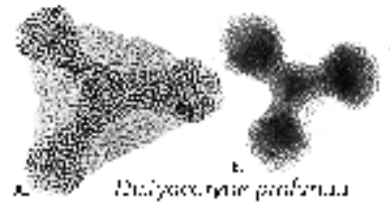

Figure 15.68.

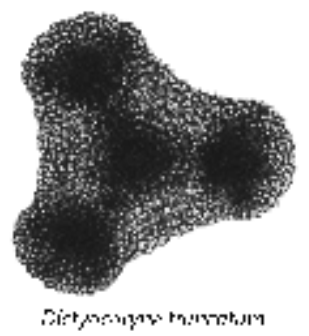

Figure 15.69.

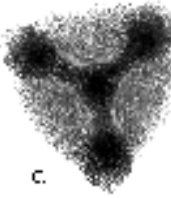

$150 \mu \mathrm{m}$. Ref: Nigrini and Moore (1979).

Dictyocoryne truncatum (Ehrenberg) (Figure 15.69). Very similar to $D$. profunda (and probably synonymous with it: intergrading specimens are very common); differs in having much broader arms and usually a well developed patagium (Figure 2Q, 2R). Length of arms (from center of shell): ca. $130 \mu \mathrm{m}$. Ref: Nigrini and Moore (1979). 


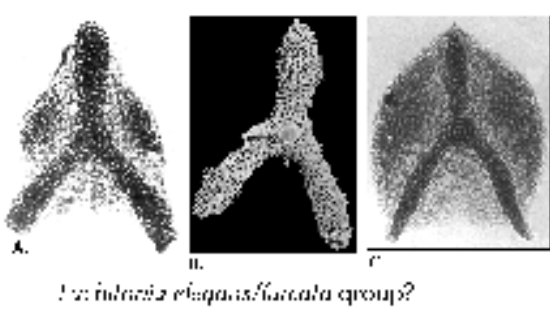

Figure 15.70.

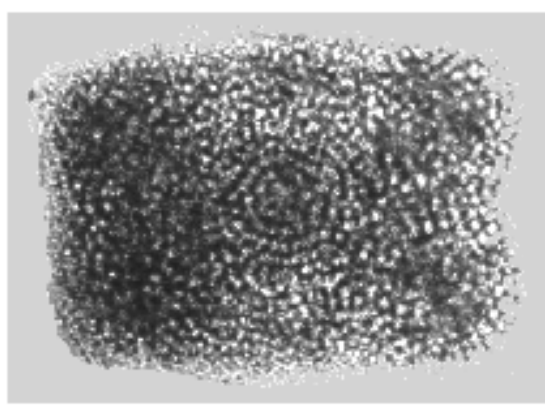

Sorigoster tetras uregutioris

Figure 15.66.

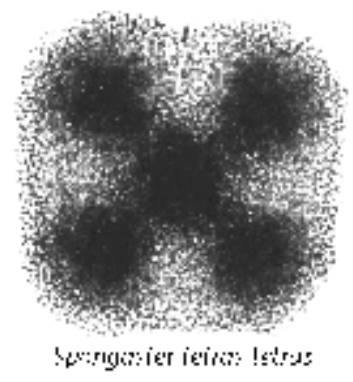

Figure 15.67.
Euchitonia elegans/furcata (Ehrenberg) group? (Figure 15.70) [=? Euchitonia furcata, Euchitonia elegans]. Differs from $D$. profunda in that the three arms are more slender, longer, and their orientation defines two larger angles and one smaller one. E. elegans intergrades smoothly with Euchitonia furcata; end members differ in that distal tips of arms taper in E. elegans (Figure 15.70c), while in $E$. furcata their terminations are club-shaped and more blunt (Figure 15.70a, b). Length of arms (from center of shell): 150-300 $\mu \mathrm{m}$. Ref: Nigrini and Moore (1979).

Spongaster tetras Ehrenberg irregularis Nigrini (Figure 15.66). Generally similar to $S$. tetras tetras, except that shell is less regular, angles between "arms" are uneven, and outline is an elongated rectange (rather than a square). Length of longer side: 140-260 $\mu \mathrm{m}$. Ref: Nigrini and Moore (1979).

Spongaster tetras tetras Ehrenberg (Figure 15.67). Shell outline rectangular with rounded corners; denser spongy meshwork defines four equidistant pear-shaped "arms" radiating from the center. Side of rectangle: 150$300 \mu \mathrm{m}$. Ref: Nigrini and Moore (1979). 


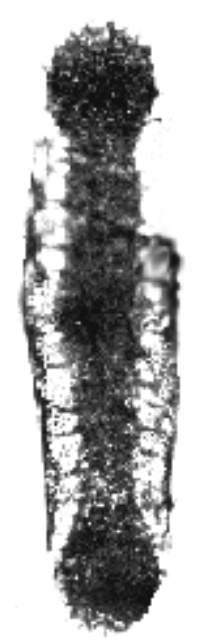

spongocore cylindrica

Figure 15.74.

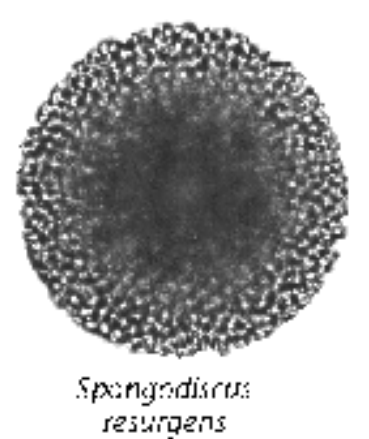

Figure 15.64.

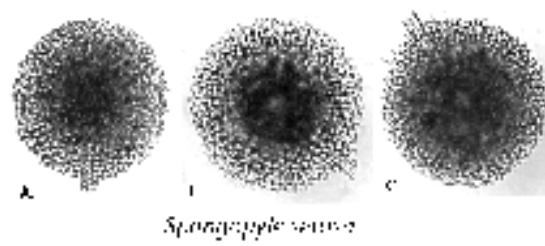

Figure 15.63.

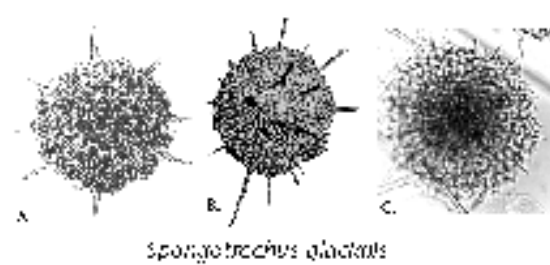

Figure 15.61.
Spongocore cylindrica Haeckel (Figure 15.74) [=Spongocore puella, Spongocore diplocylindrica]. Spongy cylinder with or without protruding spines and mantle, often with two slight constrictions. Total length: 200-360 $\mu \mathrm{m}$. Ref: Benson (1966).

Spongodiscus resurgens Ehrenberg (Figure 15.64). Spongy biconvex disc with no discernible structure, without spines on edges or surfaces of disc. Diameter of disc: 100-400 $\mu \mathrm{m}$. Ref: Boltovskoy and Riedel (1980).

Spongopyle setosa Dreyer (Figure 2N, 15.63) [=Spongopyle osculosa]. Similar to $S$. resurgens, except for the presence of a tubular, spiny or notched pylome on the margin. Diameter of disc: $100-300 \mu \mathrm{m}$. Ref: Riedel (1958).

Spongotrochus glacialis Popofsky (Figure 2I, 15.61). Similar to $S$. resurgens, except for the presence of spines on the surfaces and/or on the margins of the disc. Can have an inconspicuous pylome. Diameter of disc (without spines): 100-500 $\mu \mathrm{m}$. Ref: Riedel (1958), Petrushevskaya (1967). 


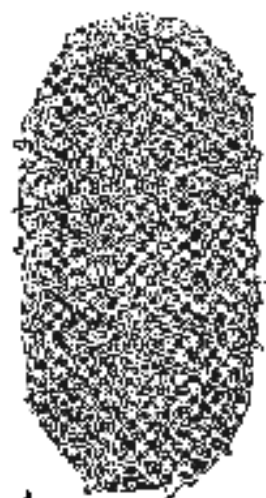

$\lambda$

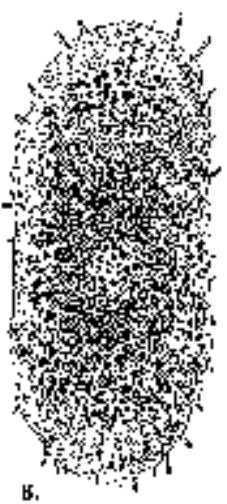

spongums pyionditious

Figure 15.72.

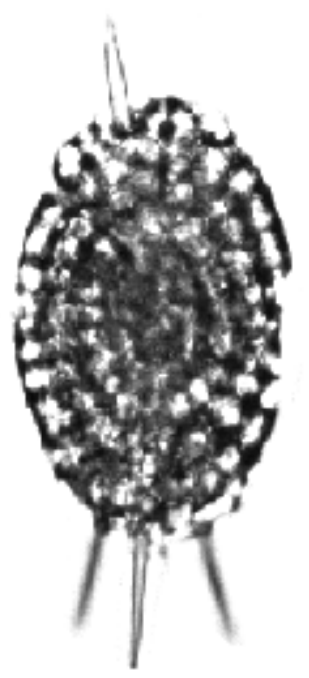

Spongurus

spp. group?

Figure 15.73.

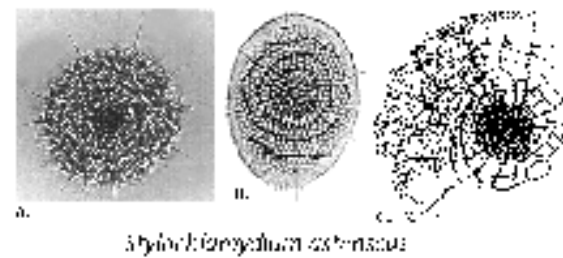

Figure 15.65.
Spongurus pylomaticus Riedel (Figure 15.72). Shell subcylindrical or elongate ellipsoidal, inner dense spongy meshwork surrounded by looser mantle, surface covered with bristle-like spines, with a pylome at one of the poles. Length: 70-250 $\mu \mathrm{m}$. Ref: Riedel (1958), Petrushevskaya (1967).

Spongurus spp. group? (Figure 15.73). Irregular, ovalelongate spongy mass, sometimes with concentric or spiral rings, with spines protruding at the poles. Length: ca. 100-150 $\mu \mathrm{m}$. Ref: Petrushevskaya (1967).
Stylochlamydium asteriscus Haeckel (Figure 2P, 15.65) [=? Stylochlamydium venustum]. Biconvex spongy disc more or less clearly partitioned into chambers by circular or spiral, continuous or broken, and radial bands. Both surfaces covered by a thin porous sieve plate which can extend beyond the central spongy mass. With or without protruding spines. Very similar morphotypes with an oval outline and a pylome have been cited under the name Stylochlamydium venustum Bailey (Figure 15.65b). 
Diameter of disc: $150-350 \mu \mathrm{m}$. Ref: Boltovskoy and Vrba (1988).

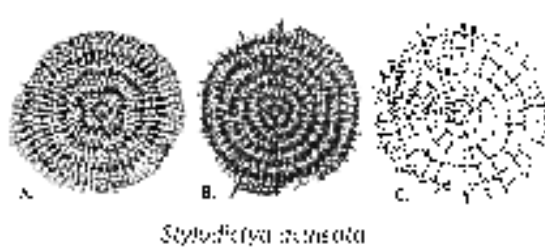

Figure 15.62.
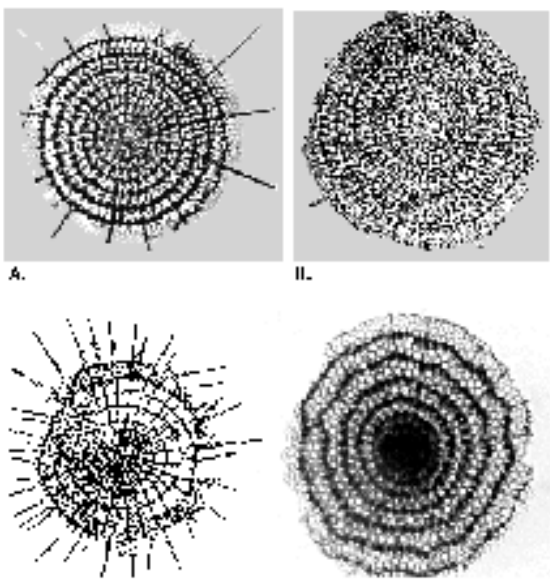

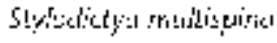

Figure 15.60.

Stylodictya aculeata Jorgensen (Figure 15.62). Flat disk not thickened in the center, with clearly defined circular concentric rings, the innermost rosette-shaped. Diameter of disc: ca. $150 \mu \mathrm{m}$. Ref: Petrushevskaya (1967), Boltovskoy and Vrba (1988).

Stylodictya multispina Haeckel (Figure 2O; 15.60) [=Stylodictya validispina, Stylodictya tenuispina]. Similar to $S$. aculeata, except that all rings are circular to subcircular (rather than rosette-shaped), center may be thickened (darker), and usually with marginal spines. Diameter of disc: 100-200 $\mu \mathrm{m}$. Ref: Boltovskoy and Vrba (1988). 


\section{Order Spumellaria}

\section{Family Litheliidae}
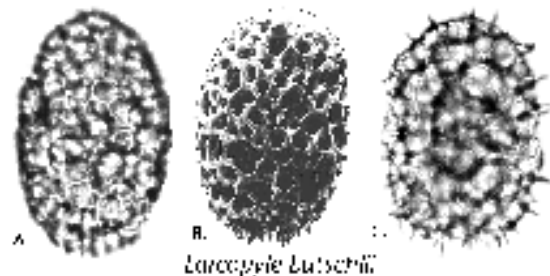

Larcopyle butschlii Dreyer (Figure 5B, 5B', 15.85).

Ellipsoidal outer shell with irregular pores, surface often thorny or spiny, inner structure spiral. One of the poles bears a pylome surrounded by larger spines. Major diameter: 80-170 $\mu \mathrm{m}$. Ref: Nigrini and Moore (1979).

Figure 15.85.
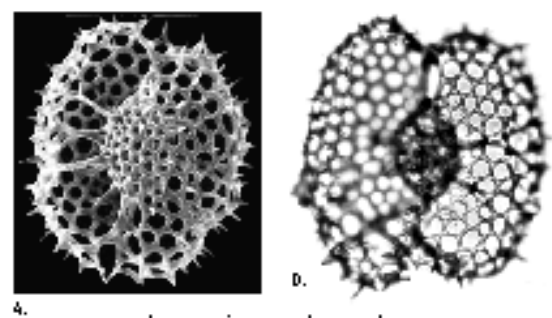

ג'

Figure 15.86.

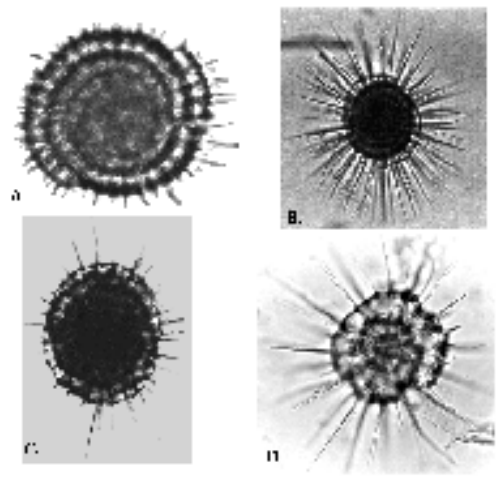

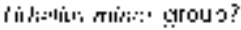

Figure 15.87.

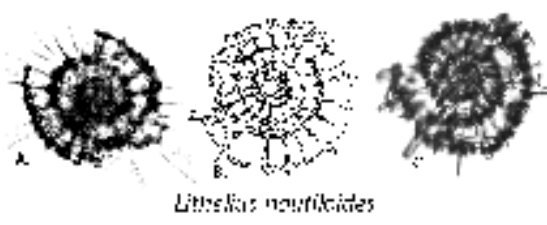

Figure 15.88.
Larcospira quadrangula Haeckel (Figure 15.86). Shell consists of two open spirals arising from a common origin. Breadth of shell: $120-250 \mu \mathrm{m}$. Ref: Nigrini and Moore (1979).
Lithelius minor Jorgensen group? (Figure 15.87).

Tightly wound spiral with thorny or spiny surface, outline circular or ovoid. Diameter: 80-150 $\mu \mathrm{m}$. Ref: Nigrini and Moore (1979).

Lithelius nautiloides Popofsky (Figure 5C, 5C', 15.88). Small, spherical medullary shell surrounded by an involute spiral of four-five whorls which increase in width outwards; surface spiny. Diameter: 100-230 $\mu \mathrm{m}$. Ref: Petrushevskaya (1967). 


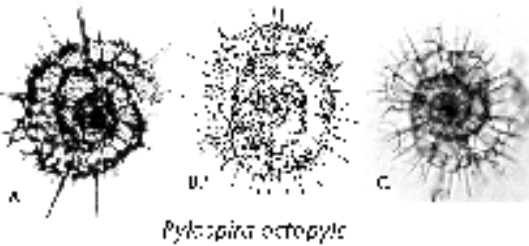

Figure 15.90.

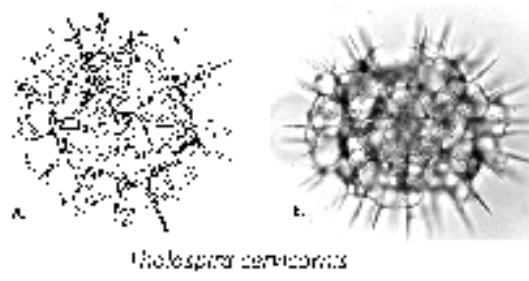

Figure 15.89.

Pylospira octopyle Haeckel (Figure 15.90) [=?Phorticium pylonium]. A series of spirally arranged chambers; outline ellipsoidal; surface spiny. Shell diameter: 80-130 $\mu \mathrm{m}$. Ref: Nigrini and Moore (1979).

Tholospira cervicornis Haeckel group (Figure 15.89). Irregular meshwork with pores of variable size; surface spiny. Probably an artificial category for lumping various juvenile, broken and poorly known Litheliidae and Pyloniidae. Ref: Petrushevskaya (1967), Takahashi and Honjo (1981). 


\section{Order Spumellaria}

\section{Family Pyloniidae}

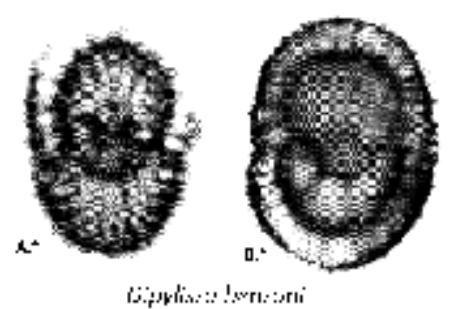

Figure 15.83.

Dipylissa bensoni Dumitrica (Figure 15.83). Shell fomed by three systems of globular caps, in optical section appearing as oval concentric subhemispheres interconnected by numerous thin radial beams. Major diameter: 90-120 um. Ref: Dumitrica (1988).

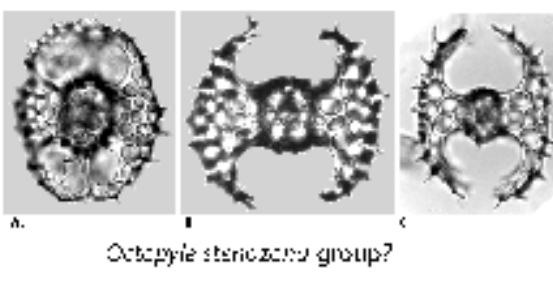

Figure 15.80 .

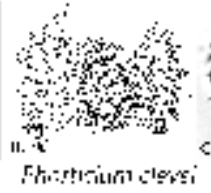

Figure 15.82.

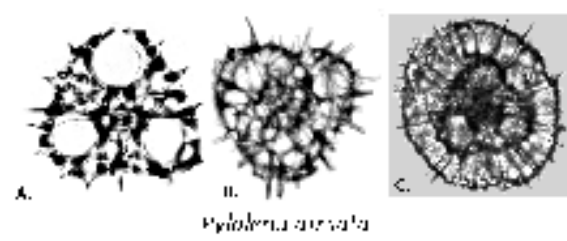

Figure 15.81.
Octopyle stenozona group? Haeckel (Figure 2L, 2M; 15.80) [=Tetrapyle octacantha]. Shells with two systems of latticed girdles (as described for the diagnosis of the family, see above) and large gates (Figure 2L, 2M). Major diameter: 100-250 $\mu \mathrm{m}$. Ref: Nigrini and Moore (1979).

Phorticium clevei (Jorgensen) (Figure 2L, 15.82) [=Phorticium pylonium]. Generally resembling $O$. stenozona, except that central part is a large structure formed by a series of spirally arranged chambers. Major axis of shell: 150-200 $\mu \mathrm{m}$. Ref: Petrushevskaya (1967).

Pylolena armata Haeckel group? (Figure 15.81) [=? Hexapyle spp.]. A central pyloniid shell surrounded by three centrifugally radiating girdles whose distal ends join forming a trigonal outline; this structure may be surrounded by supplementary growth in the form of a spherical latticed test. Diameter of fully developed shell: ca. $150 \mu \mathrm{m}$. Ref: Nigrini and Moore (1979). 


\section{Order Spumellaria}

\section{Family Tholoniidae}

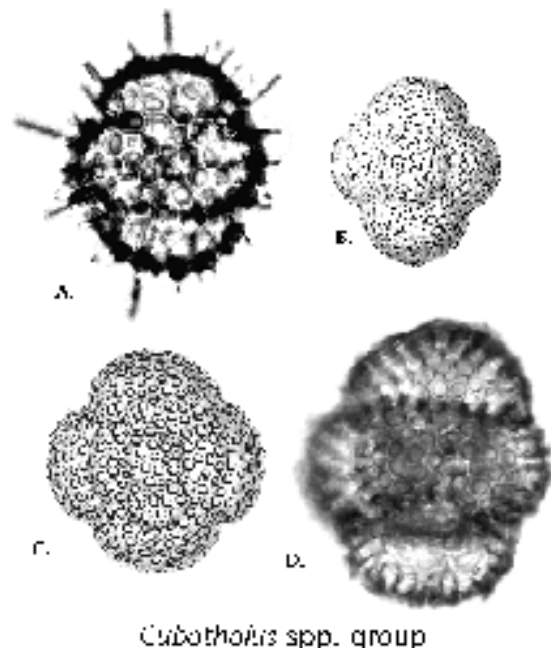

Cubotholus spp. (Figure 2K, 15.84) [=Tholonium spp., Amphitholus spp., Cubotholus cf. orthoceras]. Cortical shell composed of 6 hemispherical cupolas, opposite in pairs on the poles of three mutually perpendicular axes. Variously shaped "central chamber" with or without enclosed small medullary shell. Diameter: ca. $150 \mu \mathrm{m}$. Ref: Haeckel (1887).

Figure 15.84. 


\section{Order Nassellaria}

\section{Family Spyridae}

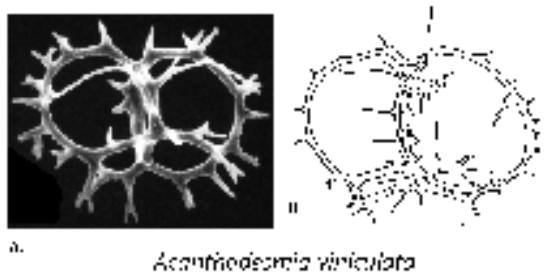

Acanthodesmia viniculata (Muller) (Figure 2C; 15.96) [=Giraffospyris angulata]. Shell composed of a D-shaped sagittal ring, a basal ring and a frontal ring (see Figure 3C). Breadth of frontal ring: ca. 140-180 $\mu \mathrm{m}$. Ref: Petrushevskaya (1971a), Nigrini and Moore (1979).

Figure 15.96.

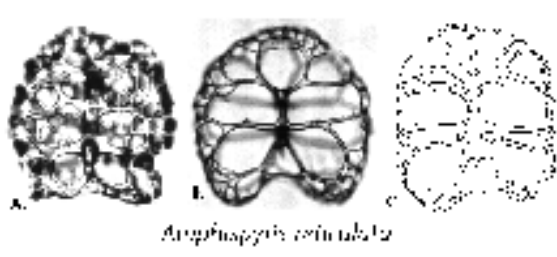

Figure 15.95.

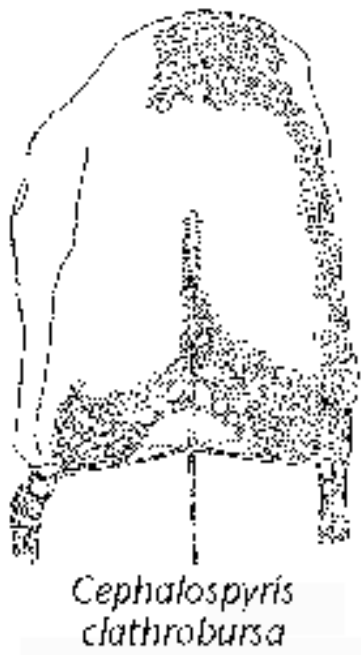

Figure 15.102.
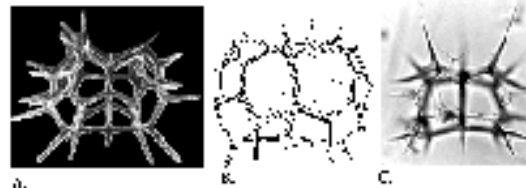

Figure 15.97.
Amphispyris reticulata (Ehrenberg) (Figure 15.95) [=Liriospyris reticulata, ?Tholospyris procera]. From the D-shaped sagittal ring 6 pairs of bars arise which branch and anastomose forming the latticed lateral walls of the shell. Breadth of shell: ca. $230 \mu \mathrm{m}$. Ref: Nigrini and Moore (1979).

Cephalospyris clathrobursa Haeckel (Figure 15.102). Sub-ovoid shell with very delicate, thin wall and very small pores; main lateral spines extend as three-bladed or hollow and perforated feet. Shell height: ca. $200 \mu \mathrm{m}$. Ref: Petrushevskaya (1971a).
Lophospyris pentagona pentagona (Ehrenberg) (Figure 15.97) [=Lophospyris quadriforis, Lophospyris pentagona]. Bars arising from sagittal, basal and frontal rings define large, very regular, polygonal pores. Skeletal bars and spines sharply three-bladed. Breadth of shell: ca $150 \mu \mathrm{m}$. Ref: Petrushevskaya (1971a). 


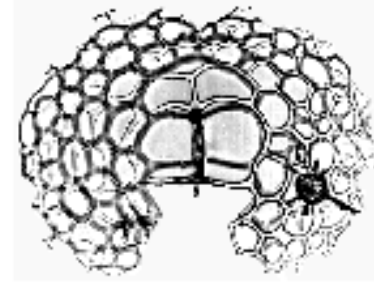

incrinin:

Figure 15.99.

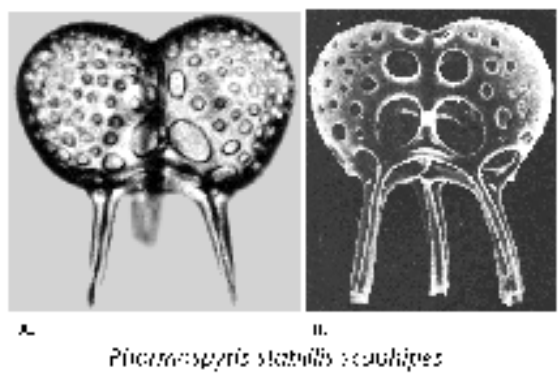

Figure 15.93.
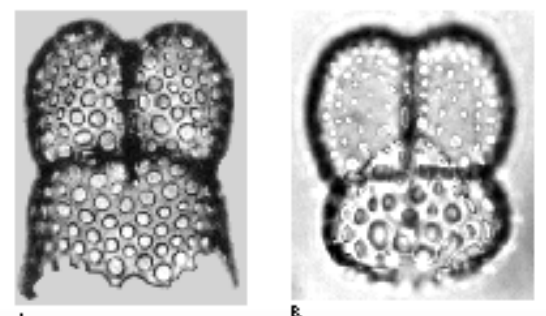

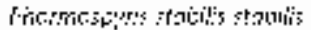

Figure 15.100.

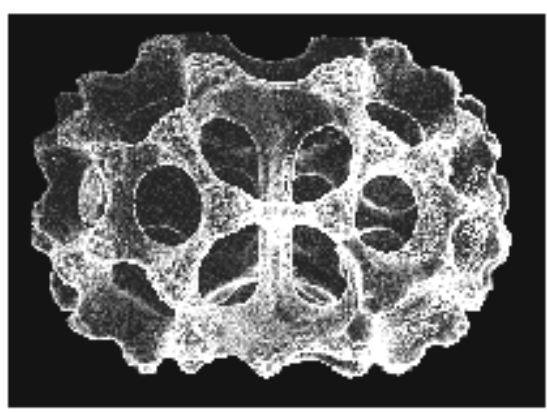

Tholospyris anthophora (Haeckel) (Figure 15.98). Oval-shaped sagitally constricted skeleton with very heavy bars and circular pores. Shell breadth: ca. $140 \mu \mathrm{m}$.

Ref: Goll (1969, 1972).

Nephrospyris renilla Haeckel (Figure 15.99) [=Nephrodictyum renilla]. The front and back of the sagittal ring produce branches that fork and anastomose distally; the two sets of lattice plates thus formed are not interconnected laterally. Breadth of shell: ca. $200 \mu \mathrm{m}$. Ref: Petrushevskaya (1971a), Goll (1972).

Phormospyris stabilis scaphipes (Haeckel) (Figure 15.93). Bi-lobulate, sagitally constricted, thin walled skeleton with three conspicuous feet protruding from basal ring. Breadth of shell: ca $80 \mu \mathrm{m}$. Ref: Goll (1976).

Phormospyris stabilis stabilis (Goll) (Figure 15.100). Cephalis thin-walled, bilobulate, separated by a conspicuous annular constriction from the conical thorax. Thorax open or closed. Both segmens with regular, circular pores. Breadth of shell: ca $110 \mu \mathrm{m}$. Ref: Goll (1976).

Thotospyris anthophora

Figure 15.98. 


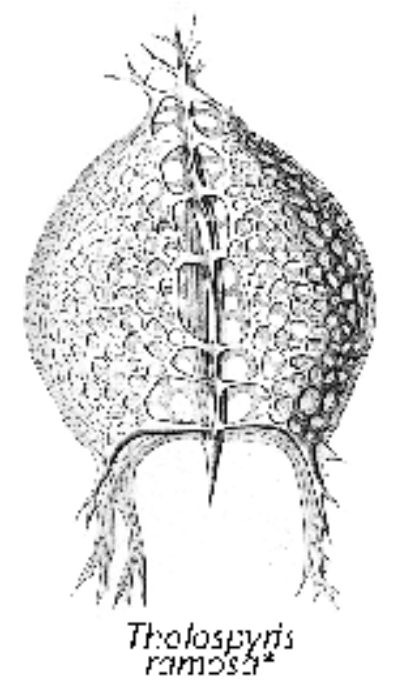

Figure 15.91.*
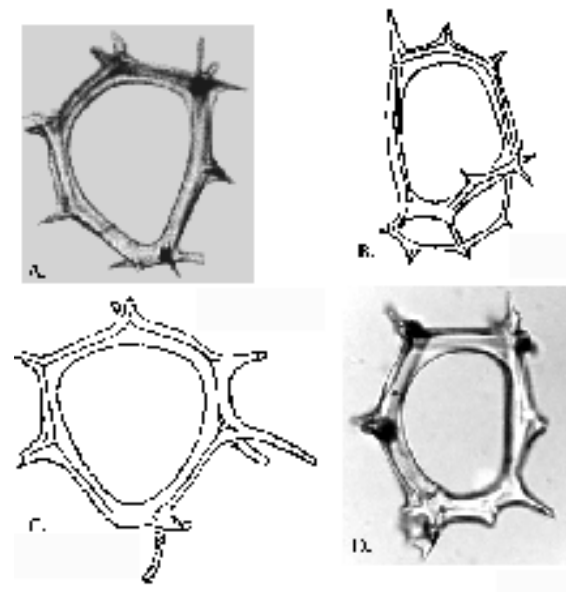

Ihoivsoyins spp. givulp

Figre 15.103.

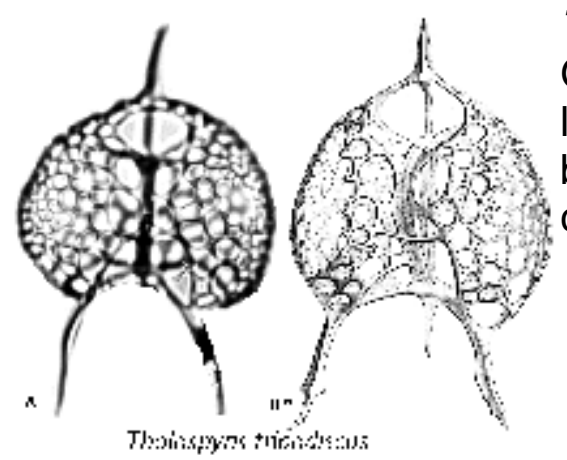

Figure 15.92.
Tholospyris ramosa (Haeckel) (Figure 15.91) [=Androspyris ramosa]. Shell pear-shaped, sagitally constricted, with a well-developed galea and three feet whose distal ends can be spatulated or forked. Shell height: ca. 180 m. Ref: Takahashi (1991).
Tholospyris spp. group (Figure 15.103). Rings of variable size and form very common in most warm water materials; most of these are probably juvenile representatives of various Spyridae.
Tholospyris tripodiscus Haeckel (Figure 15.92).

Generally similar to $T$. ramosa, but with conspicuously larger pores on both sides of the sagittal ring and at the base of the galea; feet usually unbranched. Shell height: ca. $150 \mu \mathrm{m}$. Ref: Petrushevskaya (1971a). 


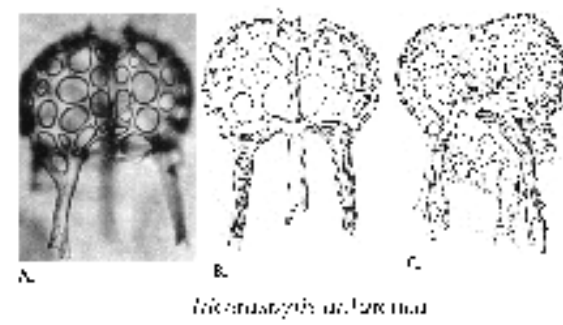

Figure 15.94 .

Triceraspyris antarctica (Haecker) (Figure 15.94) [= Triospyris antarctica, Phormospyris stabilis antarctica]. Heavy bilobulated cephalis with irregularly distributed circular pores and three massive, simple or branched feet at the base; rudiments of thoracic lattice often present between feet. Shell breadth: ca. $100 \mu \mathrm{m}$. Ref: Petrushevskaya (1967).

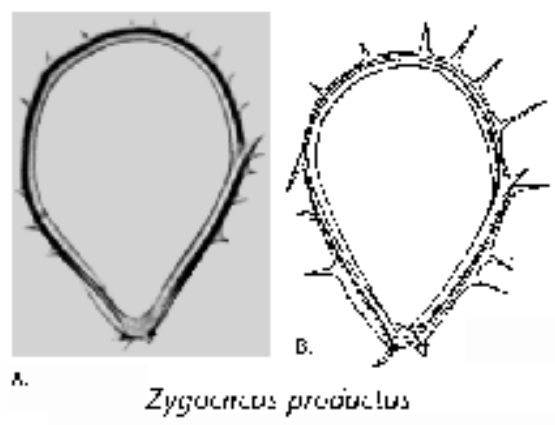

Zygocircus productus (Hertwig) (Figure 15.101). Pearshaped or D-shaped, spiny, three-bladed sagittal ring. Major diameter: 90-140 $\mu \mathrm{m}$. Ref: Petrushevskaya

Figure 15.101. 


\section{Order Nassellaria}

\section{Family Plagoniidae}

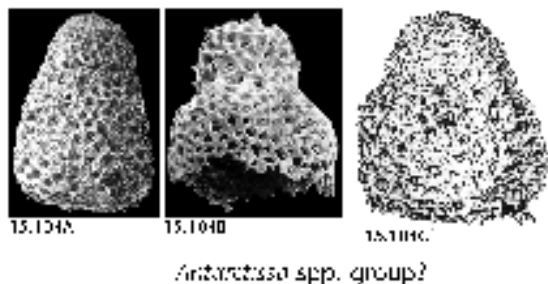

Figure $15.104 \mathrm{C}$.

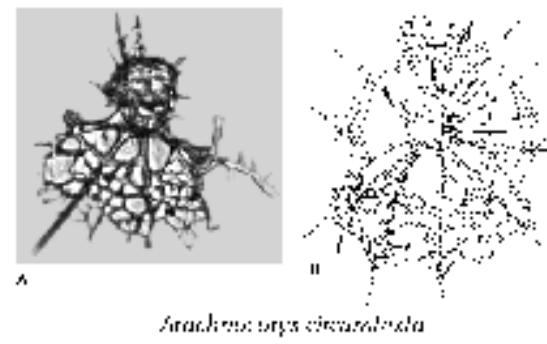

Figure 15.110.

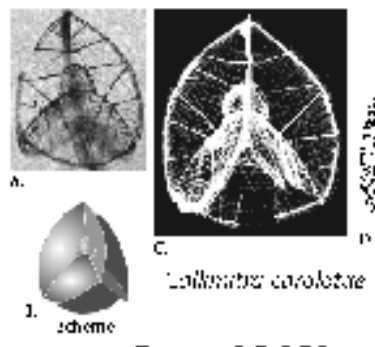

Figure 15.123.

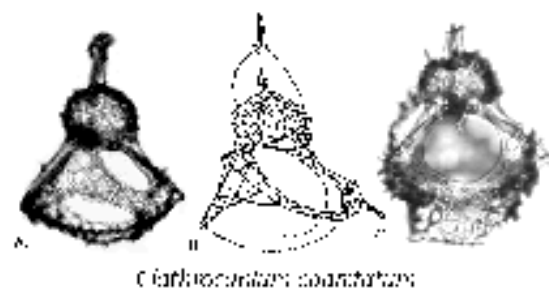

Figure 15.114.
Antarctissa spp. group? (Figure 3D, 15.104) [=?Antarctissa strelkovi, ?Antarctissa longa]. Shell outline triangular to oval, cephalis partly submerged into thorax. Shell-wall thick. A. strelkovi (Figure 3D) and A. longa differ from $A$. denticulata by having thinner and spinier shell-walls. Shell height: 100-160 $\mu \mathrm{m}$. Ref: Petrushevskaya (1967).

Arachnocorys circumtexta Haeckel (Figure 15.110). Spherical cephalis provided with numerous spines; those directed upwards are interconnected by a spider web-like lattice of very thin bars; the ones directed toward the base support an incipient thorax formed by a coarser lattice with irregular pores, with several very large pores located in the neck area. Overall shell height: ca. 140 $\mu \mathrm{m}$. Ref: Petrushevskaya (1971a).

Callimitra carolotae Haeckel (Figure 15.123). The small, dome-shaped cephalis is provided with very long apical (directed upwards), dorsal and main lateral spines (directed down and sideways) interconnected by a delicate meshwork which forms three basal plates and three lateral plates. Overall shell height: ca. $200 \mu \mathrm{m}$. Ref: Haeckel (1887).

Clathrocanium coarctatum Ehrenberg (Figure 15.114). Cephalis with a large, three-bladed apical horn which may have lateral thread-like, anastomosing pojections. The dorsal and two main lateral spines, directed down and sideways, are joined by narrow lattice plates which form a small thorax. Overall shell height: ca. $100 \mu \mathrm{m}$. Ref: Petrushevskaya (1971a). 


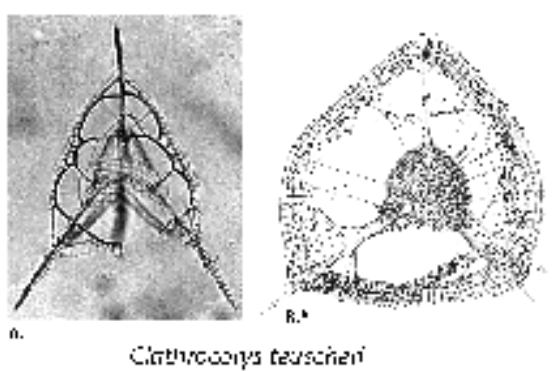

Figure 15.112.
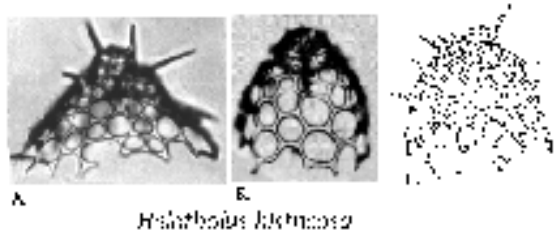

Figure 15.113.
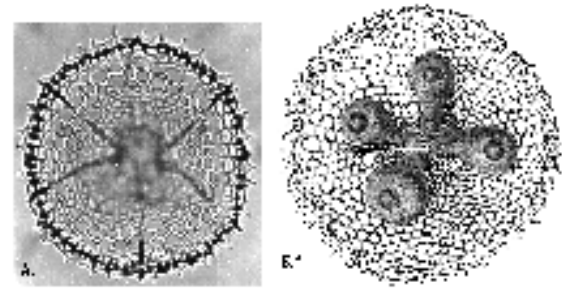

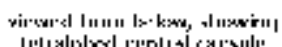

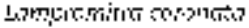

Figure 15.115.

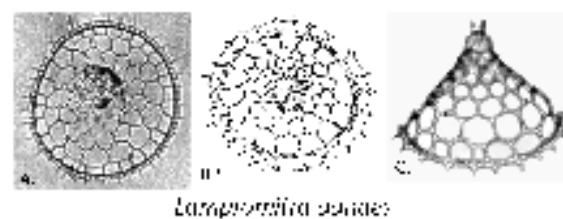

Figure 15.116.

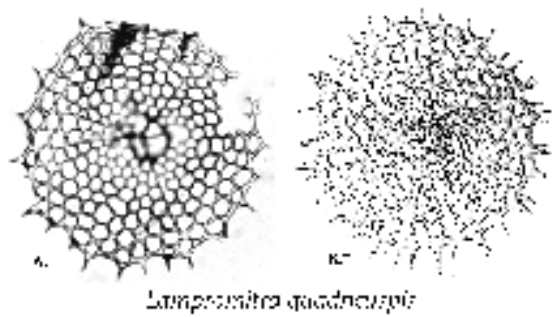

Figure 15.117.
Clathrocorys teuscheri Haeckel (Figure 2G; 15.112). Similar to $C$. coaerctatum, except that the apical, dorsal and main lateral spines are joined by a well-developed lattice. Overall shell height: ca. 150-190 $\mu \mathrm{m}$. Ref:

Petrushevskaya (1971a).

Helotholus histricosa Jorgensen (Figure 15.113). Spiny, dome-shaped shell. Cephalis merging smoothly with thorax; thorax with large and irregular pores, without defined termination. Maximum shell width: ca. 100-120 $\mu \mathrm{m}$. Ref: Petrushevskaya (1971a).

Lampromitra coronata Haeckel (Figure 15.115). Shell in the shape of a Chinese peasant hat. Thorax with subregular circular pores increasing in size slightly towards the base, with a well defined peristome of a row of small pores and minute spines. Shell diameter: ca. 200 $\mu \mathrm{m}$. Ref: Petrushevskaya (1971a).

Lampromitra danaes (Haeckel) (Figure 15.116) [=Corocalyptra danaes]. Overall shell-shape similar to $L$. coronata. Pores on thorax regular, polygonal, strongly increasing in size toward its base. Rim of thorax represented by a very regular row of small, rectangular pores followed inmmediately by one of much larger pores. Shell diameter: ca. 180 um. Ref: Haeckel (1887), as Clathrocyclas danaes.

Lampromitra quadricuspis Haeckel (Figure 15.117). Generally similar to $L$. coronata, except that cephalis is more elongate, pores on thorax are larger and its termination is ragged. Shell diameter: $120-350 \mu \mathrm{m}$. Ref: Benson (1966). 


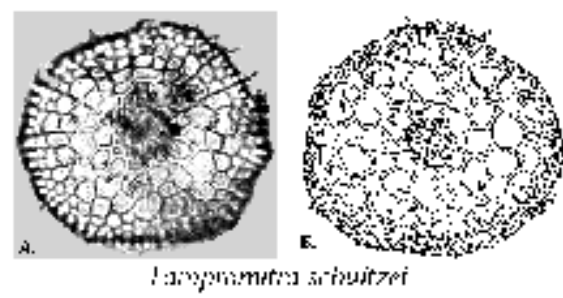

Figure 15.118.

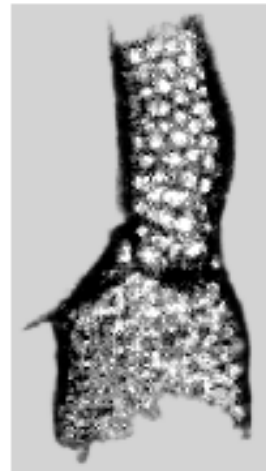

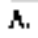
Lophophoency Lutschlij

Figure 15.108.

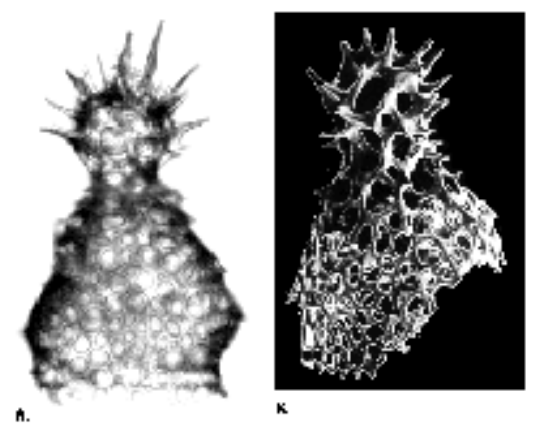

Lophophaena hispida (Ehrenberg) (Figure 3I; 15.109). Cephalis spherical, with very large pores and many long, thin spines. Thorax conical, its pores decreasing in size toward the base; sometimes an incipient abdomen present. Overall shell height: ca. $150 \mu \mathrm{m}$. Ref: Petrushevskaya (1971a).
Lampromitra schultzei (Haeckel) (Figure 15.118). Similar to $L$. coronata, except that pores on thorax are considerably larger and less regular. Peristome with twothree rows of regularly aligned, small, subrectangular pores. Shell diameter: ca. $100 \mu \mathrm{m}$. Ref: Boltovskoy and Riedel (1980).

Lophophaena butschlii (Haeckel) (Figure 15.108). Elongated cephalis, the top of which is usually unfinished, short conical thorax. Overall shell height: ca. $100 \mu \mathrm{m}$. Ref: Petrushevskaya (1971a).

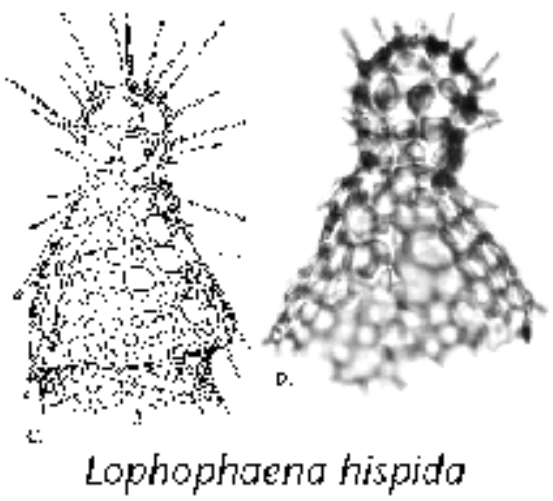

Figure 15.109. 


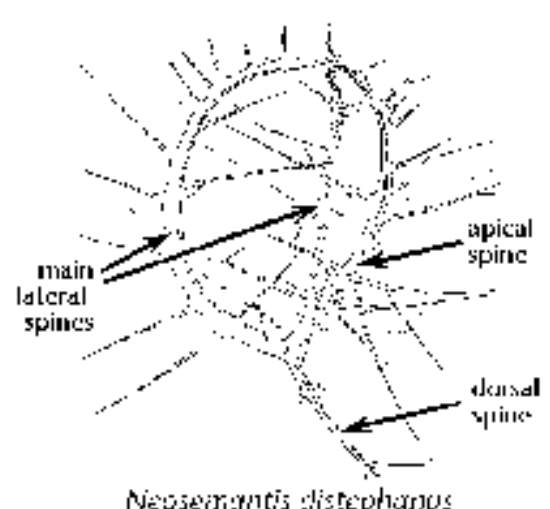

Figure 15.120.

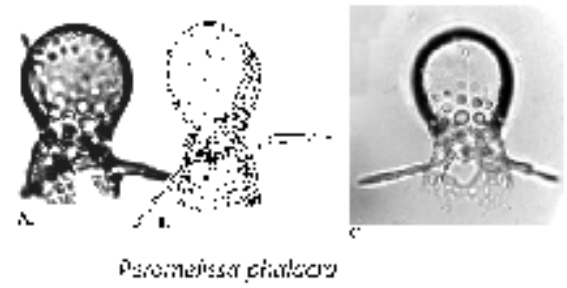

Figure 15.107.

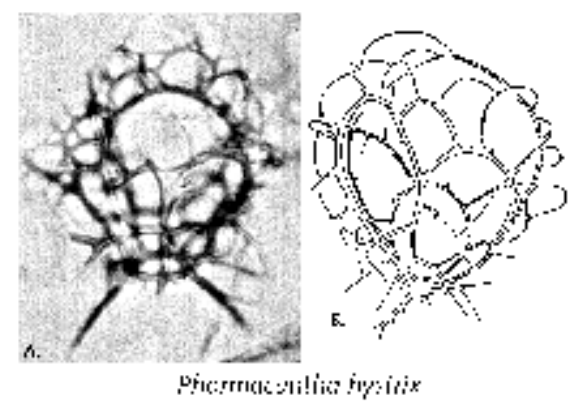

Figure 15.111.

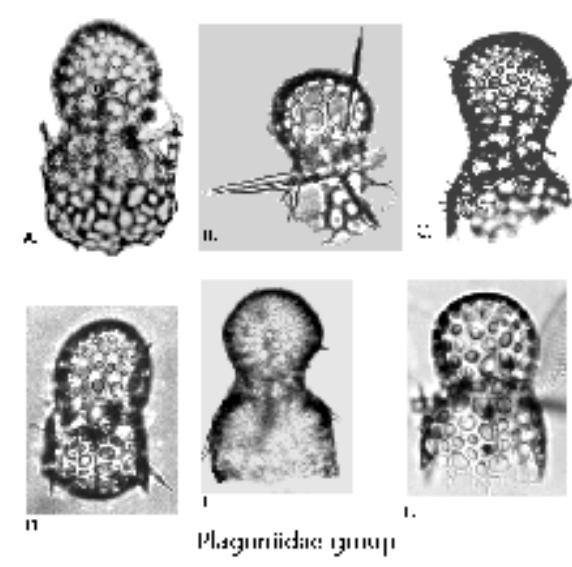

Plagoniidae group (Figure 15.105). Includes many generally similar forms with a latticed cephalis and with or without a rudimentary thorax. The systematics of these sometimes extremely abundant forms is confused, and they are generally ignored in most surveys. They include species cited under a variety of generic names, such as Amphiplecta, Arachnocorallium, Arachnocorys, Ceratocyrtis, Dimelissa, Lophophaena, Lophophaenoma, Micromelissa, Peromelissa, Psilomelissa, etc.

Figure 15.105. 


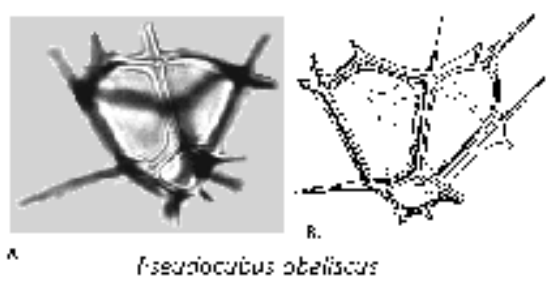

Figure 15.122.

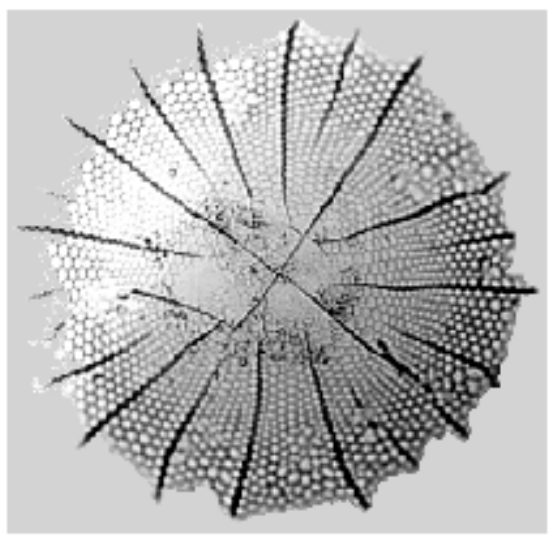

Setrioptiormis auratio

Figure 15.121.

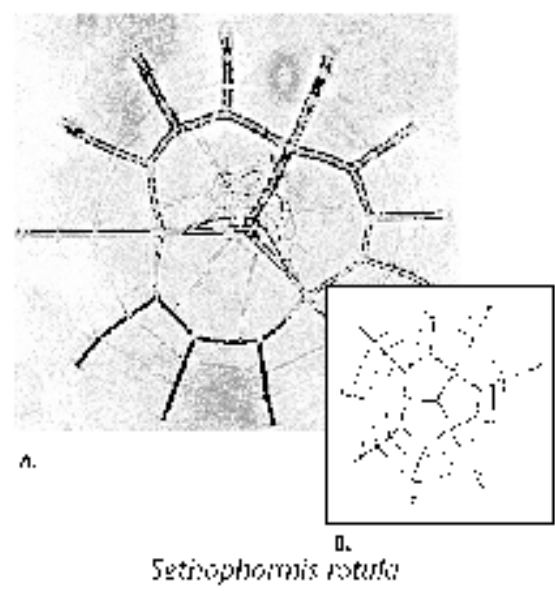

Figure 15.124.
Pseudocubus obeliscus Haeckel (Figure 15.122). Skeleton represented by the sharply three-bladed edges of a 4-sided, truncated pyramid. Shell height: ca. $40 \mu \mathrm{m}$. Ref: Petrushevskaya (1971a).

Sethophormis aurelia Haeckel (Figure 3F; 15.121). Shell in the form of a Chinese peasant hat; cephalis cupola-shaped; thorax with a very delicate, lace-like meshwork of irregular pores decreasing in size toward the periphery and many radial sinuous ribs. Shell diameter: 150-200 $\mu \mathrm{m}$. Ref: Petrushevskaya (1971a).

Sethophormis rotula (Haeckel) (Figure 15.124). Central part of spider web-like skeleton is an hexagonal ring whose vertices support 6 radiating spines; three additional radial spines (dorsal and two main lateral) merge in center of hexagon. All spines produce rather regularly spaced anastomosing lateral branches. Diameter of central hexagon: ca. $40 \mu \mathrm{m}$. Ref: Petrushevskaya (1971a). 


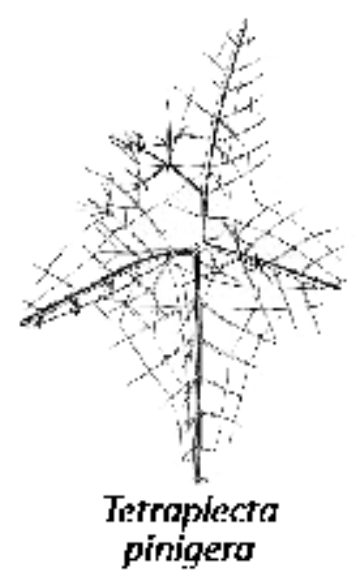

Figure 15.119.

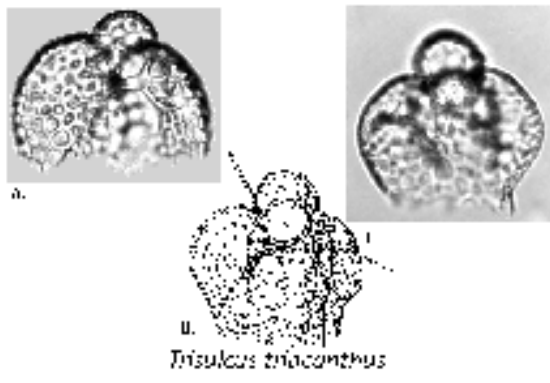

Figure 15.106.
Tetraplecta pinigera Haeckel (Figure 15.119). Skeleton reduced to four equidistant three-bladed spines arising from a common central point; spines produce thin lateral braches which can anastomose forming a delicate, irregular web. Length of each spine: 25-30 $\mu \mathrm{m}$. Ref: Haeckel (1887).

Trisulcus triacanthus Popofsky (Figure 15.106). Small, sparsely perforated cephalis sitting on top of a conspicuously three-lobulated thorax, lobes are most evident in the uppermost part, disappearing gradually toward the base. Shell height: ca. $60 \mu \mathrm{m}$. Ref:

Petrushevskaya (1971a). 


\section{Order Nassellaria}

\section{Family Theoperidae}

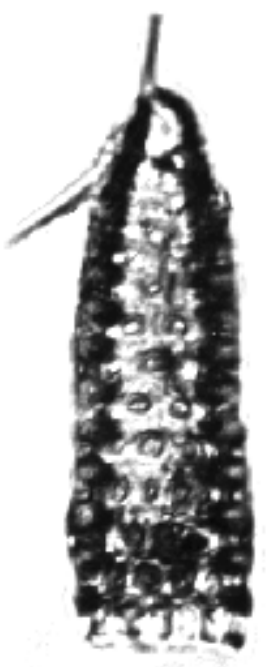

A.

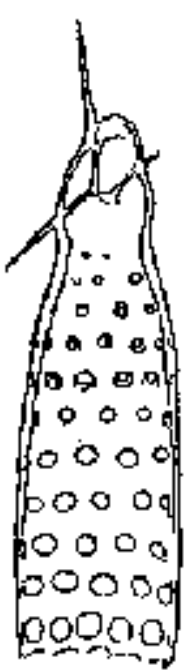

I.
Artostrobus annulatus

Figure 15.125.

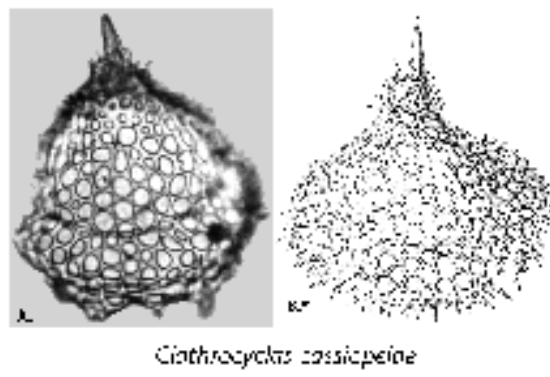

Clathrocyclas cassiopeiae Haeckel (Figure 15.126). Small cephalis with a stout apical horn and many smaller spines. Thorax large, campanulate, with irregular pores. Abdomen short, truncated, with ragged, spiny termination. Shell height: 100-200 $\mu \mathrm{m}$. Ref: Haeckel (1887).
Artostrobus annulatus (Bailey) (Figure 15.125).

Cephalis cup-shaped, poreless, with a thin apical horn.

Thorax cylindrical, with circular (proximally) to subrectangular (distally) pores in transverse rows, increasing in size toward the base. Shell height: up to $160 \mu \mathrm{m}$. Ref: Riedel (1958), Petrushevskaya (1967).

Figure 15.126. 

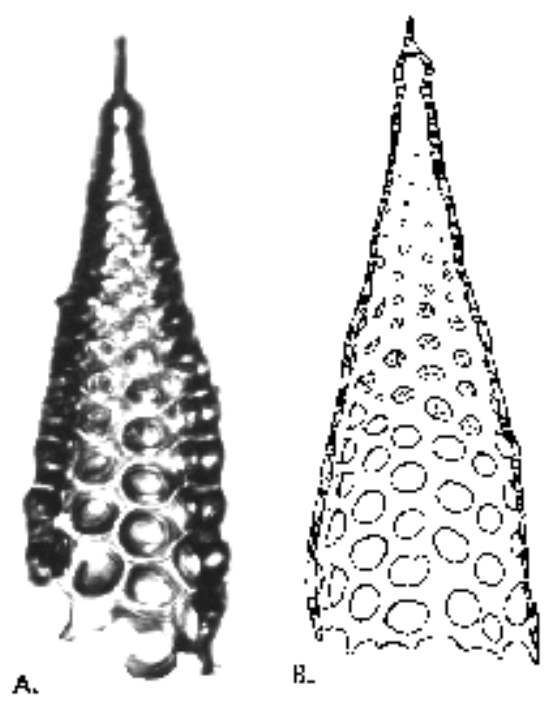

B.

Comutella profunda

Figure 15.127.

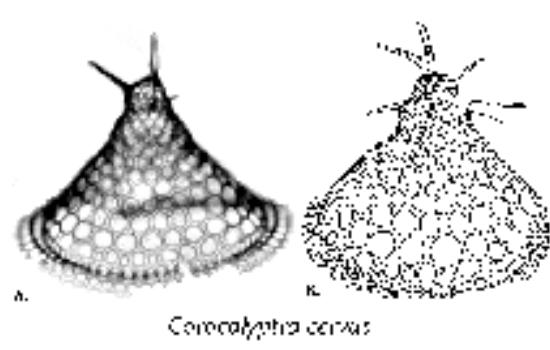

Corocalyptra cervus (Ehrenberg) (Figure 15.128). Cephalis with a large apical horn, often forked distally. Thorax large, campanulate, with regular, polygonal pores in transversal rows increasing in size distally. Abdomen restricted to a narrow brim with several rows of small pores. Shell height: 100-200 $\mu \mathrm{m}$. Ref: Benson (1966).
Cornutella profunda Ehrenberg (Figure 15.127). Narrow, bilocular conical shell with very small subspherical poreless cephalis with or without apical horn. Pores on thorax circular, increasing in size toward the base. Sell height: 120-230 $\mu \mathrm{m}$. Ref: Riedel (1958), Nigrini (1967).

Figure 15.128.

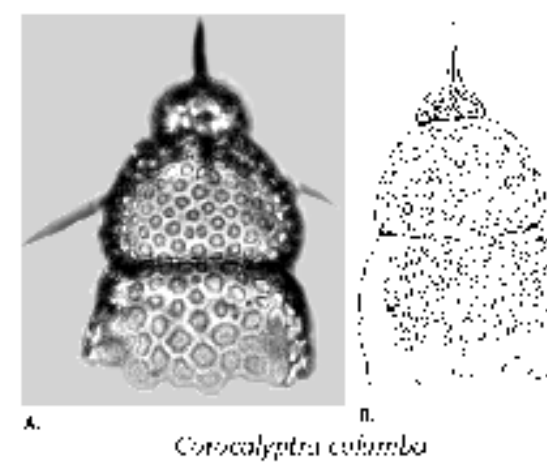

Figure 15.132. 


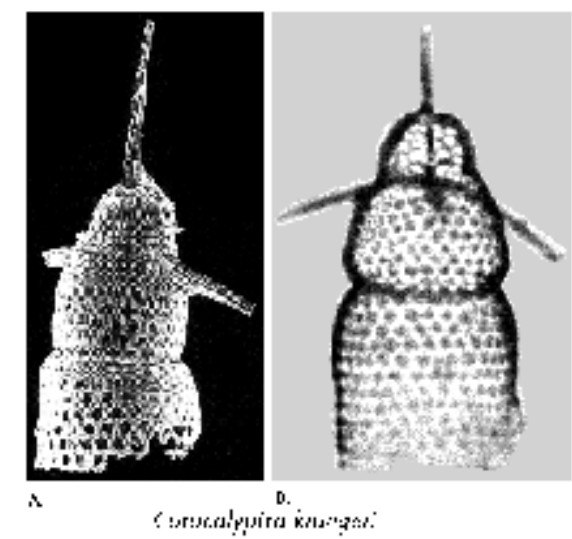

Figure 15.136.

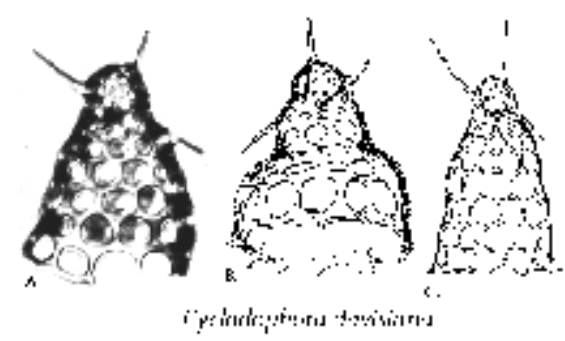

Figure 15.131.
Corocalyptra kruegeri Popofsky (Figure 15.136). Generally similar to $C$. columba; cephalis larger, thorax and abdomen cylindrical. Shell height: ca. $80 \mu \mathrm{m}$. Ref: Popofsky (1913).

Cycladophora davisiana (Ehrenberg) (Figure 15.131) [= Theocalyptra davisiana, ?Artostrobus jorgenseni]. Shell conical to campanulate. Cephalis subspherical, sparsely perforated, usually with two spines. Thorax conical to cylindrical, with circular (proximally) to quadrate (distally) pores increasing in size toward the base. Abdomen, when present, flared out, wider than thorax, with quadrate pores. Petrushevskaya (1967) described three subspecies of this form, of which $C$. davisiana (Ehrenberg) davisiana Petrushevskaya (Figure 15.131b) and C. davisiana (Ehr.) cornutoides (Petrushevskaya) (Figure 15.131c) are often used in current literature (the last one is probably synonymous with Artostrobus jorgenseni). Shell height: ca. $100 \mu \mathrm{m}$. Ref: Riedel (1958), Petrushevskaya (1967), Bjørklund and Ciesielski (1994). 


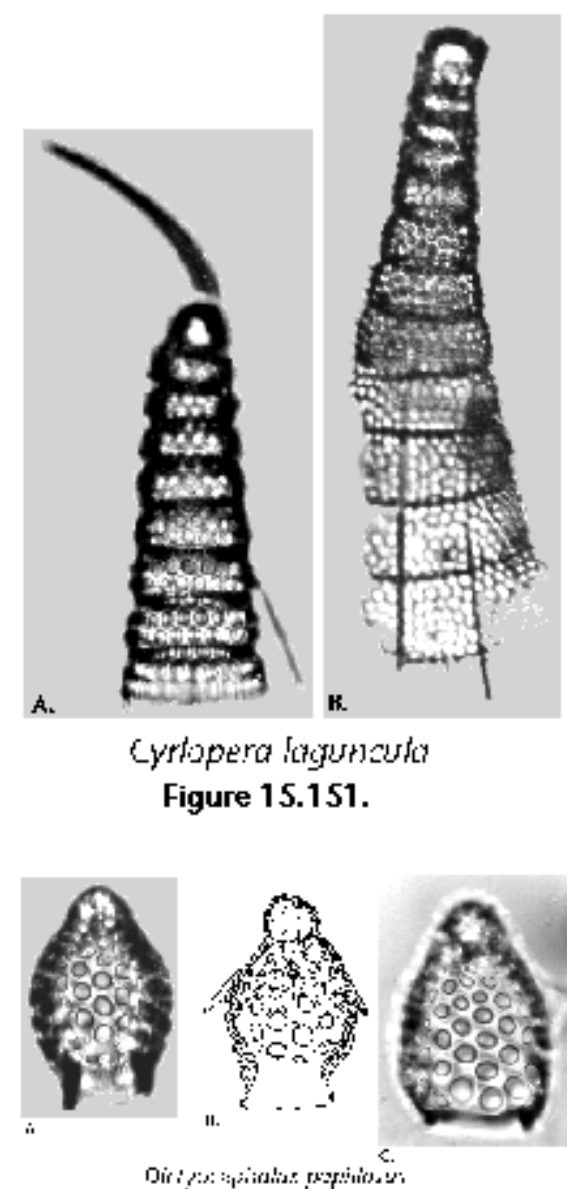

Figure 15.135.

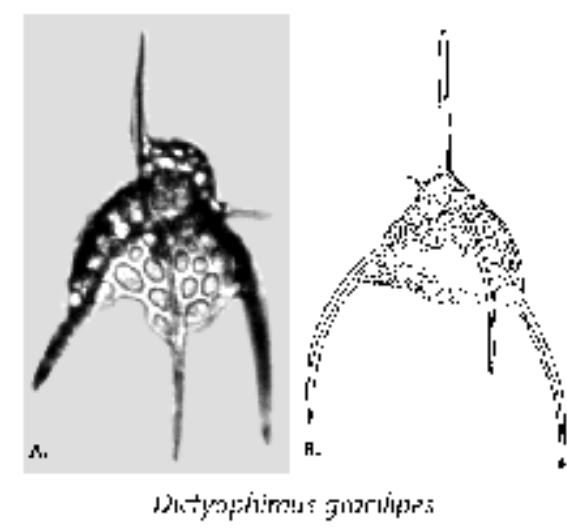

Figure 15.142.
Cyrtopera laguncula Haeckel (Figure 30; 15.151) [=Cyrtolagena laguncula, Stichopera pectinata]. Very typical multisegmented shell with conical outline and clearly marked constrictions; last segment may be open or closed. Shell height: 150-250 $\mu \mathrm{m}$. Ref:

Petrushevskaya (1971a).

Dictyocephalus papillosus (Ehrenberg) (Figure 15.135) [=Carpocanarium papillosum]. Two-segmented, thickwalled shell. Cephalis spherical. Thorax oval, with circular, usually framed pores, with three short wings, ending in a narrowed, poreless peristome. Shell height: 70-90 $\mu \mathrm{m}$. Ref: Petrushevskaya (1967).

Dictyophimus gracilipes Bailey (Figure 15.142) [=Pseudodictyophimus gracilipes, Dictyophimus clevei]. Cephalis partly submerged into thorax, bears a large apical horn. Thorax pyramidal or conical, mouth open or closed, with three conspicuous legs (dorsal and lateral spines). Shell height (without feet): 55-90 $\mu \mathrm{m}$. Ref: Petrushevskaya (1971a). 


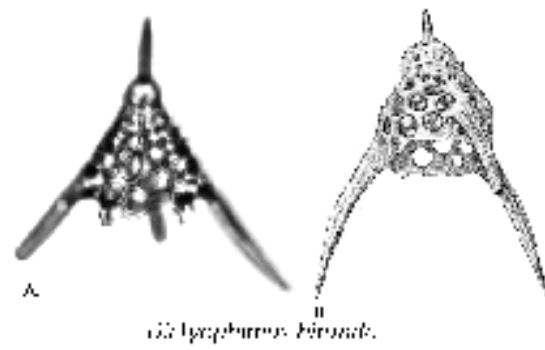

Figure 15.140.

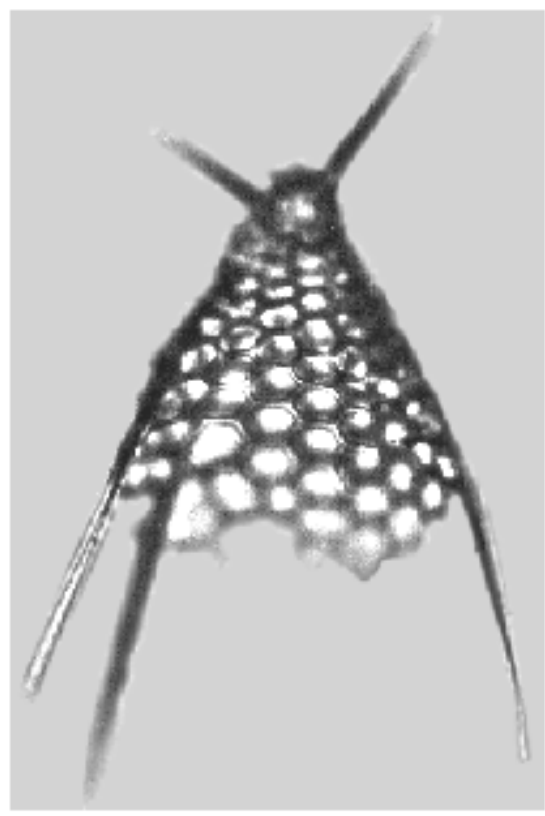

Dictyophimus

infovicatus

Figure 15.143.

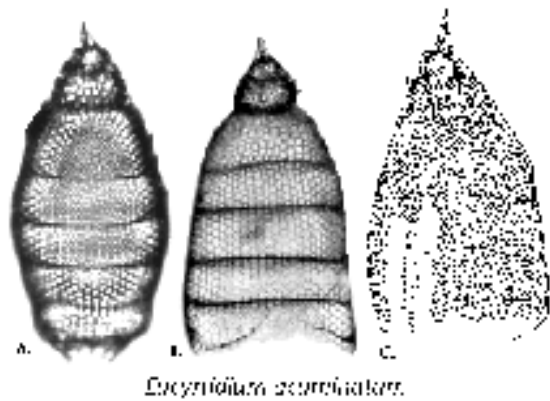

Figure 15.137.
Dictyophimus hirundo (Haeckel) (Figure 15.140) [=Pterocorys hirundo]. Cephalis, globular, sometimes spiny, with a stout, three-bladed apical horn. Thorax truncate-conical to campanulate, spiny, with large circular pores and three ribs which extend into massive, divergent feet. Highly variable species (species group?). Shell height (without feet): 50-100 $\mu \mathrm{m}$. Riedel (1958), Nigrini and Moore (1979).

Dictyophimus infabricatus Nigrini (Figure 3Q; 15.143). Similar to $D$. hirundo, but shell is thinner and pores are larger; cephalis usually wih two horns (apical and vertical spines), feet are smaller. Shell height (without feet): 90$200 \mu \mathrm{m}$. Ref: Nigrini and Moore (1979). 


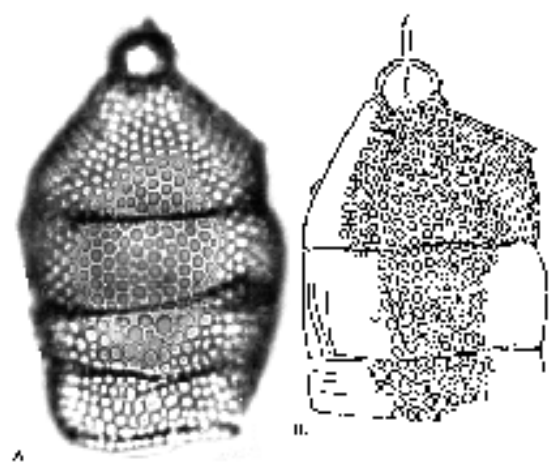

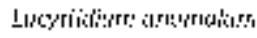

Figure 15.138.
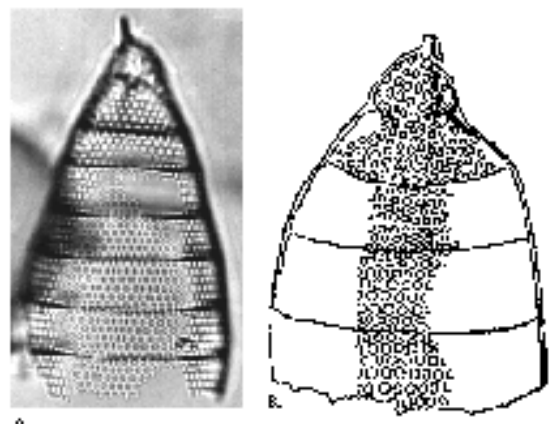

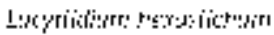

Figure 15.139.

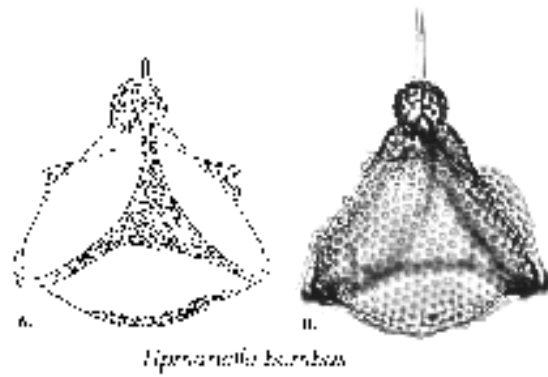

Lipmanella bombus (Haeckel) (Figure 15.133) [=Dictyoceras cf. pyramidale]. Very characteristic thorax where the dorsal and main lateral spines, which project down and sideways, are surmounted by latticed keels; these keels define the three slightly concave sides of the pyramidal thorax. Maximum shell width: 80-150 $\mu \mathrm{m}$. Ref: Benson (1966), Petrushevskaya (1971a).

Figure 15.133.

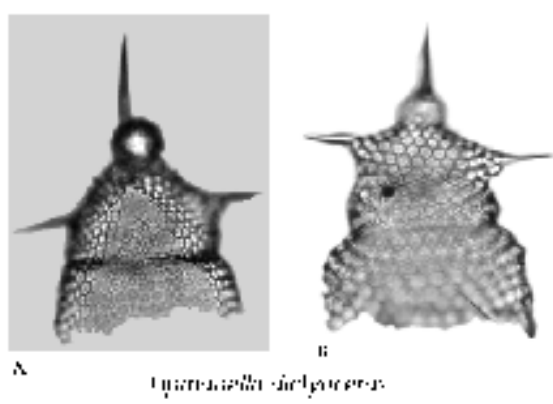

Lipmanella dictyoceras (Haeckel) (Figure 3R, 15.134) [=Lipmanella virchowii, Dictyoceras virchowii, Dictyoceras neglectum]. Cephalis large, hemispherical, wih a conspicuous apical horn. Thorax thin-walled, conical-inflated, with three wings (dorsal and main lateral spines). Abdomen absent or rudimentary. Shell height: 90-130 $\mu \mathrm{m}$. Ref: Petrushevskaya (1971a).

Figure 15.134. 


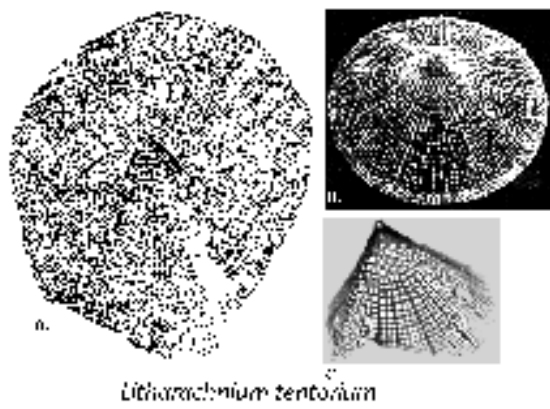

Figure 15.148.

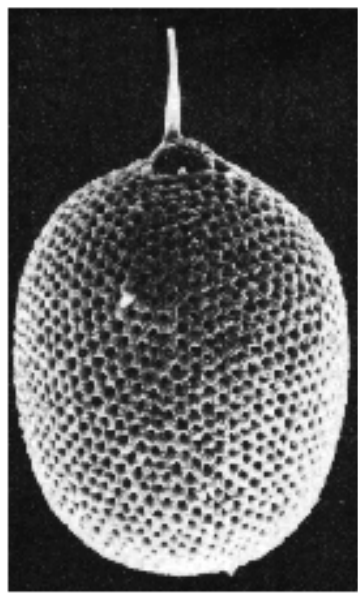

Ithopers boccs

Figure 15.129.

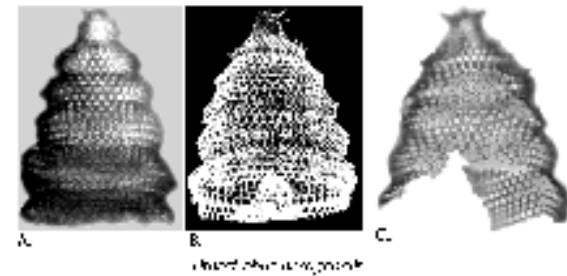

Lithostrobus hexagonalis Haeckel (Figure 15.141). Multisegmented, subconical shell with 5-9 joints with well marked strictures and angular shoulders. Pores very regular, subpolygonal, in transverse rows. Shell height: 120-300 $\mu \mathrm{m}$. Ref: Benson (1966).
Lithopera bacca Ehrenberg (Figure 15.129). Spherical, often rough cephalis with an eccentrically located apical horn partly submerged into an oval thorax with closed mouth. Pores on thorax regularly arranged. Shell height: 120-140 $\mu \mathrm{m}$. Ref: Benson (1966).

Figure 15.141. 


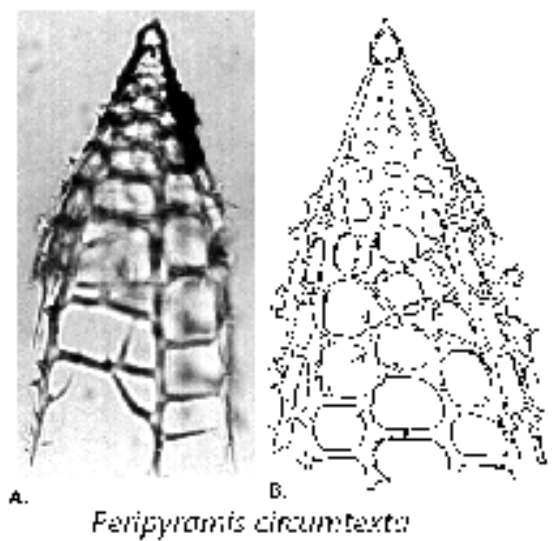

Figure 15.130.

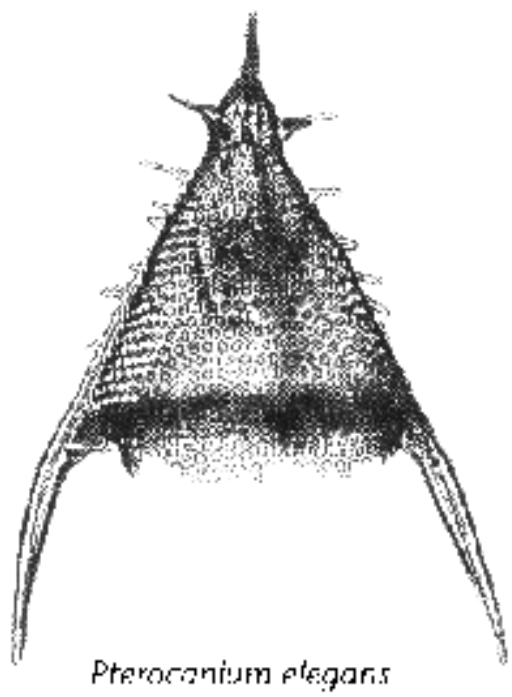

Figure 15.147.

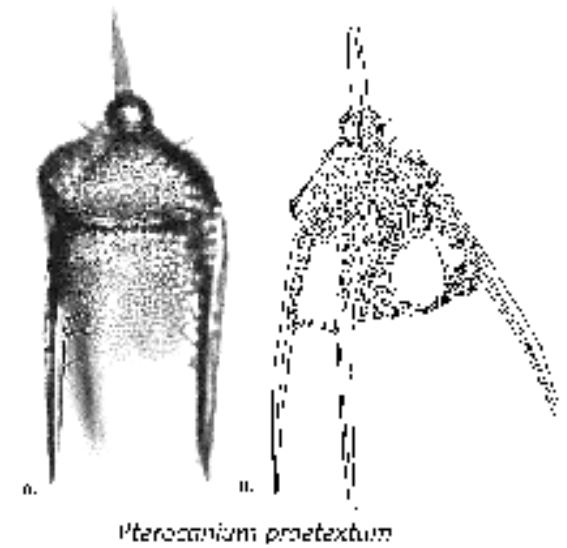

Figure 15.146.
Perypiramis circumtexta Haeckel (Figure 15.130) [=?Plectopyramis dodecomma]. Cephalis very small, ovate, hyaline. Thorax large, conical, with ca. 10 well defined longitudinal rows of subquadrate pores rapidly increasing in size toward the base. Pores are usually not aligned transversely. The form described as Plectopyramis dodecomma Haeckel differs from $P$. circumtexta in that pores are aligned transversely as well as longitudally. Bathropyramis woodringi is also similar to the above, but has thicker longitudinal bars and aligned horizontal (transverse) bars. Shell height: 100-300 $\mu \mathrm{m}$. Ref: Riedel (1958), Nigrini and Moore (1979).

Pterocanium elegans (Haeckel) (Figure 15.147).

Cephalis relatively small, with two large horns (apical and vertical spines). Thorax a large, thin-walled, three-sided pyramid with small, very regular subcircular pores and thin bars; edges of pyramid continue as three strong three-bladed legs. Abdomen cylindrical, may be rudimentary. Shell height (without horns): 180-260 $\mu \mathrm{m}$. Ref: Benson (1966), as Pterocanium cf. elegans.

Pterocanium praetextum (Ehrenberg) group? (Figure 15.146). Similar to P. trilobum, from which it sometimes is difficult to separate; differs by having a thorax with more pronounced, angular shoulders, and often a better developed abdomen. Shell height (without horn and feet):

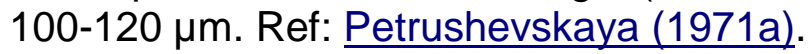




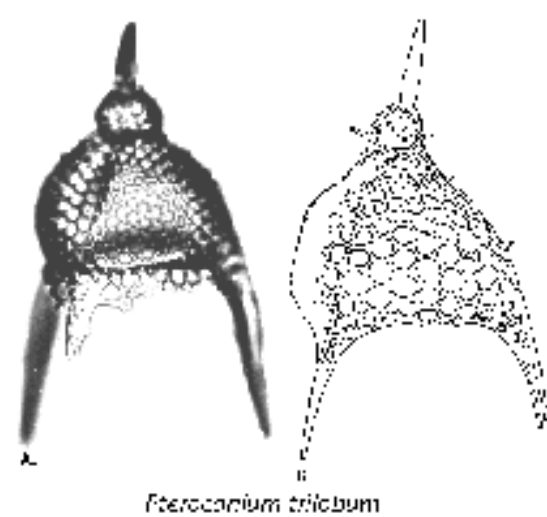

Figure 15.145.

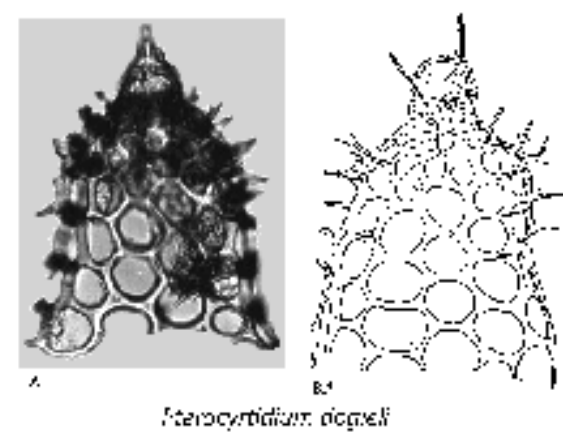

Figure 15.144.
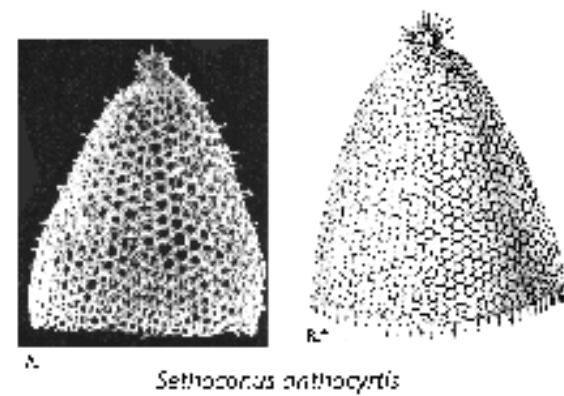

Figure 15.150.

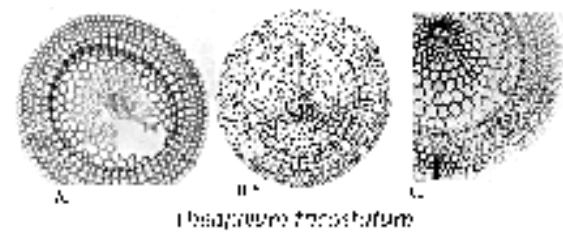

Figure 15.149.
Pterocanium trilobum (Haeckel) (Figure 3H; 15.145). Cephalis relatively small, with a stout apical horn. Thorax an inflated tetrahedron with regularly arranged circular pores, with three ribs extending into stout, three-bladed, slightly curved feet. Abdomen, when present, rudimentary. Shell height (without horn and feet): 100$120 \mu \mathrm{m}$. Ref: Nigrini and Moore (1979).
Pterocyrtidium dogieli Petrushevskaya (Figure 15.144) [=Sethoconus dogieli]. Cephalis hemispherical, almost poreless, thick-walled. Thorax cylindrical, thorny, with very large, irregular, subcircular pores. Shell height: ca. $140 \mu \mathrm{m}$. Ref: Petrushevskaya (1971a).
Sethoconus anthocyrtis Haeckel (Figure 15.150) [=Conarachnium polyacanthum, Lophocorys polyacantha]. Cephalis spherical, spiny. Thorax clearly differentiated from cephalis, very large, conical, spiny, with large, regular, subpolygonal pores approximately in longitudinal rows; termination ragged. Shell height: $200-$ $300 \mu \mathrm{m}$. Ref: Haeckel (1887). 


\section{Order Nassellaria}

\section{Family Carpocaniidae}
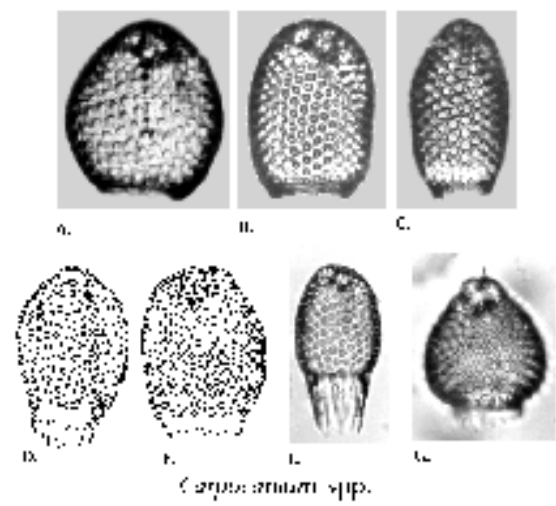

Figure 15.170.
Carpocanium spp. (Figure 3E, 15.170) [=Carpocanistrum spp.]. Shell outline subspherical to oval. Cephalis indistingishable from thorax, included within its upper part. Peristome poreless, smooth or provided with teeth. Height of shell: 80-130 $\mu \mathrm{m}$. Ref: Nigrini and Moore (1979). 


\section{Order Nassellaria}

\section{Family Pterocorythidae}

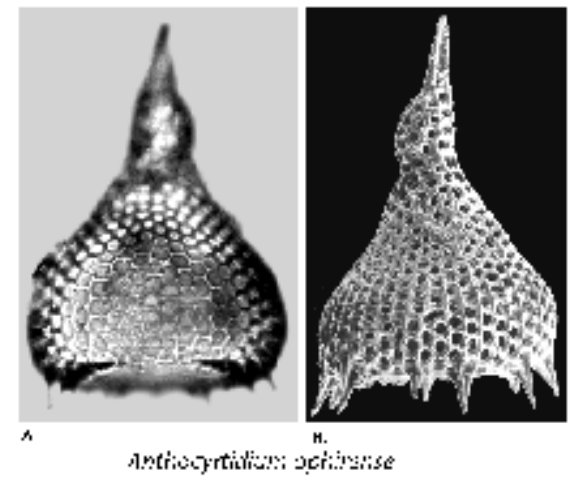

Anthocyrtidium ophirense (Ehrenberg) (Figure 15.152). Cephalis elongate with a large three-bladed apical horn. Thorax campanulate, with circular, regular pores arranged hexagonally; peristome distinct, constricted, may bear terminal teeth. Abdomen absent. Maximum breadth of thorax: 90-140 $\mu \mathrm{m}$. Ref: Nigrini and Moore (1979).

Figure 15.152.

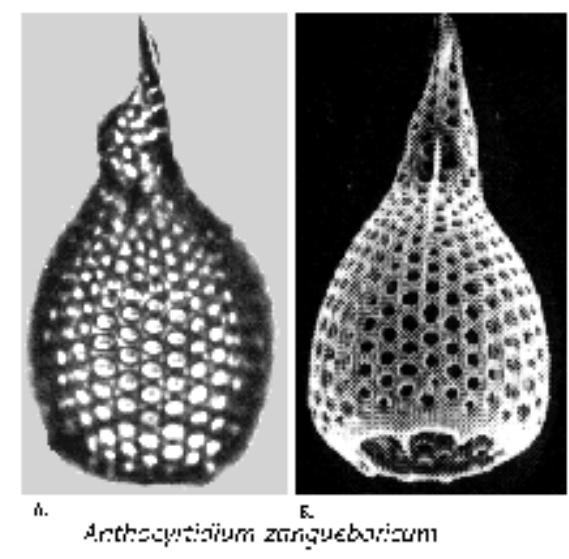

Anthocyrtidium zanguebaricum (Ehrenberg) (Figure 15.153). Similar to $A$. ophirense, but apical horn is smaller, thorax less campanulate, narrower, and terminal teeth smaller or absent. Maximum breadth of thorax: 60$80 \mu \mathrm{m}$. Ref: Nigrini and Moore (1979).

Figure 15.153. 

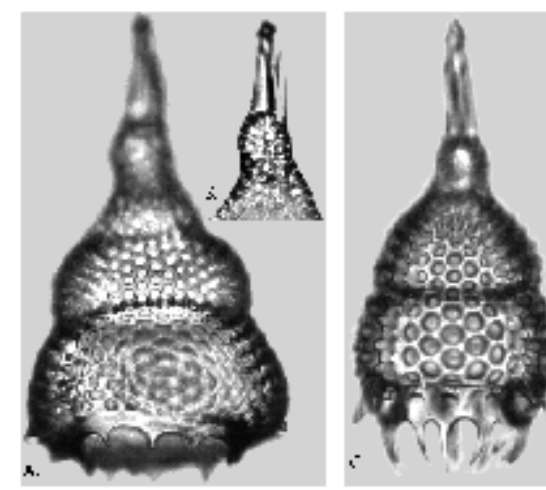

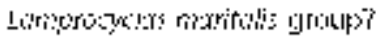

Figure 15.158.

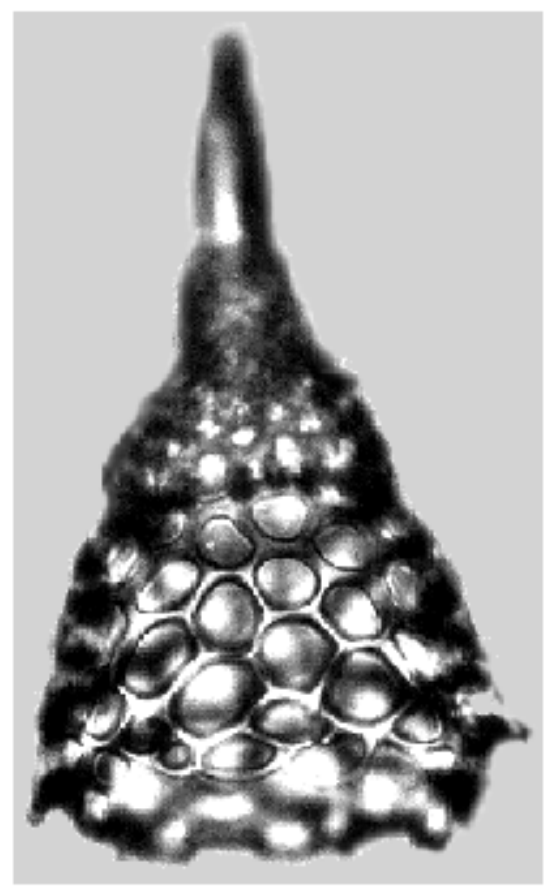

Lamprocyrtis hannai Campbell and Clark (Figure 15.154) [=Lamprocyrtis hannai, Lamprocyclas junonis]. Cephalis elongate, with a large three-bladed apical horn. Thorax campanulate, thick-walled, with subregular, circular pores. Abdomen truncate-conical, with large, subregular, circular pores and usually with terminal and/or subterminal teeth. Maximum breadth of abdomen:

90-150 $\mu \mathrm{m}$. Ref: Nigrini and Moore (1979).
Lamprocyclas maritalis group? Haeckel (Figure 3P; 15.158). Massive shell; cephalis oval, with a large apical horn. Thorax cupola-shaped, with regular, circular, framed pores. Abdomen separated by a conspicuous lumbar stricture, inflated, with larger, regularly arranged, framed pores, usually with a well-defined poreless perstome with teeth. L. m. maritalis Haeckel differs from L. $m$. Haeckel polypora Nigrini in having a less inflated abdomen. Maximum breadth of abdomen: 100-140 $\mu \mathrm{m}$. Ref: Nigrini and Moore (1979).

\section{Lamprocyrtis hannai}

Figure 15.154. 


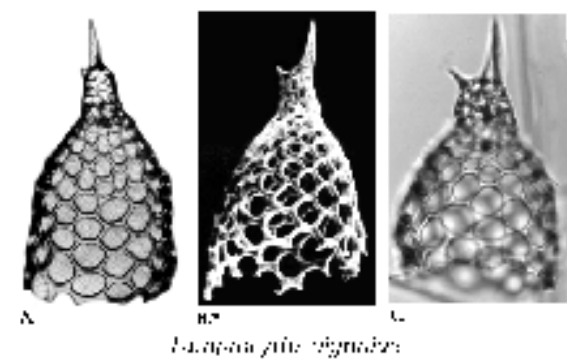

Figure 15.157.

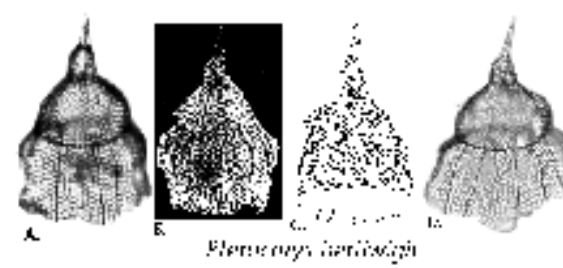

Figure 15.155.

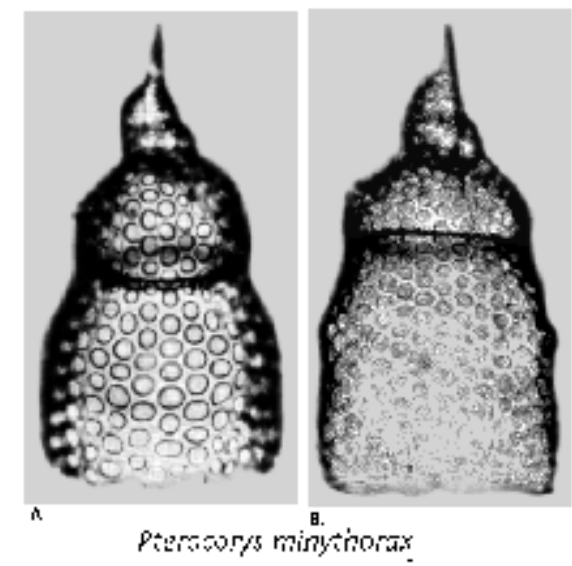

Figure 15.156.

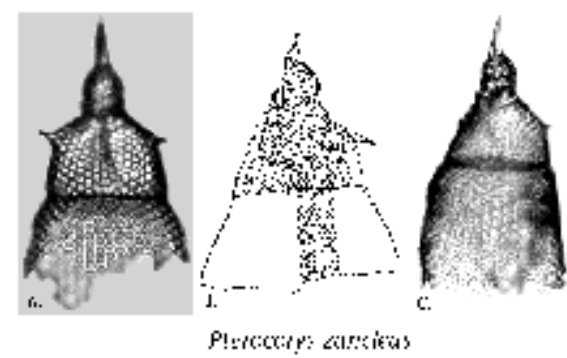

Pterocorys zancleus (Muller) (Figure 15.159) [= Theoconus zancleus, ?Pterocorys sabae, ?Pterocorys campanula]. Cephalis subcircular, horned. Thorax a truncated cone, with three small wings. Abdomen cylindrical or conical, slightly flared. Total shell height (exluding horn): 100-230 $\mu \mathrm{m}$. Ref: Benson (1966), Petrushevskaya (1971a).
Lamprocyrtis nigriniae (Caulet) (Figure 15.157) [=Conarachnium nigriniae, Lamprocyrtis haysi]. Cephalis elongated, usually open poximally, with a large threebladed horn. Thorax campanulate, thin-walled, with large, subregular, circular pores increasing in size distally; peristome absent or weakly developed. No abdomen. Maximum breadth of thorax: ca. $90 \mu \mathrm{m}$. Ref: Nigrini and Moore (1979).

Pterocorys hertwigii (Haeckel) (Figure 15.155) [=Theoconus hertwigii, Phormocyrtis fatuosa]. Cephalis oval, horned. Thorax campanulate. Abdomen conical, with ragged termination. Thorax and abdomen thinwalled, with regular circular pores in longitudinal rows, with several continuous or interrupted longitudinal poreless ribs. Total shell height (excluding horn): 120$200 \mu \mathrm{m}$. Ref: Caulet and Nigrini (1988).

Pterocorys minythorax (Nigrini) (Figure 15.156) [=Theoconus minythorax]. Cephalis subspherical, horned. Thorax small, campanulate. Abdomen comparatively large, cylindrical, slightly flared, with ragged termination. Pores on thorax and abdomen regular, circular. Total shell height (excluding horn): 120-

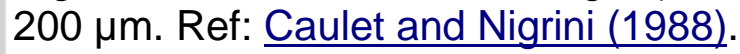

Figure 15.159. 


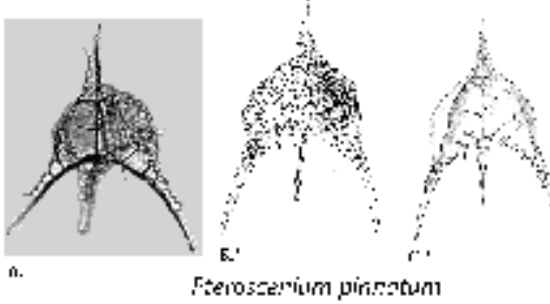

Figure 15.162.

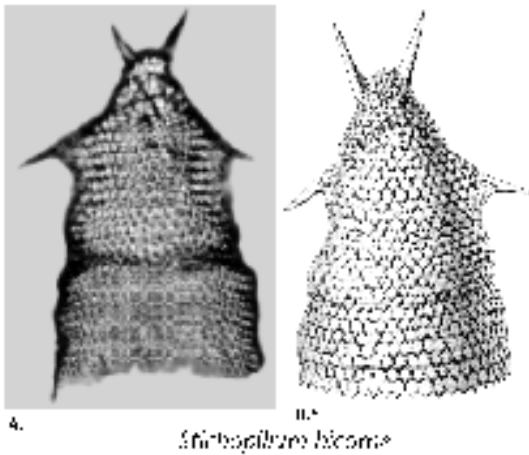

Figure 15.161.

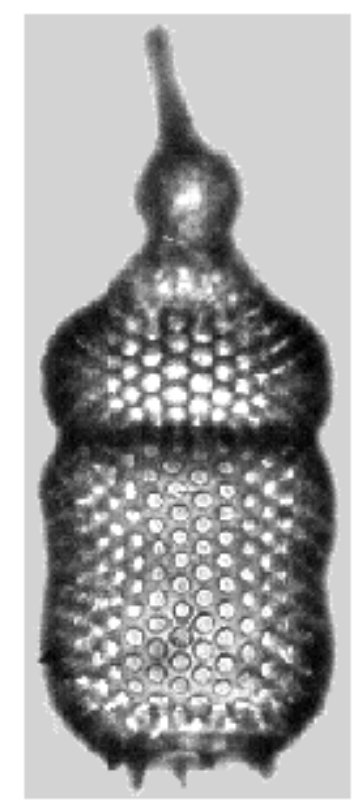

Theoconythium trachelium

Figure 15.160.
Pteroscenium pinnatum Haeckel (Figure 15.162) [=Verticillata hexacantha]. Campanulate one-segmented shell with delicate lattice of small, circular pores. Top of cephalis extends into a large, proximally perforated, three-bladed horn; base is prolonged into three stout, perforated, slightly bent feet. Total shell height (including horn and feet): $220-280 \mu \mathrm{m}$. Cephalis does not seem to be agree with the family-level diagnosis; probably a plagoniid. Ref: Haeckel (1887), Benson (1966).

Stichopilium bicorne Haeckel (Figure 15.161). Cephalis cap-shaped, with two stout, three-bladed horns. Thorax pyramidal (proximally) to cylindrical (distally), with three conspicuous wings. One or two cylindrical post-thoracic segments. Thorax and subsequent joints with small, circular, regularly arranged pores. Although this species has traditionally been ascribed to the Pterocorythidae, its cephalis does not seem to be divided into lobes, and is therefore probably a theoperid. Ref: Haeckel (1887), Benson (1966).

Theocorythium trachelium (Ehrenberg) (Figure 15.160) [=Calocyclas amicae, Lamprocyclas trachelius, Lamprocyclas cranoides]. Cephalis spherical, with a prominent, three-bladed apical horn. Thorax campanulate, inflated. Abdomen cylindrical, with a slight medial constriction; peristome diffentiated, toothed. Pores on post-cephalic segments circular, regularly arranged. Total shell height (without horn): 150-200 $\mu \mathrm{m}$. Ref: Petrushevskaya (1971a). 


\section{Order Nassellaria}

\section{Family Artostrobiidae}

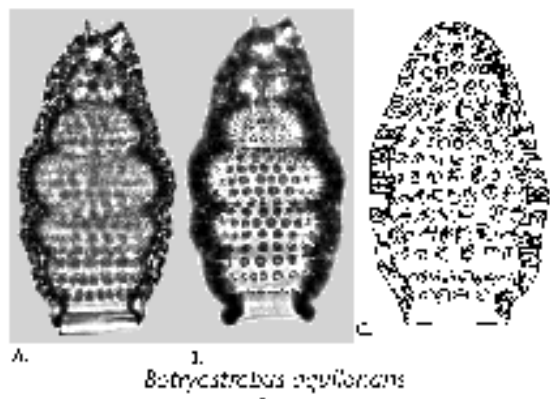

Figure 15.164.
Botryostrobus aquilonaris (Bailey) (Figure 15.164) [=Lithocampe aquilonaris]. Very thick-walled, spindleshaped skeleton with 6 poorly defined joints, of which the fourth is the broadest. Poreless peristome usually present. Shell height: 100-150 $\mu \mathrm{m}$. Ref: Nigrini and Moore (1979).

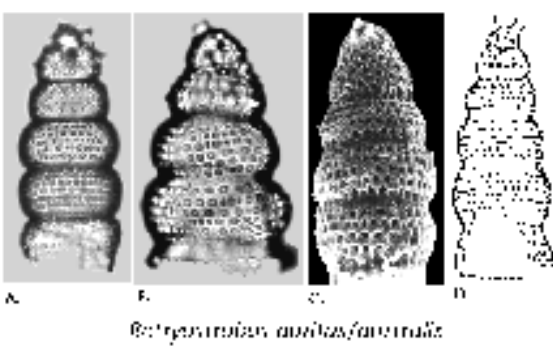

Figure 15.168.

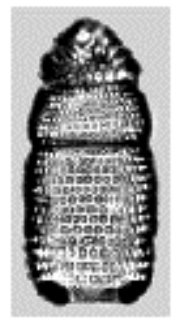

A.
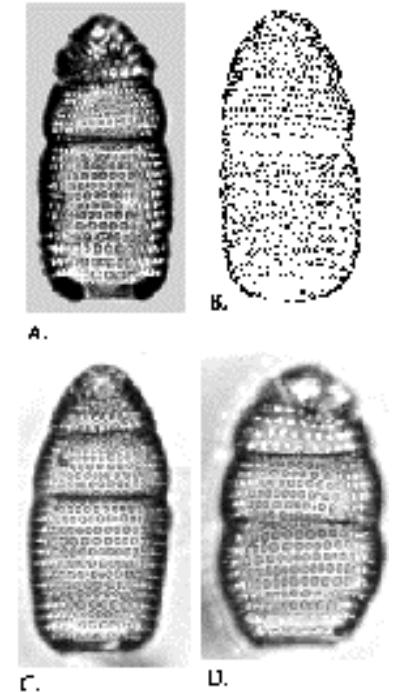

Ptyornosichoostus cortuk

Figure 15.163.
Botryostrobus auritus/australis (Ehrenberg) (Figure 3J; 15.168). [=Lithostrobus seriatus]. Multisegmented cylindrical shell of variable wall-thickness. Cephalis subspherical, apical tube and apical spine usually visible. Thorax and post-thoracic segments inflated, separated by conspicuous strictures, with three-five transverse rows of pores. Shell height: 110-200 $\mu \mathrm{m}$. Ref: Boltovskoy and Vrba (1989).

Phormostichoartus corbula (Harting) (Figure 15.163) [=Lithocampe multiseriata, Siphocampe corbula]. Foursegmented shells. Cephalis and thorax fused, thickwalled. Abdomen short, cylindrical. Last segment usually three-four times longer than previous, both with circular pores arranged regularly in transverse rows. Shell height: 130-170 $\mu \mathrm{m}$. Ref: Nigrini and Moore (1979). 


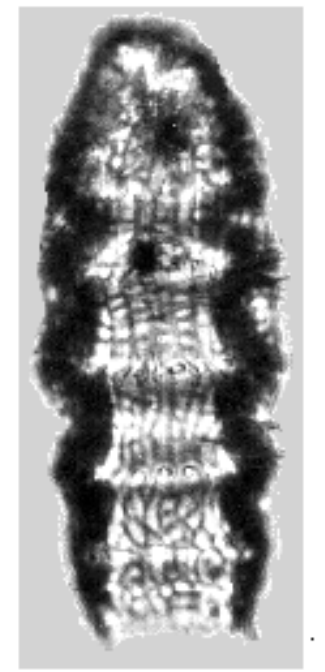

A.

Siptocampe oroctines

Figure 15.167.
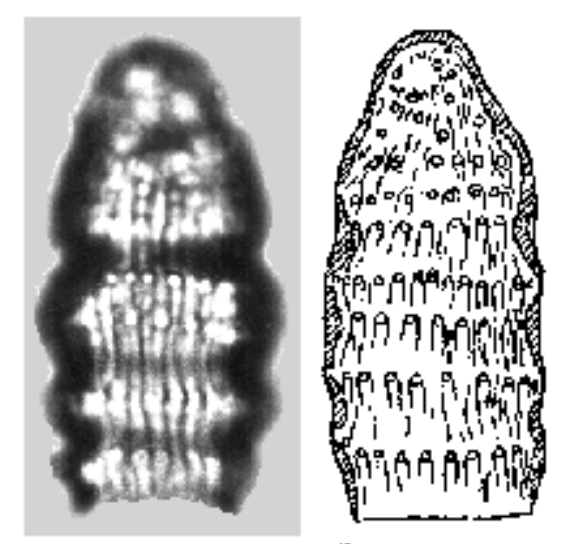

B.

Siphozampe jineato

Figure 15.169.

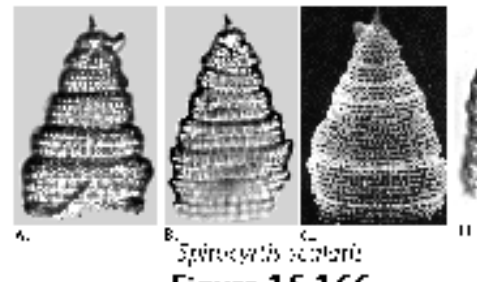

Figure 15.166.
Siphocampe lineata (Ehrenberg) (Figure 15.169) [=Lithomitra lineata, Lithomitra nodosaria, Siphocampe nodosaria]. Very similar to $S$. arachnea, except that surface ornamentation is restricted to longitudinal, sinuous ridges. Shell height: ca. 80-110 $\mu \mathrm{m}$. Ref: Petrushevskaya (1967). 

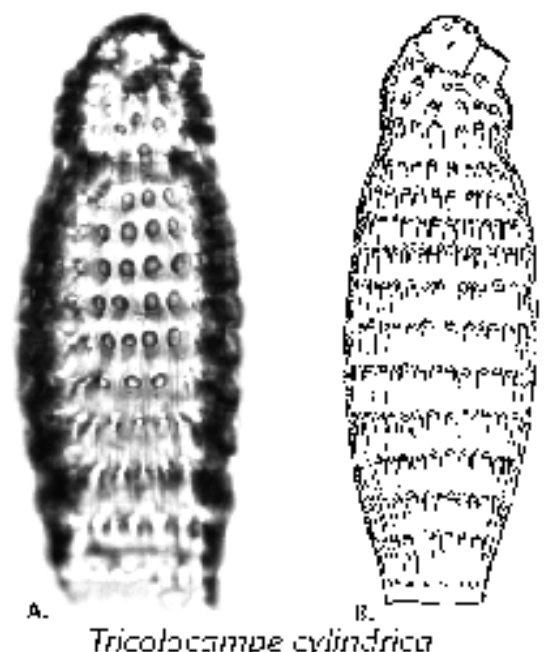

Tricolocampe cylindrica Haeckel (Figure 15.165) [=Siphocampium cylindrica]. Cephalis and thorax fused, separated from rest of shell by a conspicuous lumbar constriction. Abdomen and postabdominal section cylindrical to spindle-shaped, without external constrictions, with several very regularly arranged transverse rows of small, circular pores. Shell height: ca. $90 \mu \mathrm{m}$. Ref: Benson (1966), Pterushevskaya (1971a).

Tricolotampe cyijintricus

Figure 15.165. 


\section{Order Nassellaria}

\section{Family Cannobotryidae}

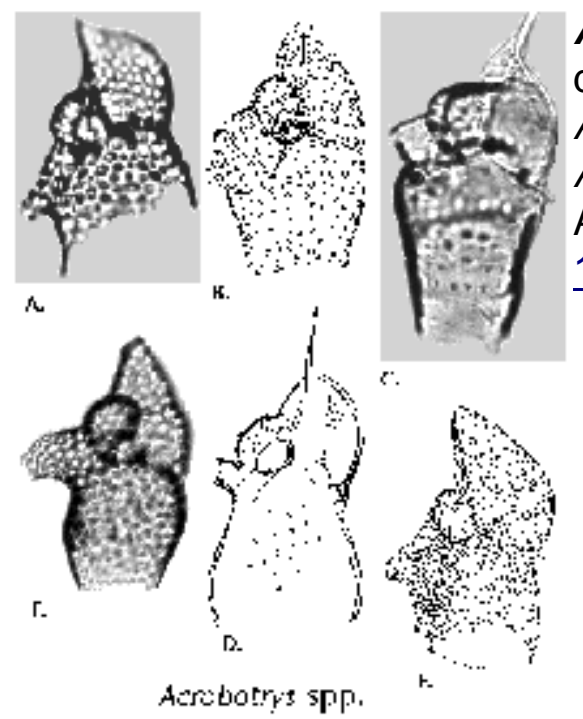

Acrobotrys spp. (Figure 3M, 3N; 15.171). Several poorly defined Cannobotryidae of variable construction (e.g., Acrobotrys sp. A, B, C in Petrushevskaya 1965; Acrobotrys cf. disolenia in Benson 1966; Acrobotrys sp. $\mathrm{A}$ and $\mathrm{B}$, Cannobotryid sp. A in Boltovskoy and Riedel 1987; etc.).

Figure 15.171.

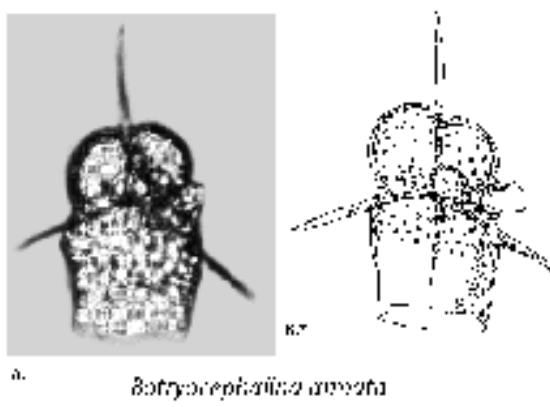

Botryocephalina armata Petrushevskaya (Figure 15.173). Main part of cephalis represented by two laterally fused hemispherical chambers of almost equal size (cephalic and antecephalic); with a long apical spine.

Figure 15.173. 


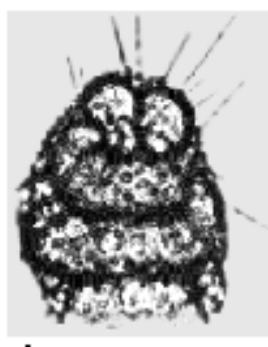

A

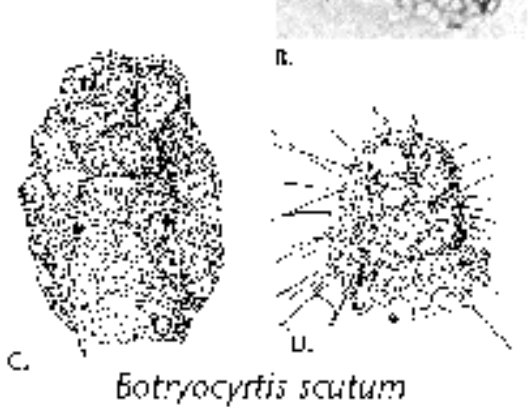

Figure 15.172.

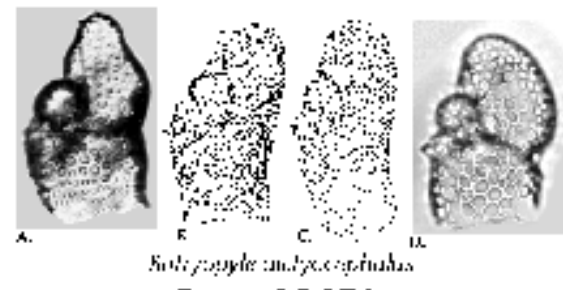

Figure 15.174.

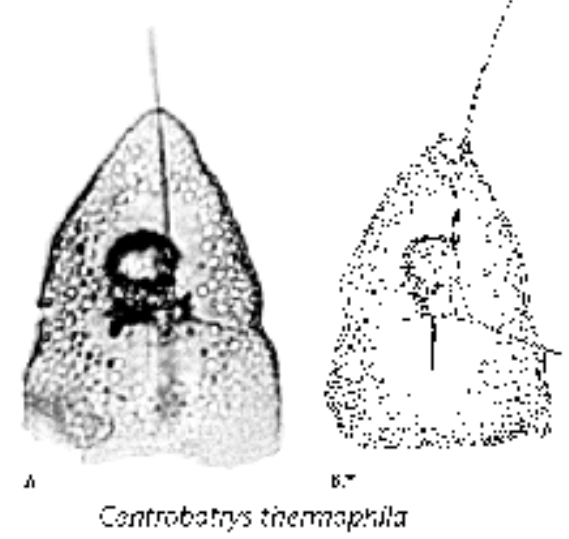

Figure 15.175.
Botryocyrtis scutum (Harting) (Figure 15.172) [=? Botryocyrtis caput-serpentis, ?Botryocyrtis quinaria]. Large, multilobed cephalis. Thorax very short, cylindrical. Abdomen longer. Sometimes one post-abdominal segment. Entire shell, and especially its upper section, enclosed in a thick, spongy mantle. Shell height: 80-130 $\mu \mathrm{m}$. Ref: Nigrini and Moore (1979).
Botryopyle dictyocephalus Haeckel (Figure 15.174). Cephalis chiefly composed of a large, ovoid, thin-walled antecephalic chamber, and a much smaller, spherical, thick-walled eucephalic chamber. Cervical constriction absent. Thorax cylindrical, with ragged temination or distally narrowing into a short, poreless tube. Shell

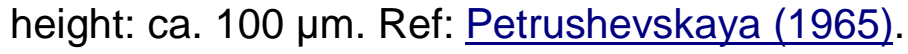

Centrobotrys thermophila Petrushevskaya (Figure $15.175)$. Shell is a laterally compressed, very thin walled, pored cone, within which the spherical, thick-walled eucephalic chamber is enclosed. Shell height: ca. 100 $\mu \mathrm{m}$. Ref: Petrushevskaya (1965). 


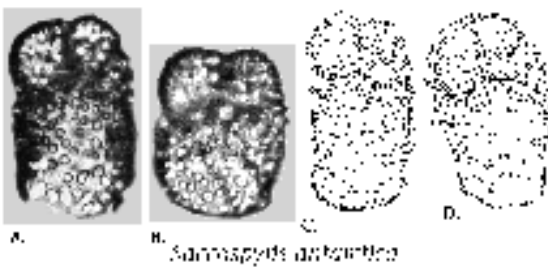

Figure 15.176.
Saccospyris antarctica Haecker (Figure 15.176).

Cephalis tri-lobulated, with the cephalic and antecephalic chambers much larger than the postcephalic one, and approximately equal in size. Thorax cylindrical, with a closed mouth in fully-grown specimens. Shell thickwalled, surface rough. Shell height: 110-160 $\mu \mathrm{m}$. Ref. : Petrushevskaya (1965). 


\section{ACKNOWLEDGMENTS}

Materials included in this article were originally prepared for the book "South Atlantic Zooplankton" (D. Boltovskoy, ed.), a ca. 2,000 pages guide on the identification and distribution of 30 zooplanktonic groups to be published in 1989 by Backhuys Publishers, The Netherlands. Permission of the publisher for electronic reproduction of this chapter in PE is acknowledged. Thanks are due to the many colleagues and publishers which kindly allowed using their published and unpublished illustrations for this work, and especially to Neil Swanberg, Petrus van de Paverd, Amy Weinheimer, and Cathy Nigrini for providing several of the photographs included. Critical reviews by Cathy Nigrini, Stanley Kling and Amy Weinheimer, as well as comments by Roger Anderson, Brian O'Connor, Luis O'Dogherty, William Riedel, and Annika Sanfilippo, were helpful for improving earlier vesions of the manuscript. This work was partly financed by grants from the University of Buenos Aires (UBA EX-040), from the Consejo Nacional de Investigaciones Científicas y Técnicas, Argentina (CONICET PID-BID 0366), and from the Agencia Nacional de Promoción Científica y Tecnológica, Argentina (BID/OC-ARPMT-PICT0395). 


\section{REFERENCES}

Abelmann, A. 1992. Radiolarian taxa from Southern Ocean sediment traps (Atlantic sector). Polar Biology, 12:373-385.

Abelmann, A., and Gowing, M. M. 1997. Spatial distribution of living polycystine radiolarian taxa baseline study for paleoenvironmental reconstructions in the Southern Ocean (Atlantic sector). Marine Micropaleontology, 30:3-28.

Alder, V. A., Thompson, G., Uliana, E., and Boltovskoy, D. 1997. Radiolarian abundance in the Southwestern Atlantic $\left(30^{\circ}-60^{\circ} \mathrm{S}\right)$ waters: latitudinal and year-to-year variations in the surface layers. Abstracts Interrad 8 (Eighth Meeting of the International Association of Radiolarian Paleontologists), Paris/Bierville, p. 8.

Alperín, M. I. 1987. Radiolarios de un testigo cuaternario del talud continental Argentino. Revista de la Asociación Geológica Argentina, 41:290-315.

Anderson, O. R. 1983a. Radiolaria. Springer Verlag, New York.

Anderson, O. R. 1983b. The Radiolarian symbiosis, p. 69-89. In Goff, L. (ed.), Algal symbiosis: a continuum of interaction strategies. Cambridge University Press, Cambridge.

Anderson, O. R. 1993. The trophic role of planktonic Foraminifera and Radiolaria. Marine Microbial Food Webs, 7:31-51.

Anderson, O. R., Nigrini, C.A., Boltovskoy, D., Swanberg, N.R., and Takahashi, K. In press. Radiolaria. In Lee, J. (ed.), An illustrated guide to the Protozoa (second edition).

Baker, A. de C., Clarke, M. R., and Harris, M. J. 1973. The N.I.O. combination net (RMT 1+8) and further developments of rectangular midwater trawls. Journal of the Marine Biological Association of the U.K., 53:167-184.

Bé, A. W. H. 1962. Quantitative multiple opening-and-closing plankton samplers. Deep-Sea Research, 9:144-151.

Bé, A. W. H., Bishop, J. K. B., Sverdlove, M. S., and Gardner, W. D. 1985. Standing stock, vertical distribution and flux of planktonic Foraminifera in the Panama Basin. Marine Micropaleontology, 9:307333.

Benson, R. N. 1966. Recent Radiolaria from the Gulf of California. Unpublished Ph.D. Thesis, University of Minnesota, USA.

Bernhard, J. M. 1988. Postmortem vital staining in benthic Foraminifera: duration and importance in population and distributional studies. Journal of Foraminiferal Research, 18:143-146.

Bett, B. J., Vanreusel, A., Vincx, M., Soltwedel, T., Pfannkuche, O., Lambshead, P. J. D., Gooday, A. J., Ferrero T., and Dinet, A. 1994. Sampler bias in the quantitative study of deep-sea meiobenthos. Marine Ecology Progress Series, 104:197-203.

Billett, D. S. M., Lampitt, R.S., Rice, A. L., and Mantoura, R. F. C. 1983. Seasonal sedimentation of phytoplankton to the deep-sea benthos. Nature, 302:520-522.

Bjørklund, K. R. 1973. Radiolarians from the surface sediment in Lindaspollene, Western Norway. Sarsia, 


\section{$53: 71-75$.}

Bjørklund, K. R. 1974. The seasonal occurrence and depth zonation of radiolarians in Korsfjorden, western Norway. Sarsia, 56:13-42.

Bjørklund, K. R., and Ciesielski, P. F. 1994. Ecology, morphology, stratigraphy, and the paleoceanographic significance of Cycladophora davisiana davisiana. Part I: Ecology and morphology. Marine Micropaleontology, 24:71-88.

Bjørklund, K. R., and Goll, R. M. 1986. Final stages of morphogenesis and early stages of disintegration for Modern polycystine Radiolaria. Marine Micropaleontology, 11:171-183.

Bjørklund, K. R., and Jansen, J. H. F. 1984. Radiolaria distribution in Middle and Late Quaternary sediments and paleoceanography in the eastern Angola Basin. Netherlands Journal of Sea Research, 17:299-312.

Bogorov, V. G., Vinogradov, M. E., Voronina, N. M., Kanaeva, I. P., and Suetova, I. A. 1968. Raspredelenie biomassy zooplanktona v poverkhnostnom sloe mirovogo okeana. Doklady Akademii Nauk SSSR, 182:1205-1208.

Boltovskoy, D. 1979. Zooplankton of the south-western Atlantic. South African Journal of Science, 75:541-544.

Boltovskoy, D. 1980. La utilización de Polycystina (Protista, Radiolaria) como indicadores hidrológicos y paleoecológicos en el Atlántico Sur. Actas del II Congreso Argentino de Paleontología y

Bioestratigrafía y I Congreso Latinoamericano de Paleontología, Buenos Aires, p. 309-314.

Boltovskoy, D. 1981a. La malla, p. 71-80. In Boltovskoy, D. (ed.), Atlas del Zooplancton del Atlántico Sudoccidental y métodos de trabajo con el zooplancton marino, Publicación Especial del Instituto Nacional de Investigación y Desarrollo Pesquero, Mar del Plata.

Boltovskoy, D. 1981b. Estimación de la cantidad de agua filtrada, p. 87-94. In Boltovskoy, D. (ed.), Atlas del Zooplancton del Atlántico Sudoccidental y métodos de trabajo con el zooplancton marino, Publicación Especial del Instituto Nacional de Investigación y Desarrollo Pesquero, Mar del Plata.

Boltovskoy, D. 1981c. Recuentos y análisis de los datos. Manipulación del material, p. 153-162. In Boltovskoy, D. (ed.), Atlas del Zooplancton del Atlántico Sudoccidental y métodos de trabajo con el zooplancton marino, Publicación Especial del Instituto Nacional de Investigación y Desarrollo Pesquero, Mar del Plata.

Boltovskoy, D. 1981d. Características biológicas del Atlántico Sudoccidental, p. 239-251. In Boltovskoy, D. (ed.), Atlas del Zooplancton del Atlántico Sudoccidental y métodos de trabajo con el zooplancton marino, Publicación Especial del Instituto Nacional de Investigación y Desarrollo Pesquero, Mar del Plata.

Boltovskoy, D. 1981e. Radiolaria, p. 261-316. In Boltovskoy, D. (ed.), Atlas del Zooplancton del Atlántico Sudoccidental y métodos de trabajo con el zooplancton marino, Publicación Especial del Instituto Nacional de Investigación y Desarrollo Pesquero, Mar del Plata.

Boltovskoy, D. 1982. Variación latitudinal de la diversidad zooplanctónica en el Atlántico Sudoccidental. Physis (Buenos Aires), A, 41:1-6.

Boltovskoy, D. 1986. Biogeography of the Southwestern Atlantic: overview, current problems and prospects, p. 14-24. In Pierrot-Bults, A. C., van der Spoel, S., Zahuranec, B. J., and Johnson, R. K. (eds.), Pelagic biogeography, UNESCO Technical Papers in Marine Science, 49. 
Boltovskoy, D. 1987. Sedimentary record of radiolarian biogeography in the equatorial to Antarctic western Pacific Ocean. Micropaleontology, 33:267-281.

Boltovskoy, D. 1988. Equatorward sedimentary shadows of near-surface oceanographic patterns. Speculations in Science and Technology, 11:219-232.

Boltovskoy, D. 1994. The sedimentary record of pelagic biogeography. Progress in Oceanography, 34:135-160.

Boltovskoy, D. 1995. Formation and deformation of the microfossil record: plankton, sediment traps and surface sediments. 1 Seminario Latino-Americano de Geoquimica Orgánica e Meio Ambiente e 1 Workshop em Paleoceanografia com enfase em Micropaleontologia e Estratigrafia, Gramado, Brasil, p. 35-41.

Boltovskoy, D., and Alder, V. A. 1992. Paleoecological implications of radiolarian distribution and standing stocks versus accumulation rates in the Weddell Sea, p. 377-384. In Kennett, J. P., and Warnke, D. A. (eds.), The Antarctic environment: a perspective on global change, Antarctic Research Series, American Geophysical Union, 56.

Boltovskoy, D., Alder, V. A., and Abelmann, A. 1993a. Annual flux of Radiolaria and other shelled plankters in the eastern equatorial Atlantic at $853 \mathrm{~m}$ : seasonal variations and polycystine species-specific responses. Deep-Sea Research, 40:1863-1895.

Boltovskoy, D., Alder, V. A., and Abelmann, A. 1993b. Radiolarian sedimentary imprint in Atlantic equatorial sediments: comparison with the yearly flux at $853 \mathrm{~m}$. Marine Micropaleontology, 23:1-12.

Boltovskoy, D., Bender Kotzian, S., and Pedrozo, F. L. 1983. Some new techniques for the preparation and illustration of Polycystina (Radiolaria). Micropaleontology, 29:382-390.

Boltovskoy, D., and Jankilevich, S. S. 1985. Radiolarian distribution in east equatorial Pacific plankton. Oceanologica Acta, 8:101-123.

Boltovskoy, D., Oberhänsli, H., and Wefer, G. 1995. Radiolarian assemblages in the eastern tropical Atlantic: patterns in the plankton and in sediment trap samples. Journal of Marine Systems, 8:31-51.

Boltovskoy, D., and Riedel, W. R. 1980. Polycystine Radiolaria from the Southwestern Atlantic ocean plankton. Revista Española de Micropaleontología, 12:99-146.

Boltovskoy, D., and Riedel, W. R. 1987. Polycystine Radiolaria of the California Current region: seasonal and geographic patterns. Marine Micropaleontology, 12:65-104.

Boltovskoy, D., Uliana, E., and Wefer, G. 1996. Seasonal variations in the flux of microplankton and radiolarian assemblage compositions in the northeastern tropical Atlantic at $2195 \mathrm{~m}$. Limnology and Oceanography, 41:615-635.

Boltovskoy, D., and Vrba, A. 1988. Classification and geographic distribution of Stylodictya - type radiolarians. Micropaleontology, 34:362-370.

Boltovskoy, D., and Vrba, A. 1989. Latitude-related shell patterns in Radiolaria: Botryostrobus auritus/australis morphotypes in the equatorial to Antarctic Pacific. Marine Micropaleontology, 13:309323.

Boltovskoy, E. 1970. Masas de agua (características, distribución, movimientos) en la superficie del Atlántico Sudoeste según indicadores biológicos - foraminíferos. Servicio de Hidrografía Naval, Argentina, Publicación H.643. 
Boltovskoy, E. 1981a. Masas de agua en el Atlántico Sudoccidental, p. 227-237. In Boltovskoy, D. (ed.), Atlas del Zooplancton del Atlántico Sudoccidental y métodos de trabajo con el zooplancton marino, Publicación Especial del Instituto Nacional de Investigación y Desarrollo Pesquero, Mar del Plata.

Boltovskoy, E. 1981b. Foraminifera, p. 317-352. In Boltovskoy, D. (ed.), Atlas del Zooplancton del Atlántico Sudoccidental y métodos de trabajo con el zooplancton marino, Publicación Especial del Instituto Nacional de Investigación y Desarrollo Pesquero, Mar del Plata.

Boltovskoy, E., Boltovskoy, D., Correa, N., and Brandini, F. 1996. Planktonic foraminifers from the Southwestern Atlantic ( 30 to $60^{\circ} \mathrm{S}$ ): species-specific patterns in the upper $50 \mathrm{~m}$. Marine Micropaleontology, 28:53-72.

Boltovskoy, E., and Lena, H. A. 1970. On the decomposition of the protoplasm and the sinking velocity of the planktonic foraminifers. Internationale Revue der Gesamten Hydrobiologie und Hydrographie, 55:797-804.

Buzas, M. A. 1990. Another look at confidence limits for species proportions. Journal of Paleontology, 64:842-843.

Cachon, J., and Cachon, M. 1972. Le système axopodial des radiolaires sphaeroidés. II. Les Periaxoplastidiés, III - Cryptoaxoplastidiés (anaxoplastidiés), IV - Les fusules et le système rheoplasmique. Archiv für Protistenkunde, 114:291-307.

Campbell, A. S. 1954. Subclass Radiolaria, p. D11-D163. In Moore, R. C. (ed.), Treatise of invertebrate paleontology. Protista 3, Geological Society of America and Kansas University Press, Lawrence, Kansas.

Caron, D. A., and Swanberg, N. R. 1990. The ecology of planktonic sarcodines. Aquatic Sciences, 3:147-180.

Caulet, J. P. 1971. Contribution a l'étude de quelques radiolaires nassellaires des boues de la Méditerranée et du Pacifique. Cahiers de Micropaléontologie, série 2, 10:1-10.

Caulet, J. P., and Nigrini, C. A. 1988. The genus Pterocorys (Radiolaria) from the tropical Neogene of the Indian and Pacific Oceans. Micropaleontology, 34:217-235.

Charles, D. C., and Morley, J.J. 1988. The paleoceanographic significance of the radiolarian Didymocyrtis tetrathalamus in eastern Cape Basin sediments. Palaeogeography, Palaeoclimatology, Palaeoecology, 66:113-126.

Cheng, Y. N., and Yeh, K. Y. 1989. Radiolaria in surface sediments from West Central Pacific near Taiwan (I). Bulletin of the National Museum of Natural Sciences, 1:177-211.

Coco, B. C. 1982. Radiolarios de un testigo antártico (Mioceno-Reciente). Ameghiniana, 19:335-352.

Dadon, J. R., and Boltovskoy, D. 1982. Zooplanktonic recurrent groups (Pteropoda, Euphausiacea, Chaetognatha) in the Southwestern Atlantic Ocean. Physis (Buenos Aires), A, 41:63-83.

Deuser, W. G., Brewer, P. G., Jickells, J. D., and Commeau, R. F. 1983. Biological control of the removal of abiogenic particles from the surface of the ocean. Science, 219:388-391.

Deuser, W. G., Müller-Karger, F. E., Evans, R. H., and Brown, O. B. 1990. Surface-ocean color and deepocean carbon flux: how close a connection? Deep-Sea Research, 37:1331-1343.

Dreyer, F. 1889. Die Pylombildungen in vergleichend-anatomischer und etwicklungsgerchichtlichen 
Beziehung bei Radiolarien und bei Protisten ueberhaupt, nebst System und Beschreibung neur und der bis jetzt bekannten pylomatischen Spumellarien. Jenaische Zeitschrift für Naturwissenschaft, 23:77214.

Dumitrica, P. 1988. New families and subfamilies of Pyloniacea (Radiolaria). Revue de Micropaléntologie, 31:178-195.

Dumitrica, P. 1989. Internal skeletal structures of the superfamily Pylonacea (Radiolaria), a basis of a new systematics. Revista Española de Micropaleontología, 21:207-264.

Dworetzky, B. A., and Morley, J. J. 1987. Vertical distribution of Radiolaria in the eastern equatorial Atlantic: analysis of a multiple series of closely-spaced plankton tows. Marine Micropaleontology, 12:119.

Foreman, H. P. 1973. Radiolaria of Leg 10 with systematics and ranges for the families Amphypyndacidae, Artostrobiidae, and Theoperidae. In Initial Rep. Deep Sea Drilling Project, US Government Printing Office, Washington D.C., 10:407-474.

Frontier, S. 1981. Cálculo del error en el recuento de organismos zooplanctónicos, p. 163-167. In Boltovskoy, D. (ed.), Atlas del Zooplancton del Atlántico Sudoccidental y métodos de trabajo con el zooplancton marino, Publicación Especial del Instituto Nacional de Investigación y Desarrollo Pesquero, Mar del Plata.

Goll, R. M. 1968. Classification and phylogeny of Trissocyclidae (Radiolaria) in the Pacific and Caribbean Bassins. Part I. Journal of Paleontology, 42:1409-1432.

Goll, R. M. 1969. Classification and phylogeny of Trissocyclidae (Radiolaria) in the Pacific and Caribbean Bassins. Part II. Journal of Paleontology, 43:322-339.

Goll, R. M. 1972. Leg 9 synthesis, Radiolaria. In Initial Rep. Deep Sea Drilling Project, US Government Printing Office, Washington D.C., 9:947-1058.

Goll, R. M. 1976. Morphological intergradation between modern populations of Lophospyris and Phormospyris (Trissocyclidae, Radiolaria). Micropaleontology, 22:379-418.

Goll, R. M. 1980. Pliocene-Pleistocene radiolarians from the East Pacific Rise and the Galapagos spreading center, Deep Sea Drilling Project Leg 54. In Initial Rep. Deep Sea Drilling Project, US Government Printing Office, Washington D.C., 54:425-453.

Goll, R. M., and Bjørklund, K. R. 1974. Radiolaria in surface sediments of the South Atlantic. Micropaleontology, 20:38-75.

Grinstead, G. P. 1984. Pliocene paleoclimatic history of the southwest Atlantic: a quantitative micropaleontological approach. Unpublished Ms.Sci. Thesis, University of Georgia.

Haeckel, E. 1862. Die Radiolarien (Rhizopoda Radiaria). Eine Monographie. Reimer, Berlin.

Haeckel, E. 1887. Report on Radiolaria collected by H.M.S. Challenger during the years 1873-1876. Rep. Sci. Res. Voyage H.M.S. Challenger 1873-76, 18:1-1803.

Hasle, G. R. 1978. The inverted-microscope method, p. 88-96. In Sournia, A. (ed.), Phytoplankton manual, UNESCO Press, Paris.

Hays, J. D. 1965. Radiolaria and late Tertiary and Quaternary history of Antarctic Seas. Biology of Antarctic Seas 2, Antarctic Research Series 5, American Geophysical Union, pp. 125-184. 
Hollande, A., and Enjumet, M. 1953. Contribution a l'étude biologique des Sphaerocollides (Radiolaires collodaires et Radiolaires Polycitaires) et leur parasites. I. Thalassicollidae, Physematidae,

Thalassophysidae. Annales des Sciences Naturelles, Zoologie, 15:99-183.

Hollande, A., and Enjumet, M. 1960. Cytologie, évolution et systématique des Sphaeroidés (Radiolaires). Archives du Muséum National d'Histoire Naturelle, Paris, série 7, 7:1-134.

Honjo, S., and Doherty, K. W. 1988. Large-aperture time-series sediment traps; design objectives, construction and application. Deep-Sea Research, 35:133-149.

Honjo, S., Manganini, S. J., and Cole, J. J. 1982. Sedimentation of biogenic matter in the deep ocean.

Deep-Sea Research, 29:609-625.

Honjo, S., Manganini, S. J., and Wefer, G. 1988. Annual particle flux and a winter outburst of sedimentation in the northern Norwegian Sea. Deep-Sea Research, 35:1223-1234.

Kennett, J. P. 1982. Marine Geology. Prentice-Hall, Englewood Cliffs.

Kleijne, A. 1987. The occurrence of Acrosphaera spinosa within a colony of Collosphaera huxleyi from the North Atlantic Ocean. Plankton Newsletter, 6:21-23.

Kling, S. A. 1976. Relation of radiolarian distribution to subsurface hydrography in the North Pacific. Deep-Sea Research, 23:1043-1058.

Kling, S. A. 1977. Local and regional imprints on radiolarian assemblages from California coastal basin sediments. Marine Micropaleontology, 2:207-221.

Kling, S. A. 1978. Radiolaria, p. 203-244. In Haq, B. U., and Boersma, A. (eds.), Introduction to marine micropaleontology, Elsevier, New York.

Kling, S. A. 1979. Vertical distribution of polycystine radiolarians in the central North Pacific. Marine Micropaleontology, 4:295-318.

Kling, S. A., and Boltovskoy, D. 1995. Radiolarian vertical distribution patterns across the southern California Current. Deep-Sea Research, 42:191-231.

Koblentz-Mishke, O. I., and Vedernikov, V. I. 1977. Pervichnaya produktziya, p. 183-209. In Okeanologiya. Biologiya Okeana. 2. Biologicheskaya Produkyivnost Okeana, Nauka, Moskva.

Kruglikova, S. B. 1981. Tzirtoidei, Larkoidei i Discoidei (Radiolyarii) kak pokazateli paleoklimata. Doklady Akademii Nauk SSSR, Geologiya, 259:1427-1432.

Kruglikova, S. B. 1984. Paleoekologicheskie rekonstruktzii na osnovanii izucheniya radiolyarii. In Petrushevskaya, M. G., and Stepanyantz, S. D. (eds.), Morfologiya, ekologiya i evolutziya radiolyarii, Nauka, Leningrad.

Kruglikova, S. B. 1987. Ispolzovanie taksonov vysokogo ranga Radiolyarii dlya paleorekonstruktzii metodom faktornogo analiza. Izvestiya Akademii Nauk SSSR, Geologiya, 2:128-130.

Lange, C. B., and Boltovskoy, D. 1995. Trampas de sedimento, p. 93-118. In Alveal, K., Ferrario, M. E., Oliveira, E. C., and Zar, E. (eds.), Manual de métodos ficológicos, Universidad de Concepción, Chile.

Lombari, G., and Boden, G. 1985. Modern global radiolarian distributions. Special Publication 16A of the Cushman Foundation for Foraminiferal Research, Washington, D.C.

Longhurst, A. R. 1995. Seasonal cycles of pelagic production and consumption. Progress in 
Oceanography, 36:77-167.

Lozano, J. A., and Hays, J. D. 1976. Relationship of radiolarian assemblages to sediment types and physical oceanography in the Atlantic and western Indian Ocean sectors of the Antarctic Ocean. Memoir of the Geological Society of America, 145:303-336.

Matsuoka, A. 1992. Skeletal growth of a spongiose radiolarian Dictyocoryre truncatum in laboratory culture. Marine Micropaleontology, 19:287-297.

Matsuoka, A. 1993. Observations of living radiolarians from the surface water in the Caribbean Sea. News Osaka Micropaleontologists, special volume 9:349-363.

Moore, T. C. 1973. Method of randomly distributing grains for microscopic examination. Journal of Sedimentary Petrology, 43:904-906.

Morley, J. J. 1977. Upper Pleistocene climatic variations in the South Atlantic derived from a quantitative radiolarian analysis: accent on the last 18,000 years. Unpublished Ph.D. Thesis, Columbia University.

Morley, J. J., Shemesh, A., and Abelmann A. In press. Biogenic silica dissolution in the Southern Ocean: evidence for preferential preservation of faunal component.

Müller, J. 1858. Über die Thalassicollen, Polycystinen und Acanthometren des Mittelmeeres. Abhandung Königliche Akademie der Wissenschaft Berlin, 1858, p. 1-62.

Nigrini, C. A. 1967. Radiolaria in pelagic sediments from the Indian and Atlantic Oceans. Bulletin of the Scripps Institution of Oceanography, 11:1-125.

Nigrini, C. A. 1968. Radiolaria from eastern tropical Pacific sediments. Micropaleontology, 14:51-63.

Nigrini, C. A. 1971. Radiolarian zones in the Quaternary of the Equatorial Pacific Ocean, p. 443-461. In Riedel, W. R., and Funnell, B. M. (eds.), The micropalaeontology of oceans, Cambridge University Press, Cambridge.

Nigrini, C. A., and Moore, T. C. 1979. A guide to Modern Radiolaria. Special Publication 16 of the Cushman Foundation for Foraminiferal Research, Washington, D.C.

Nishimura, A., Nakaseko, K., and Okuda, Y. 1997. A new coastal water radiolarian assemblage recovered from sediment samples from the Antarctic Ocean. Marine Micropaleontology, 30:29-44.

Palmer, A. A. 1986. Cenozoic radiolarians as indicators of neritic versus oceanic conditions in continentalmargin deposits: U.S. Mid-Atlantic Coastal Plain. Palaios, 1:122-132.

Patterson, R. T., and Fishbein, E. 1989. Re-examination of the statistical methods used to determine the number of point counts needed for micropaleontological quantitative research. Journal of Paleontology, 63:245-248.

Paverd, P. J. van de. 1995. Recent polycystine Radiolaria from the Snellius-II expedition.

Unpublished Ph.D. Thesis, University of Amsterdam.

Petrushevskaya, M. G. 1962. Znachenie rosta skeleta radiolyarii dlya sistematiki. Zoologicheskii Zhurnal, 41:331-341.

Petrushevskaya, M. G. 1965. Osobennosti konstruktsii skeleta radiolyarii Botryoidae (otr. Nassellaria). Trudy Zoologicheskogo Instituta Akademii Nauk SSSR, 35:79-118. 
Petrushevskaya, M. G. 1967. Radiolyarii otryadov Spumellaria i Nassellaria Antarkticheskoi oblasti (po materialam Sovetskoi Antarkticheskoi Ekspeditzii). Issledovaniya Fauny Morei, Nauka, Leningrad, 9(12), 3:5-186.

Petrushevskaya, M. G. 1971a. Radiolyarii Nassellaria v planktone Mirovogo Okeana. Issledovaniya Fauny Morei, Nauka, Leningrad, 9(17):5-186.

Petrushevskaya, M. G. 1971b. Spumellarian and nassellarian Radiolaria in the plankton and botton sediments of the Central Pacific, p. 309-317. In Riedel, W. R., and Funnell, B. M. (eds.), The micropalaeontology of oceans, Cambridge University Press, Cambridge.

Petrushevskaya, M. G. 1971c. Radiolaria. In Polevoi Opredelitel Planktona, Zoologicheskii Institut Akademii Nauk SSSR, Leningrad.

Petrushevskaya, M. G. 1981. Radiolyarii otryada Nassellaria Mirovogo Okeana. Nauka, Leningrad.

Petrushevskaya, M. G. 1986. Radiolyarevyi analiz. Nauka, Leningrad.

Petrushevskaya, M. G., Cachon, J., and Cachon, M. 1976. Comparative-morphological study of radiolarians: foundations of new taxonomy. Zoologicheskii Zhurnal, 55:485-496.

Petrushevskaya, M. G., and Swanberg, N. R. 1990. Variability in skeletal morphology of colonial Radiolaria (Actinopoda: Polycystinea: Collosphaeridae). Micropaleontology, 36:65-85.

Pisias, N. G., and Moore, T. C. 1978. Cenozoic radiolarians from Deep Sea Drilling Project leg 40. In Initial Rep. Deep Sea Drilling Project, US Government Printing Office, Washington D.C., 40:845-856.

Popofsky, A. 1913. Die Nassellarien des Warmwassergebietes. Deutsche Südpolar-Expedition 19011903, 14(Zoologie 6):217-416.

Renz, G. W. 1976. The distribution and ecology of Radiolaria in the Central Pacific: plankton and surface sediments. Bulletin of the Scripps Institution of Oceanography, 22:1-267.

Riedel, W. R. 1957. Radiolaria: a preliminary stratigraphy. Reports of the Swedish Deep-Sea Expedition, 6(3):59-96.

Riedel, W. R. 1958. Radiolaria in Antarctic sediments. Reports of the British-Australian-New Zealand Antarctic Research Expedition 1929-31, B, 6(10):219-255.

Riedel, W. R. 1967a. An annotated and indexed bibliography of polycystine Radiolaria. Scripps Inst. Oceanogr. (unpublished report).

Riedel, W. R. 1967b. Subclass Radiolaria, p. 291-298. In Harland, W. B. et al. (eds.), The fossil record, Geological Society of London.

Riedel, W. R. 1971. Systematic classification of polycystine Radiolaria, p. 649-660. In Riedel, W. R., and Funnell, B. M. (eds.), The micropalaeontology of oceans, Cambridge University Press, Cambridge.

Riedel, W. R., and Foreman, H. P. 1995. Catalogue of polycystine Radiolaria. US National Technical Information Service, NTIS ID Number PB281000/LC.

Riedel, W. R., and Sanfilippo, A. 1977. Cainozoic Radiolaria, p. 847-912. In Ramsay, A. T. S. (ed), Oceanic Micropaleontology, Academic Press, London.

Riedel, W. R., and Sanfilippo, A. 1986. Morphological characters for a natural classification of Cenozoic Radiolaria, reflecting phylogenesis. Marine Micropaleontology, 11:151-170. 
Robson, S. 1983. The distribution of Recent Radiolaria in surficial sediments of the continental margin off northern Namibia. Journal of Micropaleontology, 2:31-38.

Sanfilippo, A., and Riedel, W. R. 1970. Post-Eocene "closed" theoperid radiolarians. Micropaleontology, 16:446-462.

Sanfilippo, A., and Riedel, W. R. 1980. A revised generic and suprageneric classification of the artiscins (Radiolaria). Journal of Paleontology, 54:1008-1011.

Sanfilippo, A., Westbeg-Smith, M. J., and Riedel, W. R. 1985. Cenozoic Radiolaria. In Bolli, H. M., Sunders, J. B., and Perch-Nielsen, K. (eds.), Plankton stratigraphy, Cambridge University Press, Cambridge.

Schaaf, A. 1981. Introduction à la morphologie évolutive: une application à la classe des radiolaires. Neue Jahrbuch für Geologie und Paläontologie, Abhandlung, 161:209-253.

Semina, G. I. 1977. Fitoplankton, p. 58-62. In Okeanologiya. Biologiya Okeana. 1. Biologicheskaya Struktura Okeana, Nauka, Moskva.

Simonsen, R. 1974. The diatom plankton of the Indian Ocean Expedition of R.V. "Meteor" 1964-65. "Meteor" Forschung-Ergebnisse, D19:1-66.

Steineck, P. L., and Casey, R. E. 1990. Ecology and paleoecology of Foraminifera and Radiolaria, p. 46138. In Capriulo, G. M. (ed.), Ecology of marine Protozoa, Oxford University Press, New York.

Strelkov, A. A., and Reshetnjak, V. V. 1971. Koloniyalnie radiolyarii Spumellaria mirovogo okeana. Issledovaniya Fauny Morei, Nauka, Leningrad, 9(17):295-373.

Swanberg, N. R. 1979. The ecology of colonial radiolarians: their colony morphology, trophic interactions and associations, behavior, distribution, and the photosynthesis of their symbionts. Unpublished Ph.D. Thesis, Woods Hole Oceanographic Institution, Woods Hole, Massachussetts.

Swanberg, N. R., and Bjørklund, K. R. 1986. The radiolarian fauna of western Norwegian fjords: patterns of abundance in the plankton. Marine Micropaleontology, 11:231-241.

Swanberg, N. R., and Bjørklund, K. R. 1987. Radiolarians in the plankton of some fjords in western and northern Norway: the distribution of species. Sarsia, 72:231-244.

Swanberg, N. R., and Bjørklund, K. R. 1992. The radiolarian fauna of western Norwegian fjords: a multivariate comparison of the sediment and plankton assemblages. Micropaleontology, 38:57-74.

Swanberg, N. R., and Eide, L. K. 1992. The radiolarian fauna at the ice edge in the Greenland Sea during summer, 1988. Journal of Marine Research, 50:297-320.

Takahashi, K. 1981. Vertical flux, ecology and dissolution of Radiolaria in tropical oceans: implications for the silica cycle. Unpublished Ph.D. Thesis, Woods Hole Oceanographic Institution and Massachussetts Institute of Technology.

Takahashi, K. 1991. Radiolaria: flux, ecology, and taxonomy in the Pacific and Atlantic. Ocean Biocoenosis Series 3, Woods Hole Oceanographic Institution.

Takahashi, K., and Honjo, S. 1981. Vertical flux of Radiolaria: a taxon-quantitative sediment trap study from the western tropical Atlantic. Micropaleontology, 27:40-190.

Takahashi, K., and Honjo, S. 1983. Radiolarian skeletons: size, weight, sinking speed, and residence time in tropical pelagic oceans. Deep-Sea Research, 30:543-568. 
Tranter, D. J., and Smith, P. E. 1968. Filtration performance, p. 27-56. In Zooplankton sampling, UNESCO Press, Paris.

Tucker, G. H. 1951. Relation of fishes and other organisms to the scattering of underwater sound. Journal of Marine Research, 10:215-238.

US GOFS. 1989. Sediment trap technology and sampling. Report of the US GOFS Working Group on sediment trap technology and sampling.

Venrick, E. L. 1978. How many cells to count? p. 167-180. In Sournia, A. (ed.), Phytoplankton manual, UNESCO Press, Paris.

Venrick, E. L. 1995. Muestreo y submuestreo de fitoplancton marino y dulceacuícola, p. 199-218. In Alveal, K., Ferrario, M. E., Oliveira, E. C., and Zar, E. (eds.), Manual de métodos ficológicos, Universidad de Concepción, Chile.

Villafañe, V. E., and Reid, F. M. H. 1995. Métodos de microscopía para la cuantificación del fitoplancton, p. 169-185. In Alveal, K., Ferrario, M. E., Oliveira, E. C., and Zar, E. (eds.), Manual de métodos ficológicos, Universidad de Concepción, Chile.

Weaver, F. W. 1983. Cenozoic radiolarians from the Southwest Atlantic, Falkland Plateau region, Deep Sea Drilling Project leg 71. In Initial Rep. Deep Sea Drilling Project, US Government Printing Office, Washington D.C., 71:667-686.

Wefer, G. 1989. Particle flux in the ocean: effects of episodic production, p. 139-153. In Berger, W. H., Smetacek, V. S., and Wefer, G. (eds.), Productivity of the ocean: present and past, Wiley, Berlin.

Weinheimer, A. L. 1994. Radiolarian and diatom fluxes in two California Borderland basins as indices of climate variability. Unpublished Ph.D. Thesis, University of California, Santa Barbara.

Welling, L. A. 1990. Radiolarian microfauna in the northern California current system: spatial and temporal variability and implications for paleoceanographic reconstructions. Unpublished Ms.Sci. Thesis, Oregon State University.

Wiebe, P. H., Burt, K. H., Boyd, S. H., and Morton, A. W. 1976. A multiple opening/closing net and enviromental sensing system for sampling zooplankton. Journal of Marine Research, 34:313-326.

Zhamoida, A. I., and Kozlova, G. E. 1971. Sootnoshenie podotryadov i semeistv v otryade Spumellaria, radiolyarii. Trudy Vsesoyuznogo Neftyanogo Nauchno-Issledovatelskogo Geologorazvedochnogo Instituta, 291:76-82. 
Table 1. General distributional data for the polycystine species treated. Geographic distribution areas refer to those indicated in Figure 11. Most abundant species are denoted with bold lettering. Numbers in body of table indicate approximate pecentage contribution to the correponding assemblages; 10 : between 5 and slightly over $10 \%$, exceptionally up to $20-30 \% ; 5$ : up to $5 \%$, usually around 1-3\%; A: abundant; P: present. Depths defined are those of peak abundance of the species as derived from various reports, mostly based on materials from the Pacific Ocean. These vertical ranges are probably generally valid for middle and low latitudes, but not for the Subantarctic and Antarctic areas.

\begin{tabular}{|c|c|c|c|c|c|c|c|c|}
\hline & \multicolumn{4}{|c|}{ Warm water } & & \multicolumn{2}{|c|}{ Cold water } & \multirow[b]{2}{*}{$\begin{array}{l}\text { Depth } \\
(\mathrm{m})\end{array}$} \\
\hline & \begin{tabular}{|c|} 
Equat. \\
high \\
prod.
\end{tabular} & $\begin{array}{l}\text { Equat. low } \\
\text { prod. }\end{array}$ & $\begin{array}{c}\text { Central } \\
\text { Gyre }\end{array}$ & Subtropical & |Transitional & Subantarctic & Antarctic & \\
\hline $\begin{array}{l}\text { Acanthodesmia } \\
\text { viniculata }\end{array}$ & $\mathbf{P}$ & $\mathbf{P}$ & 5 & $\mathbf{P}$ & $\mathbf{P}$ & & & 0 \\
\hline $\begin{array}{l}\text { Acanthosphaera } \\
\text { actinota }\end{array}$ & & & & $\mathbf{P}$ & $\mathbf{P}$ & & & \\
\hline $\begin{array}{l}\text { Acanthosphaera } \\
\text { dodecastyla }\end{array}$ & & $\mathbf{P}$ & $\mathbf{P}$ & $\mathbf{P}$ & $\mathbf{P}$ & & & \\
\hline $\begin{array}{l}\text { Acanthosphaera } \\
\text { pinchuda }\end{array}$ & & & $\mathbf{P}$ & $\mathbf{P}$ & $\mathbf{P}$ & & & \\
\hline $\begin{array}{l}\text { Acrosphaera } \\
\text { murrayana }\end{array}$ & 5 & $\mathbf{P}$ & $\mathbf{P}$ & $\mathbf{P}$ & $\mathbf{P}$ & & & \\
\hline $\begin{array}{l}\text { Acrosphaera } \\
\text { spinosa }\end{array}$ & & $\mathbf{P}$ & 10 & 5 & $\mathbf{P}$ & & & \\
\hline $\begin{array}{l}\text { Actinomma } \\
\text { antarcticum }\end{array}$ & & & & & $\mathbf{P}$ & 5 & 5 & 0 \\
\hline$\frac{\text { Actinomma }}{\text { arcadophorum }}$ & $\mathbf{P}$ & $\mathbf{P}$ & $\mathbf{P}$ & $\mathbf{P}$ & & & & \\
\hline \begin{tabular}{|l|} 
Actinomma \\
leptodermum \\
\end{tabular} & & & & $\mathbf{P}$ & $\mathbf{P}$ & $\mathbf{P}$ & & \\
\hline Actinomma sol & $\mathbf{P}$ & $\mathbf{P}$ & $\mathbf{P}$ & $\mathbf{P}$ & $\mathbf{P}$ & & & $0-100$ \\
\hline
\end{tabular}




\begin{tabular}{|c|c|c|c|c|c|c|c|c|}
\hline $\begin{array}{l}\text { Amphirhopalum } \\
\text { ypsilon }\end{array}$ & $\mathbf{P}$ & A & A & A & $\mathbf{P}$ & & & \\
\hline $\begin{array}{l}\text { Amphispyris } \\
\text { reticulata }\end{array}$ & A & A & A & A & $\mathbf{P}$ & & & \\
\hline $\begin{array}{l}\text { Antarctissa } \\
\text { denticulata group }\end{array}$ & & & & & & 5 & 10 & \\
\hline $\begin{array}{l}\text { Anthocyrtidium } \\
\text { ophirense }\end{array}$ & $\mathbf{P}$ & $\mathbf{P}$ & $\mathbf{P}$ & $\mathbf{P}$ & $\mathbf{P}$ & & & $25-50$ \\
\hline $\begin{array}{l}\text { Anthocyrtidium } \\
\text { zanguebaricum }\end{array}$ & A & $\mathbf{P}$ & $\mathbf{P}$ & $\mathbf{P}$ & $\mathbf{P}$ & & & \\
\hline \begin{tabular}{|l} 
Arachnocorys \\
circumtexta
\end{tabular} & $\mathbf{P}$ & $\mathbf{P}$ & $\mathbf{P}$ & $\mathbf{P}$ & $\mathbf{P}$ & & & $25-100$ \\
\hline $\begin{array}{l}\text { Arachnosphaera } \\
\text { myriacantha }\end{array}$ & $\mathbf{P}$ & $\mathbf{P}$ & $\mathbf{P}$ & $\mathbf{P}$ & & & & \\
\hline $\begin{array}{l}\text { Artostrobus } \\
\text { annulatus }\end{array}$ & $\mathbf{P}$ & $\mathbf{P}$ & $\mathbf{P}$ & $\mathbf{P}$ & $\mathbf{P}$ & $\mathbf{P}$ & A & $>100$ \\
\hline $\begin{array}{l}\text { Astrosphaera } \\
\text { hexagonalis }\end{array}$ & $\mathbf{P}$ & $\mathbf{P}$ & $\mathbf{P}$ & $\mathbf{P}$ & & & & \\
\hline $\begin{array}{l}\text { Botryocephalina } \\
\text { armata }\end{array}$ & $\mathbf{P}$ & $\mathbf{P}$ & $\mathbf{P}$ & $\mathbf{P}$ & $\mathbf{P}$ & & & \\
\hline $\begin{array}{l}\text { Botryocyrtis } \\
\text { scutum }\end{array}$ & $\mathbf{P}$ & 5 & 5 & 5 & & & & \\
\hline $\begin{array}{l}\text { Botryopyle } \\
\text { dictyocephalus }\end{array}$ & $\mathbf{P}$ & $\mathbf{P}$ & $\mathbf{P}$ & $\mathbf{P}$ & $\mathbf{P}$ & & & \\
\hline \begin{tabular}{|l} 
Botryostrobus \\
aquilonaris
\end{tabular} & & & & & & $\mathbf{P}$ & 5 & $>100$ \\
\hline \begin{tabular}{|l} 
Botryostrobus \\
auritus/australis
\end{tabular} & $\mathbf{P}$ & $\mathbf{P}$ & $\mathbf{P}$ & $\mathbf{P}$ & 5 & 5 & $\mathbf{P}$ & 100 \\
\hline $\begin{array}{l}\text { Buccinosphaera } \\
\text { invaginata }\end{array}$ & & $\mathbf{P}$ & A & $\mathbf{P}$ & $\mathbf{P}$ & & & \\
\hline
\end{tabular}




\begin{tabular}{|c|c|c|c|c|c|c|c|c|}
\hline Callimitra carolotae & $\mathbf{P}$ & $\mathbf{P}$ & $\mathbf{P}$ & $\mathbf{P}$ & & & & \\
\hline $\begin{array}{l}\text { Carpocanium } \\
\text { spp. }\end{array}$ & $\mathbf{P}$ & $\mathbf{P}$ & 5 & $\mathbf{P}$ & $\mathbf{P}$ & & & 0 \\
\hline $\begin{array}{l}\text { Carposphaera } \\
\text { acanthophora }\end{array}$ & $\mathbf{P}$ & $\mathbf{P}$ & $\mathbf{P}$ & A & $\mathbf{P}$ & & & \\
\hline $\begin{array}{l}\text { Cenosphaera } \\
\text { spp. }\end{array}$ & & & 5 & 5 & 5 & 5 & $\mathbf{P}$ & \\
\hline $\begin{array}{l}\text { Centrobotrys } \\
\text { thermophila }\end{array}$ & $\mathbf{P}$ & $\mathbf{P}$ & $\mathbf{P}$ & $\mathbf{P}$ & & & & \\
\hline $\begin{array}{l}\text { Centrocubus } \\
\text { cladostylus }\end{array}$ & $\mathbf{P}$ & $\mathbf{P}$ & $\mathbf{P}$ & $\mathbf{P}$ & $\mathbf{P}$ & & & \\
\hline $\begin{array}{l}\text { Cephalospyris } \\
\text { clathrobursa }\end{array}$ & & & & $\mathbf{P}$ & $\mathbf{P}$ & & & \\
\hline $\begin{array}{l}\text { Cladococcus } \\
\text { cervicornis }\end{array}$ & $\mathbf{P}$ & $\mathbf{P}$ & $\mathbf{P}$ & $\mathbf{P}$ & $\mathbf{P}$ & & & \\
\hline $\begin{array}{l}\text { Cladococcus } \\
\text { megaceros }\end{array}$ & $\mathbf{P}$ & $\mathbf{P}$ & $\mathbf{P}$ & $\mathbf{P}$ & $\mathbf{P}$ & & & \\
\hline $\begin{array}{l}\text { Clathrocanium } \\
\text { coarctatum }\end{array}$ & $\mathbf{P}$ & $\mathbf{P}$ & $\mathbf{P}$ & A & & & & 0 \\
\hline $\begin{array}{l}\text { Clathrocorys } \\
\text { teuscheri }\end{array}$ & A & $\mathbf{P}$ & $\mathbf{P}$ & $\mathbf{p}$ & $\mathbf{P}$ & & & \\
\hline $\begin{array}{l}\text { Clathrocyclas } \\
\text { cassiopeiae }\end{array}$ & $\mathbf{P}$ & $\mathbf{P}$ & $\mathbf{P}$ & $\mathbf{P}$ & & & & \\
\hline $\begin{array}{l}\text { Collosphaera } \\
\text { huxleyi }\end{array}$ & & $\mathbf{P}$ & A & $\mathbf{P}$ & $\mathbf{P}$ & & & \\
\hline $\begin{array}{l}\text { Collosphaera } \\
\text { macropora }\end{array}$ & & $\mathbf{P}$ & A & $\mathbf{P}$ & $\mathbf{P}$ & & & \\
\hline $\begin{array}{l}\text { Collosphaera } \\
\text { tuberosa }\end{array}$ & & $\mathbf{P}$ & A & $\mathbf{P}$ & $\mathbf{P}$ & & & \\
\hline Cornutella & $\begin{array}{l}\text { Cos } \\
\text { mop }\end{array}$ & & & & & & & $>100$ \\
\hline
\end{tabular}




\begin{tabular}{|c|c|c|c|c|c|c|c|c|}
\hline profunda & $\begin{array}{c}\text { olita } \\
n\end{array}$ & & & & & & & \\
\hline \begin{tabular}{|l} 
Corocalyptra \\
cervus
\end{tabular} & $\mathbf{P}$ & $\mathbf{P}$ & $\mathbf{P}$ & $\mathbf{P}$ & 5 & & & \\
\hline $\begin{array}{l}\text { Corocalyptra } \\
\text { columba }\end{array}$ & & $\mathbf{P}$ & $\mathbf{P}$ & A & $\mathbf{P}$ & & & \\
\hline \begin{tabular}{|l} 
Corocalyptra \\
kruegeri
\end{tabular} & $\mathbf{P}$ & $\mathbf{P}$ & $\mathbf{P}$ & $\mathbf{P}$ & & & & \\
\hline $\begin{array}{l}\text { Cromyechinus } \\
\text { antarctica }\end{array}$ & & & & & & & 5 & \\
\hline \begin{tabular}{|l} 
Cromyechinus \\
icosacanthus
\end{tabular} & $\mathbf{P}$ & $\mathbf{P}$ & $\mathbf{P}$ & $\mathbf{P}$ & & & & \\
\hline \begin{tabular}{|l} 
Cromyomma \\
circumtextum
\end{tabular} & $\mathbf{P}$ & $\mathbf{P}$ & $\mathbf{P}$ & $\mathbf{P}$ & & & & \\
\hline \begin{tabular}{|l} 
Cycladophora \\
davisiana
\end{tabular} & & & & & $\mathbf{P}$ & 5 & 5 & \\
\hline$\frac{\text { Cyrtopera }}{\text { laguncula }}$ & $\begin{array}{c}\text { Cos } \\
\text { mop } \\
\text { olita } \\
n ?\end{array}$ & & & & & & & $>100$ \\
\hline \begin{tabular}{|l} 
Dictyocephalus \\
papillosus
\end{tabular} & $\begin{array}{c}\text { Cos } \\
\text { mop } \\
\text { olita } \\
\text { n? }\end{array}$ & & & & & & & \\
\hline \begin{tabular}{|l} 
Dictyocoryne \\
profunda
\end{tabular} & 5 & 5 & $\mathbf{P}$ & $\mathbf{P}$ & $\mathbf{P}$ & & & 0 \\
\hline \begin{tabular}{|l} 
Dictyocoryne \\
truncatum
\end{tabular} & & $\mathbf{P}$ & $\mathbf{P}$ & $\mathbf{P}$ & $\mathbf{P}$ & & & \\
\hline \begin{tabular}{|l} 
Dictyophimus \\
gracilipes
\end{tabular} & & & & & $\mathbf{P}$ & A & 5 & 100 \\
\hline $\begin{array}{l}\text { Dictyophimus } \\
\text { hirundo }\end{array}$ & {$\left[\begin{array}{c}\text { Cos } \\
\text { mop } \\
\text { olitit }\end{array} \mid\right.$} & & & & & & & \\
\hline
\end{tabular}




\begin{tabular}{|c|c|c|c|c|c|c|c|c|}
\hline & $\mathrm{n}$ ? & & & & & & & \\
\hline $\begin{array}{l}\text { Dictyophimus } \\
\text { infabricatus }\end{array}$ & $\mathbf{P}$ & $\mathbf{P}$ & $\mathbf{P}$ & $\mathbf{P}$ & & & & \\
\hline \begin{tabular}{|l|} 
Didymocyrtis \\
tetrathalamus \\
\end{tabular} & 10 & 10 & 10 & 5 & A & & & 0 \\
\hline Dipylissa bensoni & P? & P? & P? & P? & & & & \\
\hline $\begin{array}{l}\text { Druppatractus } \\
\text { irregularis }\end{array}$ & $\mathbf{P}$ & $\mathbf{P}$ & $\mathbf{P}$ & $\mathbf{P}$ & & & & \\
\hline $\begin{array}{l}\text { Euchitonia } \\
\text { elegans/furcata } \\
\text { group? }\end{array}$ & $\mathbf{P}$ & 5 & 10 & 5 & $\mathbf{P}$ & & & 0 \\
\hline$\frac{\text { Eucyrtidium }}{\text { acuminatum }}$ & $\mathbf{P}$ & $\mathbf{P}$ & $\mathbf{P}$ & A & $\mathbf{P}$ & & & 0 \\
\hline$\frac{\text { Eucyrtidium }}{\text { anomalum }}$ & A & $\mathbf{P}$ & $\mathbf{P}$ & A & $\mathbf{P}$ & & & \\
\hline $\begin{array}{l}\text { Eucyrtidium } \\
\text { hexastichum }\end{array}$ & $\mathbf{P}$ & $\mathbf{P}$ & $\mathbf{P}$ & $\mathbf{P}$ & $\mathbf{P}$ & & & $25-100$ \\
\hline$\frac{\text { Heliaster }}{\text { hexagonium }}$ & $\mathbf{P}$ & $\mathbf{P}$ & $\mathbf{P}$ & $\mathbf{P}$ & & & & \\
\hline \begin{tabular}{|l} 
Heliodiscus \\
asteriscus
\end{tabular} & $\mathbf{P}$ & $\mathbf{P}$ & A & $\mathbf{P}$ & $\mathbf{P}$ & & & 0 \\
\hline $\begin{array}{l}\text { Heliosoma } \\
\text { echinaster }\end{array}$ & $\mathbf{P}$ & $\mathbf{P}$ & $\mathbf{P}$ & $\mathbf{P}$ & & & & \\
\hline $\begin{array}{l}\text { Helotholus } \\
\text { histricosa }\end{array}$ & & & & $\mathbf{P}$ & $\mathbf{P}$ & A & A & $0-100$ \\
\hline \begin{tabular}{|l} 
Hexacontium \\
aristarchi
\end{tabular} & $\mathbf{P}$ & $\mathbf{P}$ & $\mathbf{P}$ & $\mathbf{P}$ & $\mathbf{P}$ & & & \\
\hline \begin{tabular}{|l} 
Hexacontium \\
armatum/hostile \\
group
\end{tabular} & $\mathbf{P}$ & $\mathbf{P}$ & 5 & $\mathbf{P}$ & $\mathbf{P}$ & & & \\
\hline Hexacontium & $\mathbf{P}$ & $\mathbf{P}$ & $\mathbf{P}$ & $\mathbf{P}$ & & & & \\
\hline
\end{tabular}




\begin{tabular}{|c|c|c|c|c|c|c|c|c|}
\hline laevigatum & & & & & & & & \\
\hline $\begin{array}{l}\text { Lamprocyclas } \\
\text { hannai }\end{array}$ & P? & $\mathbf{P}$ ? & P? & P? & & & & \\
\hline $\begin{array}{l}\text { Lamprocyclas } \\
\text { maritalis group? }\end{array}$ & $\mathbf{P}$ & $\mathbf{P}$ & $\mathbf{P}$ & A & A & & & $50-100$ \\
\hline \begin{tabular}{|l} 
Lamprocyclas \\
nigriniae
\end{tabular} & $\mathbf{P}$ & $\mathbf{P}$ & $\mathbf{P}$ & $\mathbf{P}$ & & & & $100->100$ \\
\hline $\begin{array}{l}\text { Lampromitra } \\
\text { coronata }\end{array}$ & $\mathbf{P}$ & $\mathbf{P}$ & $\mathbf{P}$ & $\mathbf{P}$ & & & & \\
\hline $\begin{array}{l}\text { Lampromitra } \\
\text { danaes }\end{array}$ & $\mathbf{P}$ & $\mathbf{P}$ & $\mathbf{P}$ & $\mathbf{P}$ & & & & \\
\hline $\begin{array}{l}\text { Lampromitra } \\
\text { quadricuspis }\end{array}$ & $\mathbf{P}$ & $\mathbf{P}$ & $\mathbf{P}$ & $\mathbf{P}$ & & & & $100->100$ \\
\hline $\begin{array}{l}\text { Lampromitra } \\
\text { schultzei }\end{array}$ & $\mathbf{P}$ & $\mathbf{P}$ & $\mathbf{P}$ & $\mathbf{P}$ & & & & \\
\hline \begin{tabular}{|l} 
Larcopyle \\
butschlii
\end{tabular} & $\mathbf{P}$ & $\mathbf{P}$ & $\mathbf{P}$ & $\mathbf{P}$ & A & A & $\mathbf{P}$ & $>100$ \\
\hline $\begin{array}{l}\text { Larcospyra } \\
\text { quadrangula }\end{array}$ & $\mathbf{P}$ & A & $\mathbf{P}$ & A & $\mathbf{P}$ & & & 0 \\
\hline $\begin{array}{l}\text { Lipmanella } \\
\text { bombus }\end{array}$ & $\mathbf{P}$ & $\mathbf{P}$ & $\mathbf{P}$ & $\mathbf{P}$ & & & & \\
\hline \begin{tabular}{|l} 
Lipmanella \\
dictyoceras
\end{tabular} & $\mathbf{P}$ & $\mathbf{P}$ & $\mathbf{P}$ & $\mathbf{P}$ & 5 & & & 0 \\
\hline $\begin{array}{l}\text { Litharachnium } \\
\text { tentorium }\end{array}$ & $\mathbf{P}$ & $\mathbf{P}$ & $\mathbf{P}$ & $\mathbf{P}$ & & & & 100 \\
\hline Lithelius minor & $\mathbf{P}$ & $\mathbf{P}$ & $\mathbf{P}$ & 5 & $\mathbf{P}$ & $\mathbf{P}$ & $\mathbf{P}$ & \\
\hline \begin{tabular}{|l} 
Lithelius \\
nautiloides \\
\end{tabular} & & & & & $\mathbf{P}$ & $\mathbf{P}$ & 5 & \\
\hline Lithopera bacca & $\mathbf{P}$ & A & $\mathbf{P}$ & $\mathbf{P}$ & & & & 0 \\
\hline Lithostrobus & $\mathbf{P}$ & $\mathbf{P}$ & $\mathbf{P}$ & $\mathbf{P}$ & & & & $0-100$ \\
\hline
\end{tabular}




\begin{tabular}{|c|c|c|c|c|c|c|c|c|}
\hline hexagonalis & & & & & & & & \\
\hline $\begin{array}{l}\text { Lophophaena } \\
\text { butschlii }\end{array}$ & $\mathbf{P}$ & $\mathbf{P}$ & $\mathbf{P}$ & $\mathbf{P}$ & & & & \\
\hline $\begin{array}{l}\text { Lophophaena } \\
\text { hispida }\end{array}$ & $\mathbf{P}$ & $\mathbf{P}$ & $\mathbf{P}$ & $\mathbf{P}$ & & & & \\
\hline \begin{tabular}{|l}
$\frac{\text { Lophospyris }}{\text { pentagona }}$ \\
pentagona
\end{tabular} & $\mathbf{P}$ & $\mathbf{P}$ & $\mathbf{P}$ & $\mathbf{P}$ & & & & \\
\hline \begin{tabular}{|l|} 
Neosemantis \\
distephanus \\
\end{tabular} & $\mathbf{P}$ & $\mathbf{P}$ & $\mathbf{P}$ & $\mathbf{P}$ & & & & 0 \\
\hline $\begin{array}{l}\text { Nephrospyris } \\
\text { renilla }\end{array}$ & $\mathbf{P}$ & $\mathbf{P}$ & $\mathbf{P}$ & $\mathbf{P}$ & & & & \\
\hline $\begin{array}{l}\text { Octodendron } \\
\text { cubocentron }\end{array}$ & $\mathbf{P}$ & $\mathbf{P}$ & $\mathbf{P}$ & $\mathbf{P}$ & & & & \\
\hline \begin{tabular}{|l} 
Octopyle \\
stenozona \\
group?
\end{tabular} & 5 & 10 & 10 & 5 & 5 & & & 0 \\
\hline $\begin{array}{l}\text { Peromelissa } \\
\text { phalacra }\end{array}$ & $\mathbf{P}$ & $\mathbf{P}$ & $\mathbf{P}$ & $\mathbf{P}$ & & & & \\
\hline $\begin{array}{l}\text { Perypiramis } \\
\text { circumtexta }\end{array}$ & $\begin{array}{l}\text { Cos } \\
\text { mop } \\
\text { olita } \\
n\end{array}$ & & & & & & & $>100$ \\
\hline \begin{tabular}{|l} 
Phormacantha \\
hystrix
\end{tabular} & & & & & $\mathbf{P}$ & $\mathbf{P}$ & $\mathbf{P}$ & \\
\hline $\begin{array}{l}\text { Phormospyris } \\
\text { stabilis scaphipes }\end{array}$ & $\mathbf{P}$ & $\mathbf{P}$ & $\mathbf{P}$ & A & A & & & $25-100$ \\
\hline $\begin{array}{l}\text { Phormospyris } \\
\text { stabilis stabilis } \\
\end{array}$ & $\mathbf{P}$ & $\mathbf{P}$ & $\mathbf{P}$ & $\mathbf{P}$ & & & & \\
\hline \begin{tabular}{|l} 
Phormostichoartus \\
corbula
\end{tabular} & $\mathbf{P}$ & $\mathbf{P}$ & $\mathbf{P}$ & $\mathbf{P}$ & $\mathbf{P}$ & A & A & $100->100$ \\
\hline Phorticium clevei & & & & & & $\mathbf{P}$ & 5 & \\
\hline
\end{tabular}




\begin{tabular}{|c|c|c|c|c|c|c|c|c|}
\hline $\begin{array}{l}\text { Plagoniidae } \\
\text { group }\end{array}$ & 10 & 5 & 5 & A & A & A & 5 & \\
\hline $\begin{array}{l}\text { Plegmosphaera } \\
\text { entodictyon }\end{array}$ & $\mathbf{P}$ & $\mathbf{P}$ & $\mathbf{P}$ & $\mathbf{P}$ & & & & \\
\hline $\begin{array}{l}\text { Plegmosphaera } \\
\text { exodictyon }\end{array}$ & $\mathbf{P}$ & $\mathbf{P}$ & $\mathbf{P}$ & $\mathbf{P}$ & & & & \\
\hline $\begin{array}{l}\text { Plegmosphaera } \\
\text { pachyplegma }\end{array}$ & $\mathbf{P}$ & $\mathbf{P}$ & $\mathbf{P}$ & $\mathbf{P}$ & & & & \\
\hline $\begin{array}{l}\text { Pseudocubus } \\
\text { obeliscus }\end{array}$ & & & & $\mathbf{P}$ & $\mathbf{P}$ & $\mathbf{P}$ & 5 & \\
\hline $\begin{array}{l}\text { Pterocanium } \\
\text { elegans }\end{array}$ & $\mathbf{P}$ & $\mathbf{P}$ & $\mathbf{P}$ & $\mathbf{P}$ & & & & \\
\hline \begin{tabular}{|l} 
Pterocanium \\
praetextum \\
\end{tabular} & $\mathbf{P}$ & $\mathbf{P}$ & 5 & 5 & $\mathbf{P}$ & & & 0 \\
\hline \begin{tabular}{|l|} 
Pterocanium \\
trilobum
\end{tabular} & $\mathbf{P}$ & $\mathbf{P}$ & $\mathbf{P}$ & $\mathbf{P}$ & 5 & & & 0 \\
\hline $\begin{array}{l}\text { Pterocorys } \\
\text { herwigii }\end{array}$ & $\mathbf{P}$ & $\mathbf{P}$ & $\mathbf{P}$ & A & $\mathbf{P}$ & & & 0 \\
\hline $\begin{array}{l}\text { Pterocorys } \\
\text { minythorax }\end{array}$ & $\mathbf{P}$ & $\mathbf{P}$ & $\mathbf{P}$ & $\mathbf{P}$ & 10 & & & 0 \\
\hline $\begin{array}{l}\text { Pterocorys } \\
\text { zancleus }\end{array}$ & $\mathbf{P}$ & $\mathbf{P}$ & $\mathbf{P}$ & A & $\mathbf{P}$ & & & \\
\hline $\begin{array}{l}\text { Pterocyrtidium } \\
\text { dogieli }\end{array}$ & P? & P? & P? & P? & & & & \\
\hline \begin{tabular}{|l} 
Pteroscenium \\
pinnatum
\end{tabular} & $\mathbf{P}$ & $\mathbf{P}$ & $\mathbf{P}$ & $\mathbf{P}$ & & & & \\
\hline $\begin{array}{l}\text { Pylolena armata } \\
\text { group? }\end{array}$ & $\mathbf{P}$ & $\mathbf{P}$ & $\mathbf{P}$ & A & $\mathbf{P}$ & & & \\
\hline Pylospyra octopyle & P? & $\mathbf{P} ?$ & P? & P? & & & & \\
\hline Saccospyris & & & & & & $\mathbf{P}$ & 5 & \\
\hline
\end{tabular}




\begin{tabular}{|c|c|c|c|c|c|c|c|c|}
\hline antarctica & & & & & & & & \\
\hline $\begin{array}{l}\text { Saturnalis } \\
\text { circularis }\end{array}$ & & & & $\mathbf{P}$ & $\mathbf{P}$ & $\mathbf{P}$ & & \\
\hline $\begin{array}{l}\text { Sethoconus } \\
\text { anthocyrtis }\end{array}$ & $\mathbf{P}$ & $\mathbf{P}$ & $\mathbf{P}$ & $\mathbf{P}$ & & & & \\
\hline$\frac{\text { Sethodiscus }}{\text { macococcus }}$ & & & & $\mathbf{P}$ & $\mathbf{P}$ & & & \\
\hline $\begin{array}{l}\text { Sethophormis } \\
\text { aurelia }\end{array}$ & $\mathbf{P}$ & $\mathbf{P}$ & $\mathbf{P}$ & $\mathbf{P}$ & & & & 0 \\
\hline $\begin{array}{l}\text { Sethophormis } \\
\text { rotula }\end{array}$ & & & & & $\mathbf{P}$ & $\mathbf{P}$ & $\mathbf{P}$ & \\
\hline $\begin{array}{l}\text { Siphocampe } \\
\text { arachnea }\end{array}$ & & & & & $\mathbf{P}$ & $\mathbf{P}$ & A & $>100$ \\
\hline $\begin{array}{l}\text { Siphocampe } \\
\text { lineata }\end{array}$ & & & & & $\mathbf{P}$ & $\mathbf{P}$ & 5 & \\
\hline $\begin{array}{l}\text { Siphonosphaera } \\
\text { martensi }\end{array}$ & & A & A & $\mathbf{P}$ & $\mathbf{P}$ & & & \\
\hline $\begin{array}{l}\text { Siphonosphaera } \\
\text { polysiphonia }\end{array}$ & $\mathbf{P}$ & A & 5 & $\mathbf{P}$ & $\mathbf{P}$ & & & 0 \\
\hline $\begin{array}{l}\text { Solenosphaera } \\
\text { chierchiae }\end{array}$ & & A & A & $\mathbf{P}$ & $\mathbf{P}$ & & & \\
\hline $\begin{array}{l}\text { Solenosphaera } \\
\text { polysolenia }\end{array}$ & & A & A & $\mathbf{P}$ & $\mathbf{P}$ & & & \\
\hline $\begin{array}{l}\text { Solenosphaera } \\
\text { zanquebarica }\end{array}$ & & 5 & 5 & $\mathbf{P}$ & $\mathbf{P}$ & & & \\
\hline Spirocyrtis scalaris & $\mathbf{P}$ & $\mathbf{P}$ & $\mathbf{P}$ & $\mathbf{P}$ & & & & \\
\hline $\begin{array}{l}\text { Spongaster tetras } \\
\text { irregularis }\end{array}$ & $\mathbf{P}$ & $\mathbf{P}$ & $\mathbf{P}$ & A & & & & \\
\hline \begin{tabular}{|l|} 
Spongaster tetras \\
tetras
\end{tabular} & 5 & 5 & $\mathbf{P}$ & $\mathbf{P}$ & $\mathbf{P}$ & & & 0 \\
\hline
\end{tabular}




\begin{tabular}{|c|c|c|c|c|c|c|c|c|}
\hline $\begin{array}{l}\text { Spongocore } \\
\text { cylindrica }\end{array}$ & $\mathbf{P}$ & $\mathbf{P}$ & $\mathbf{P}$ & $\mathbf{P}$ & $\mathbf{P}$ & & & 100 \\
\hline $\begin{array}{l}\text { Spongodictyon } \\
\text { spongiosum }\end{array}$ & $\mathbf{P}$ & $\mathbf{P}$ & $\mathbf{P}$ & $\mathbf{P}$ & $\mathbf{P}$ & & & \\
\hline $\begin{array}{l}\text { Spongodiscus } \\
\text { resurgens }\end{array}$ & 5 & $\mathbf{P}$ & $\mathbf{P}$ & $\mathbf{P}$ & 10 & $\mathbf{P}$ & 5 & \\
\hline $\begin{array}{l}\text { Spongoliva } \\
\text { ellipsoides }\end{array}$ & $\mathbf{P}$ & $\mathbf{P}$ & $\mathbf{P}$ & $\mathbf{P}$ & & & & \\
\hline $\begin{array}{l}\text { Spongoplegma } \\
\text { antarcticum }\end{array}$ & & & & & $\mathbf{P}$ & & & \\
\hline $\begin{array}{l}\text { Spongoplegma } \\
\text { rugosa }\end{array}$ & $\mathbf{P}$ & $\mathbf{P}$ & $\mathbf{P}$ & $\mathbf{P}$ & & & & \\
\hline $\begin{array}{l}\text { Spongopyle } \\
\text { setosa }\end{array}$ & $\mathbf{P}$ & $\mathbf{P}$ & $\mathbf{P}$ & $\mathbf{P}$ & $\mathbf{P}$ & 5 & 5 & $>100$ \\
\hline $\begin{array}{l}\text { Spongosphaera } \\
\text { streptacantha }\end{array}$ & $\mathbf{P}$ & $\mathbf{P}$ & $\mathbf{P}$ & 5 & $\mathbf{P}$ & & & 0 \\
\hline $\begin{array}{l}\text { Spongotrochus } \\
\text { glacialis }\end{array}$ & 5 & $\mathbf{P}$ & 5 & 10 & $\mathbf{P}$ & $\mathbf{P}$ & 5 & 0 \\
\hline $\begin{array}{l}\text { Spongurus } \\
\text { pylomaticus }\end{array}$ & & & & $\mathbf{P}$ & $\mathbf{P}$ & $\mathbf{P}$ & A & 0 \\
\hline Spongurus spp. & 5 & $\mathbf{P}$ & $\mathbf{P}$ & $\mathbf{P}$ & $\mathbf{P}$ & A & 10 & $>100$ \\
\hline $\begin{array}{l}\text { Stichopilium } \\
\text { bicorne }\end{array}$ & $\mathbf{P}$ & $\mathbf{P}$ & $\mathbf{P}$ & $\mathbf{P}$ & & & & \\
\hline Stylatractus spp. & & $\mathbf{P}$ & 5 & 5 & $\mathbf{P}$ & & & \\
\hline $\begin{array}{l}\text { Stylochlamydium } \\
\text { asteriscus }\end{array}$ & $\mathbf{P}$ & $\mathbf{P}$ & $\mathbf{P}$ & 5 & $\mathbf{P}$ & & & \\
\hline $\begin{array}{l}\text { Stylodictya } \\
\text { aculeata }\end{array}$ & & & & $\mathbf{P}$ & $\mathbf{P}$ & 5 & 5 & \\
\hline$\frac{\text { Stylodictya }}{\text { multispina }}$ & 5 & 5 & 5 & 10 & 10 & & & \\
\hline
\end{tabular}




\begin{tabular}{|c|c|c|c|c|c|c|c|c|}
\hline$\frac{\text { Stylosphaera }}{\text { melpomene }}$ & $\mathbf{P}$ & $\mathbf{P}$ & $\mathbf{P}$ & $\mathbf{P}$ & & & & \\
\hline $\begin{array}{l}\text { Styptosphaera } \\
\text { spumacea }\end{array}$ & $\mathbf{P}$ & $\mathbf{P}$ & $\mathbf{P}$ & $\mathbf{P}$ & & & & \\
\hline $\begin{array}{l}\text { Tetraplecta } \\
\text { pinigera }\end{array}$ & $\mathbf{P}$ & $\mathbf{P}$ & $\mathbf{P}$ & $\mathbf{P}$ & & & & \\
\hline $\begin{array}{l}\text { Thecosphaera } \\
\text { inermis }\end{array}$ & $\mathbf{P}$ & $\mathbf{P}$ & $\mathbf{P}$ & A & A & & & \\
\hline \begin{tabular}{|l} 
Theocorythium \\
trachelium
\end{tabular} & $\mathbf{P}$ & $\mathbf{P}$ & $\mathbf{P}$ & $\mathbf{P}$ & 5 & & & 0 \\
\hline \begin{tabular}{|l} 
Theopilium \\
tricostatum
\end{tabular} & $\mathbf{P}$ & $\mathbf{P}$ & $\mathbf{P}$ & 5 & $\mathbf{P}$ & $\mathbf{P}$ & $\mathbf{P}$ & 0 \\
\hline $\begin{array}{l}\text { Tholospyris } \\
\text { anthophora }\end{array}$ & & & $\mathbf{P}$ & $\mathbf{P}$ & $\mathbf{P}$ & & & \\
\hline $\begin{array}{l}\text { Tholospyris } \\
\text { ramosa }\end{array}$ & $\mathbf{P}$ & $\mathbf{P}$ & $\mathbf{P}$ & $\mathbf{P}$ & & & & \\
\hline$\frac{\text { Tholospyris }}{\text { tripodiscus }}$ & $\mathbf{P}$ & $\mathbf{P}$ & $\mathbf{P}$ & $\mathbf{P}$ & & & & \\
\hline $\begin{array}{l}\text { Tribonosphaera } \\
\text { centripetalis }\end{array}$ & & $\mathbf{P}$ & A & $\mathbf{P}$ & $\mathbf{P}$ & & & \\
\hline $\begin{array}{l}\text { Triceraspyris } \\
\text { antarctica }\end{array}$ & & & & & $\mathbf{P}$ & 5 & 10 & \\
\hline $\begin{array}{l}\text { Tricolocampe } \\
\text { cylindrica }\end{array}$ & $\mathbf{P}$ & $\mathbf{P}$ & $\mathbf{P}$ & $\mathbf{P}$ & & & & \\
\hline$\frac{\text { Trisulcus }}{\text { triacanthus }}$ & $\mathbf{P}$ & $\mathbf{P}$ & $\mathbf{P}$ & $\mathbf{P}$ & $\mathbf{P}$ & & & \\
\hline$\frac{\text { Zygocircus }}{\text { productus }}$ & $\mathbf{P}$ & $\mathbf{P}$ & 5 & $\mathbf{P}$ & $\mathbf{P}$ & & & \\
\hline
\end{tabular}

NOTE: Data included in the table and depicted in the distributional maps are approximate and based on very limited current knowledge or the corresponding ranges; further research will undoubtedly introduce substantial changes to many of these patterns. 
Figure 1A. Main features of a polycystine spumellarian cell. Slightly modified from Kling (1978) and Boltovskoy (1981e).

Figure 1B. Main features of a polycystine nassellarian cell. From Hollande and Enjumet (1960).

Figure 1C-E. General view of entire radiolarian colonies. C, D: by courtesy of Neil Swanberg (from Swanberg 1979); E: from Strelkov and Reshetnjak (1971).

Figure 2A. Characters used for the identification of spumellarian radiolarians. From Haeckel (1887).

Figure 2B, C. Characters used for the identification of spumellarian radiolarians. B: from Haeckel (1887); C: original.

Figure 2D, E. Characters used for the identification of spumellarian radiolarians. From Haeckel (1887).

Figure 2F. Characters used for the identification of spumellarian radiolarians. Original.

Figure 2G. Characters used for the identification of spumellarian radiolarians. From Haeckel (1887).

Figure $2 \mathrm{H}$, I. Characters used for the identification of spumellarian radiolarians. H: from Haeckel (1887); I: from Riedel (1958).

Figure 2J. Characters used for the identification of spumellarian radiolarians. Original..

Figure $2 \mathrm{~K}$. Characters used for the identification of spumellarian radiolarians. From Haeckel (1887).

Figure 2L, M. Characters used for the identification of spumellarian radiolarians. Original.

Figure 2N-S. Characters used for the identification of spumellarian radiolarians. M, P, Q: original; R: fom Nigrini and Moore (1979); N: from Dreyer (1889); O: from Petrushevskaya (1967); S: from Hollande and Enjumet (1960).

Figure 3A. Characters used for the identification of nassellarian radiolarians. From Petrushevskaya (1981).

Figure 3B, C. B: from Riedel (1958); C: from Petrushevskaya (1971a).

Figure 3D, E. Characters used for the identification of nassellarian radiolarians. From Petrushevskaya (1971a).

Figure 3F. Characters used for the identification of nassellarian radiolarians. From Haeckel (1887). 
Figure 3G. Characters used for the identification of nassellarian radiolarians. From Petrushevskaya (1971a).

Figure 3H-J. Characters used for the identification of nassellarian radiolarians. H: original; I, J: from Petrushevskaya (1971a).

Figure 3K, L. Characters used for the identification of nassellarian radiolarians. K: from Petrushevskaya (1971a); L: from Riedel (1957).

Figure 3M, N. Characters used for the identification of nassellarian radiolarians. M: from Petrushevskaya (1971a); N: from Petrushevskaya (1981).

Figure 3O, P. Characters used for the identification of nassellarian radiolarians. O: from Petrushevskaya (1971a); P: from Paverd (1995).

Figure 3Q, R. Characters used for the identification of nassellarian radiolarians. From Petrushevskaya (1971a).

Figure 3S-W. Characters used for the identification of nassellarian radiolarians. S, T, U, V: original; W: from Petrushevskaya (1971a).

Figure 4A. Comparison of the mean percentage abundances for several numerically dominant polycystine species recovered in 0-300 m plankton tows with those from time-series sediment traps deployed at $853 \mathrm{~m}$, in the eastern equatorial Atlantic. 1: Dictyocoryne profunda; 2: Spongodiscus resurgens; 3: Spongaster tetras; 4: Euchitonia elegans/furcata; 5: Stylochlamydium asteriscus; 6: Didymocyrtis tetrathalamus; 7: Spongotrochus glacialis; 8: Stylodictya multispina; 9: Arachnocorallium sp. (d) ; 10: Arachnocorallium sp. (a) ; 11: Arachnocorallium sp. (e) ; 12: Tetraplecta pinigera; 13: Cornutella profunda; 14: Dictyophimus gracilipes. From Boltovskoy et al. (1995).

Figure 4B. Comparison of the mean percentage abundances for several numerically dominant polycystine families and the two orders, recovered in 0-300 m plankton tows with those from time-series sediment traps deployed at $853 \mathrm{~m}$, in the eastern equatorial Atlantic. 1:

Spongodiscidae; 2: Pyloniidae; 3: Pyloniidae; 4: Litheliidae; 5: Coccodiscidae; 6:

Collosphaeridae; 7: Plagoniidae; 8: Theoperidae; 9: Pterocorythidae; 10: Pterocorythidae; 11: Cannobotryidae; 12: Artostrobiidae; 13: Spumellaria; 14: Nassellaria. From Boltovskoy et al. (1995).

Figure 5A, A'. Scanning electron microscope (left) and light-microscopy (right) photographs of the same radiolarian specimen, Cromyechinus antarctica. Notice that while SEM pictures yield great details of the surface of the shell-wall, they conceal all internal structures, most of which are important for identification purposes. From Boltovskoy (1981e), and Boltovskoy et al. (1983).

Figure 5B, B'. Scanning electron microscope (left) and light-microscopy (right) photographs of the same radiolarian specimen, Larcopyle butschlii. Notice that while SEM pictures yield great details of the surface of the shell-wall, they conceal all internal structures, most of which are 
important for identification purposes. From Boltovskoy (1981e), and Boltovskoy et al. (1983).

Figure 5C, C'. Scanning electron microscope (left) and light-microscopy (right) photographs of the same radiolarian specimen, Lithelius nautiloides. Notice that while SEM pictures yield great details of the surface of the shell-wall, they conceal all internal structures, most of which are important for identification purposes. From Boltovskoy (1981e), and Boltovskoy et al. (1983).

Figure 6. Schematic diagram of the mechanisms that can distort the sedimentary imprint of the planktonic pattern of fossilizable microplankton in general, and of polycystine radiolarians in particular (see text for detailed explanation). From Boltovskoy 1995.

Figure 7. Quantitative radiolarian distribution in the surface sedimentary layer of the South Atlantic. Redrawn from Goll and Bjørklund (1974).

Figure 8. Numbers of polycystine species reported in various surveys which presumably attempted to identify all members of this group in their samples (some figures are approximate). a: Benson 1966 (surface sediments from the Gulf of California); b: Renz 1976 (0-100 m plankton and surface sediments, selected satations); c: Boltovskoy and Riedel 1980 (0-1500 m plankton); d: Boltovskoy 1987 (surface sediments); e: Boltovskoy and Riedel 1987 (0-100 m plankton); f: Swanberg and Eide 1992 (0-400 m plankton); g: Boltovskoy et al. 1993a (sediment trap samples from $853 \mathrm{~m}$ ); h: Boltovskoy et al. 1996 (sediment trap samples from $2195 \mathrm{~m}$ ); i: Boltovskoy et al. 1995 (0-300 m plankton); j: Kling and Boltovskoy 1995 (0-2000 m plankton, selected samples); k: Paverd 1995 (5 m plankton); l: Welling 1990 (1000-1500 m sediment traps and surface sediments); m: Takahashi 1981 (400-5500 m sediment traps); n: Abelmann 1992 (300-2500 m sediment traps); o: Bjørklund 1973, and Swanberg and Bjørklund 1987 (0-1000 m fjord plankton samples and surface sediments); p: Abelmann and Gowing 1997 (0-1000 m vertically stratified plankton samples from 7 stations).

Figure 9. Fluctuations in polycystine numbers of species and specific diversity in surficial bottom sediments along a transect from the equator to the Antarctic in the south Pacific (based on data from Boltovskoy 1987).

Figure 10. Changes in the species richness and the equitability of radiolarian assemblages, as exemplified by single sample yields from an Equatorial area (from Boltovskoy 1987, surface sediments), a Transitional area (from data in Boltovskoy and Riedel 1987, 0-100 m plankton), and from the Antarctic (from data in Boltovskoy 1987, surface sediments).

Figure 11. Main biogeographic areas characterized by different radiolarian specific assemblages. Inset maps show the distribution of selected radiolarian species in surface sediments indicative of major biogeographic patterns (A, according to Goll and Bjørklund 1974); and Morley's (1977) biogeographic divisions of the South Atlantic based on the polycystine contents of 57 surface sediment samples (B).

Figure 12A, B. Vertical distribution patterns of polycystine radiolarians in various oceanic areas. In all cases total numbers of shells recorded are illustrated, which most probably significantly overestimates in situ living populations, especially below 100-200 m. From data in Kling and Boltovskoy (1995). 
Figure 12C-E. Vertical distribution patterns of polycystine radiolarians in various oceanic areas. In all cases total numbers of shells recorded are illustrated, which most probably significantly overestimates in situ living populations, especially below 100-200 m. From data in Renz (1976).

Figure $12 \mathrm{~F}, \mathrm{G}$. Vertical distribution patterns of polycystine radiolarians in various oceanic areas. In all cases total numbers of shells recorded are illustrated, which most probably significantly overestimates in situ living populations, especially below 100-200 m. From data in Boltovskoy and Alder (1992).

Figure 12H. Assumed proportions of live polycystine cells at various depths in the water column. From data in Kling and Boltovskoy (1995).

Figure 13. Schematic representation of the characteres used by Haeckel (1887) for the classification of the Sphaeroidea. 1: Ethmosphaerida; 2: Xiphostylida; 3: Staurostylida; 4: Hexastylida; 5: Coscinommida; 6: Carposphaerida; 7: Sphaerostylida; 8: Staurolonchida; 9: Hexalonchida; 10: Haliommida; 11: Thecosphaerida; 12: Amphistylida; 13: Stauracontida; 14: Hexacontida; 15: Actinommida; 16: Cromyosphaerida; 17: Cromyostylida; 18: Staurocromyda; 19: Hexacromyida; 20: Cromyommida; 21: Caryosphaerida; 22: Caryostylida; 23: Staurocaryda; 24: Hexacaryda; 25: Caryommida; 26: Plegmosphaerida; 27: Spongostylida; 28: Staurodorida; 29: Hexadorida; 30: Spongiommida.

Figure 14. Successive stages of growth of polycystine skeletons. From Petrushevskaya (1962, 1967).

Figure 15. Illustrations of polycystine species. Asterisks denote figures given with the original species description. Figure sources: from Benson (1966): 31b, 37a; from Bjørklund and Goll (1986), with kind permission from Elsevier Science: 129; from Boltovskoy and Jankilevich (1985), courtesy of Gauthier-Villar Editeur: 126a; from Boltovskoy and Riedel (1980): 28a, 28b, 82a, 110a; from Boltovskoy and Riedel (1987): 58a, 101a, 103a, 108a, 111a, 161a, 170a, 172a, 173a, 176a; from Boltovskoy and Vrba (1988): 60a, 62a; from Boltovskoy (1981e): 13b, 16a, 29b, 32b, 37b, 79b; from Boltovskoy (1987): 56b; from Caulet (1971): 157b; from Cheng and Yeh (1989): 96a; from Dumitrica (1988): 83a, 83b; from Goll (1972): 97a, 98; from Goll (1976): 93a, 93b, 94a, 100; from Goll (1980): 157a; from Haeckel (1887): 1-5, 6a, 7, 10, 16b, 17, 18c-e, 19b, 20, 31c, 34b, 40b, 47, 56a, 58b, 78b, 84b, 84c, 90b, 91, 92b, 112b, 115b, 116b, 117b, 119, 123d, 126b, 149b, 150b, 161b, 162b, 162c; from Hollande and Enjumet (1960): 42, 43b, 44b, 46b, 54, 55; from Kling (1977), with kind permission from Elsevier Science: 113b, 156a; from Kling (1978): 86a; from Matsuoka (1992), with kind permission from Elsevier Science: 69; from Matsuoka (1993): 166c; from Nigrini and Moore (1979): 19a, 22a; from Nigrini (1967), by courtesy of the Scripps Institution of Oceanography: 48a; from Nigrini (1968): 170c; from Nigrini (1971), by courtesy of Cambridge University Press: 71; from Paverd (1995): 14b, 15b, 18b, 57a, 90a, 136a, 141b, 147, 148b, 150a, 153b, 155b; from Petrushevskaya (1965): 171b, 171f, 173b, 174c, 175b, 176c; from Petrushevskaya (1967): 29c, 35b, 60c, 62c, 65c, 72b, 82b, $88 b, 89,94 b, 94 c, 104 c, 131 b, 131 c, 135 b, 163 b, 164 c, 165 b, 168 d, 167 b, 169 b$; from Petrushevskaya (1971a): 95b, 96b, 97b, 101b, 102, 103b, 103c, 106b, 107b, 108b, 109c, 110b, $111 \mathrm{~b}, 113 \mathrm{c}, 114 \mathrm{~b}, 120,122 \mathrm{~b}, 124 \mathrm{~b}, 125 \mathrm{~b}, 127 \mathrm{~b}, 128 \mathrm{~b}, 130 \mathrm{~b}, 133 \mathrm{~b}, 137 \mathrm{c}, 138 \mathrm{~b}, 139 \mathrm{~b}, 142 \mathrm{~b}$, 144b, 145c, 146b, 155c, 159b, 170d, 170e, 171e; from Petrushevskaya (1971c): 148a; from 
Petrushevskaya (1981): 172c, 172d; from Popofsky (1913): 25b, 26b, 41, 77; from Riedel (1958), by courtesy of the Mawson Antarctic Collection, University of Adelaide, Australia: 48c, 72a, 140b; from Schaaf (1981): 123c; from Strelkov and Reshetnjak (1971): 6b, 9, 21, 22b, 23b; Courtesy of Neil Swanberg (from Swanberg, 1979): 6c, 8, 11, 12; from Takahashi (1981): 40a; from Weinheimer (1994): 87b, 113a; Original: 13a, 14a, 15a, 18a, 19c, 23a, 23c, 24a, 25a, 25c, 26a, 27a-d, 29a, 30, 31a, 32a, 33a, 33b, 34a, 35a, 36, 37c, 38a, 38b, 39a-c, 43a, 44a, 44c, 45, 46a, 48b, 48d, 49-53, 57b, 57c, 59a-c, 60b, 60d, 61a, 61c, 62b, 63a-c, 64, 65a, 65b, 66, 67, 68a-c, 70a-c, 73-76, 77b, 77c, 78a, 79a, 80a-c, 81a, 81b, 82c, 84a, 84d, 85a-c, 86b, 87a, 87c, 87d, 88a, 88c, 89b, 90c, 92a, 95a, 97c, 99, 100b, 103d, 104a, 104b, 105a-d, 105f, 106a, 106c, 107a, 109a, 109b, 109d, 112a, 114a, 114c, 115a, 116a, 117a, 118a, 118b, 121, 122a, 123a, 123b, 124a, 125a, 127a, 128a, 130a, 131a, 132a, 132b, 133a, 134a, 134b, 135a-c, 137a, 137b, 138a, 139a, 140a, 141a, 141c, 142a, 143, 144a, 145a, 145b, 146a, 148c, 149a, 149c, 151a, 152a, 152b, 153a, 154, 155a, 155d, 156b, 157c, 158a-c, 159a, 160, 162a, 163a, 163c, 163d, 164a, 164b, 165a, 166a, 166b, 166d, 167a, 168a-c, 169a, 170b, 170f, 170g, 171a, 171c, 171d, 172b, 174a, 174b, 174d, 175a, 176b. 